UNIVERSIDADE DE SÃO P AULO

INSTITUTO DE RELAÇÕES INTERNACIONAIS

BARBARA FROSSARD PAGOTTO

\title{
A SAÚDE PÚBLICA COMO TEMA DE SEGURANÇA \\ INTERNACIONAL: O CASO DAS NEGOCIAÇÕES DO NOVO REGULAMENTO SANITÁRIO INTERNACIONAL \\ (RSI 2005)
}

São Paulo

2016 


\section{A SAÚdE PÚBLICA COMO TEMA DE SEGURANÇA INTERNACIONAL: O CASO DAS NEGOCIAÇÕES DO NOVO REGULAMENTO SANITÁRIO INTERNACIONAL \\ (RSI 2005)}

Dissertação apresentada ao Programa de Pós-Graduação em Relações Internacionais do Instituto de Relações Internacionais da Universidade de São Paulo, para obtenção do título de Mestre em Ciências

Orientadora: Prof. Deisy de Freitas Lima Ventura 
Autorizo a reprodução e divulgação total ou parcial deste trabalho, por qualquer meio convencional ou eletrônico, para fins de estudo e pesquisa, desde que citada a fonte.

Ficha catalográfica

Biblioteca do Instituto de Relações Internacionais

Pagotto, Barbara Frossard

A saúde pública como tema de segurança internacional: o caso das negociações do novo Regulamento Sanitário Internacional (RSI 2005)/ Barbara Frossard Pagotto. Orientadora Deisy de Freitas Lima Ventura. São Paulo, 2016. 65p

Dissertação de Mestrado, Universidade de São Paulo, 2016

1. Saúde Pública (Regulamentação). 2. Securitização. 3. Regulamento Sanitário Internacional 4. Direito Público Internacional. I. Ventura, Deisy de Freitas Lima. II. Título.

CDD 344.04 


\section{AGRADECIMENTOS}

Agradeço primeiramente a minha orientadora e professora Deisy de Freitas Lima Ventura por ter confiado à mim uma pesquisa desafiadora e extremamente relevante e por ter apoiado todos os projetos desenvolvidos ao longo desse Mestrado. Ao professor Olivier Dabène por ter me recebido no Observatoire Politique de l'Amérique Latine et des Caraïbes em Paris, onde realizei um estágio que muito contribuiu para o desenvolvimento desta pesquisa. Agradeço a minha família pelo indispensável apoio nesses anos de estudos. Aos meus queridos amigos, pesquisadores e companheiros de sala de aula: Rodrigo Araújo e Fernanda Perez Aguilar, com quem dividi incertezas e alegrias, e à Letícia Crozara, cujo apoio e companheirismo têm sido fundamental.

Esta pesquisa não teria sido possível também sem o apoio financeiro da Fundação de Amparo à Pesquisa do Estado de São Paulo (FAPESP), sem o qual seria impossível a dedicação integral à pesquisa, além de ter sido um incentivo à realização de um bom trabalho. 


\section{SUMÁRIO}

LISTA DE ABREVIAÇÕES E SIGLAS 5

LISTA DE QUADROS $\quad 6$

$\begin{array}{ll}\text { RESUMO } & 7\end{array}$

INTRODUÇÃO 8

1. A SECURITIZAÇÃO DA SAÚDE 11

1.1 Estudos de Segurança e a Teoria da Securitização 11

1.2 Saúde como tema de Segurança 19

1.3 OMS, Securitização e a revisão do RSI (2005) 27

2. O REGULAMENTO SANITÁRIO INTERNACIONAL (2005) 34

2.1 O processo de negociação (1995 - 2005) 34

2.2. O destravamento das negociações 43

2.3 As dimensões de segurança nas negociações do RSI 48

2.4 O novo RSI: um documento de segurança? $\quad 67$

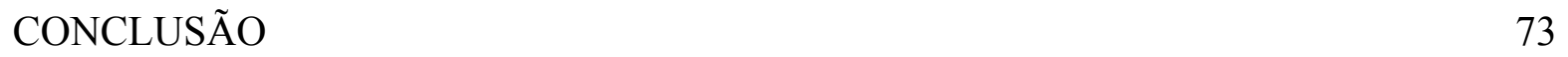

ANEXO I - Lista de entrevistados

ANEXO II - Questionários utilizados para a realização das entrevistas 76

$\begin{array}{ll}\text { Bibliografia } & 81\end{array}$ 


\section{LISTA DE ABREVIAÇÕES E SIGLAS}

AFRO - Escritório Regional Africano

AIEA - Agência Internacional de Energia Atômica

AMS - Assembleia Mundial da Saúde

AG - Assembleia Geral das Nações Unidas

CS - Conselho de Segurança

EMRO - Escritório Regional para o Mediterrâneo Oriental

ESPII - Emergência de saúde pública de importância internacional

EURO - Escritório Regional para Europa

GIT - Grupo Intergovernamental de Trabalho

IOM - Instituto de Medicina dos Estados Unidos

MINAUCE - Missão das Nações Unidas para Ação e Urgência contra o Ebola

OMS - Organização Mundial da Saúde

ONU- Organização das Nações Unidas

OPAS - Organização Pan-Americana de Saúde

RSI - Regulamento Sanitário internacional

SEARO - Escritório Regional para Sudeste Asiático

WPRO - Escritório Regional para Pacifico Ocidental 


\section{LISTA DE QUADROS}

QUADRO 1 - Cronologia das negociações/ Eventos internacionais/ Resoluções da OMS QUADRO 2 - Evolução dos artigos do RSI 


\title{
RESUMO
}

A negociação do novo Regulamento Sanitário Internacional (RSI) foi um processo complexo que durou dez anos e envolveu preocupações que extrapolam o campo da saúde pública. Este artigo, resultado final da pesquisa de Mestrado desenvolvida no âmbito do Programa de Pós-Graduação do Instituto de Relações Internacionais da Universidade de São Paulo (IRI/USP), busca demonstrar, por meio de vasta pesquisa documental, revisão de literatura e entrevistas com atores, que a agenda de segurança internacional influenciou as negociações do RSI em vigor, contribuindo para o avanço do processo de securitização da saúde pública. Temas de segurança internacional, notadamente o uso intencional ou acidental de agentes químicos, biológicos, radio-nucleares e a potencial ameaça de bioterrorismo foram determinantes tanto do avanço das negociações como da natureza do documento final aprovado, que promoveu mudanças substanciais na regulação internacional da saúde pública.

\begin{abstract}
The negotiation of the new International Health Regulations (IHR) was a complex 10-year-long process and involved concerns which go beyond the public health field. This article, the final result of the Master's program at the Institute of International Relations of the University of Sao Paulo (IRI/USP), aims to demonstrate, through vast documental research, literature review and interview with actors, how the international security agenda influenced the IHR negotiations, advancing the securitization process of public health. International security issues, specially the intentional or accidental use of biological, chemical or radio-nuclear agents and the potential threat of bioterrorism were determinant both for the negotiation advancement and the character of the approved final document, which promoted substantial changes in the international public health regulation.
\end{abstract}

Palavras-chave: Regulamento Sanitário Internacional ; segurança sanitária ; securitização International Health Regulations; health security; securitization 


\section{INTRODUÇÃO}

A resposta do Conselho de Segurança (CS) das Nações Unidas (ONU) à crise sanitária provocada pelo vírus Ebola é a mais recente manifestação de uma prática já consolidada de securitização da saúde pública no plano internacional. Em idênticas cartas enviadas ao Conselho de Segurança e à Assembleia Geral (AG) das Nações Unidas, o Secretário Geral da ONU, ao afirmar que a crise do Ebola não é apenas uma crise de saúde pública, mas sim uma crise multidimensional, com importantes dimensões políticas, sociais, econômicas, humanitária, logística e de segurança, anuncia a criação da primeira missão sanitária da ONU, a Missão das Nações Unidas para Ação e Urgência contra o Ebola (MINAUCE) ${ }^{1}$ (ONU, 2014b). No dia seguinte, em 18 de setembro de 2014, o CS aprova a resolução 2177, declarando a propagação sem precedentes da epidemia de Ebola na África uma « ameaça à paz e à segurança internacional » (ONU, 2014a), levando assim a segurança sanitária global ao topo das agendas de saúde e segurança.

A resolução 2177 e a criação da MINAUCE são exemplos emblemáticos da crescente securitização da resposta às crises sanitárias, entendendo-se por securitização o processo pelo qual os temas de saúde são socialmente construídos como ameaça à segurança, o que legitima a adoção de medidas excepcionais em caráter de urgência (BUZAN; WAEVER; WILDE, 1998, p 24). Essas iniciativas podem ser analisadas a partir de duas perspectivas diversas mas inter-relacionadas: a evolução da concepção de segurança internacional e a percepção de doenças infecciosas como ameaça (BURCI, 2015, p.31). A relação entre saúde e segurança não é recente, visto que a própria Constituição da Organização Mundial da Saúde (OMS) faz menção à importância do direito à saúde para o alcance da paz e segurança (OMS, 1946). Essa conexão, contudo, passa a ser efetivamente explorada, tanto no campo de saúde quanto no de segurança, a partir da década de 1990 (MCINNES, KELLE, 2006; DAVIES 2008; FIDLER 2003), com a paulatina construção política da noção de « segurança sanitária global » que parece afirmar-se definitivamente no léxico das organizações internacionais, dos governos e da academia durante a crise do Ebola.

A importância crescente do enfoque da saúde a partir da perspectiva de segurança tem dividido opiniões, sobretudo pelo fato de a securitização ter o potencial de transformar respostas a questões sanitárias em políticas de segurança, o que legitima a adoção de medidas excepcionais

\footnotetext{
${ }^{1}$ A criação dessa missão sanitária teve o aval da Assembleia Geral por meio da resolução 69/1 (ONU, $\left.2014 b\right)$.
} 
cujas repercussões extrapolam o campo da saúde pública.

A tensão entre as perspectivas de saúde e segurança caracterizou as negociações do Regulamento Sanitário Internacional, principal instrumento jurídico vinculante da OMS, adotado em virtude do artigo 21 da carta constitutiva da Organização ${ }^{2}$, que visa a construir uma vigilância global contra a propagação internacional de doenças. Além de o atual RSI trazer uma nova abordagem para controle de doenças, que diverge em grande medida dos regulamentos anteriores ${ }^{3}$, seu processo de negociação durou dez anos e foi marcado por acirradas discussões em torno da interferência de interesses de segurança num documento de saúde pública. Esses debates são alavancados sobretudo após os atentados de 11 de setembro de 2001 em Nova Iorque, e os subsequentes envios de postais contaminados com antraz (anthrax) ${ }^{4}$, eventos que trouxeram para o centro da negociação preocupações de biossegurança e bioterrorismo.

O RSI, adotado pela Assembleia Mundial da Saúde (AMS), em maio 2005, por meio da resolução 58.3 (OMS, 2005), é mais do que um tratado de cooperação internacional de combate à propagação de doenças, trata-se de um complexo mecanismo que insere numa mesma estrutura objetivos de saúde pública e interesses de segurança. O atual RSI integra o conjunto de mecanismos de governança global da saúde, sendo um importante aparato legal que consolida os esforços de securitização da saúde pública como um aspecto permanente dessa governança. Atualmente, ele está em vigor em 196 Estados, dois a mais dos que compõem a OMS 5 .

Para entender a complexidade desse Regulamento e como ele se enquadra em um processo mais amplo de securitização da saúde, foi desenvolvida uma pesquisa sobre o processo de revisão do RSI, com o objetivo de analisar em que medida temas de segurança internacional, como a utilização de agentes de armas de destruição em massa e o bioterrorismo, influenciaram as negociações. Para isso, uma extensa revisão de literatura sobre o tema, pesquisa documental no banco de dados

\footnotetext{
${ }^{2} \mathrm{O}$ artigo 21 da Constituição da OMS atribui à Assembleia Mundial da Saúde a competência para adotar regulamentos concernentes a questões sanitárias e demais procedimentos designados a prevenir a propagação internacional de doenças (OMS, 1946)

3 Desde sua criação, em 1946, a OMS adotou três Regulamentos Sanitários Internacionais: em 1951, 1969 (atualizado em 1981) e em 2005.

${ }^{4}$ Em setembro de 2001, esporos de antraz foram enviados para várias localidades via serviço postal. Isso resultou em vinte e dois casos confirmados ou suspeitos de infecção por antraz. Onze destes foram casos inalatórios, dos quais cinco morreram; onze foram casos cutâneos (sete confirmados e quatro suspeitos) (INGLESBY, T. et al. 2002)

5 Os Estados-Partes do RSI podem ser consultados no site da OMS: http://www.who.int/ihr/legal issues/states parties/ en/ . (acessado em 19 de julho de 2016). Os Estados Partes do RSI que não fazem parte da OMS são: Santa Sé e Liechtenstein
} 
da $\mathrm{OMS}^{6}$ e entrevistas com alguns membros das delegações dos Estados negociadores do $\mathrm{RSI}^{7}$ foram realizadas. As informações obtidas por meio das entrevistas corroboram as hipóteses suscitadas com base na pesquisa documental de que os interesses de segurança permearam as negociações, influenciando os dispositivos do documento final. Ademais, a pesquisa demonstra que, ao longo do processo de revisão, o Secretariado da OMS não esteve inerte a essa influência, desempenhando um papel securitizador, ao promover seu paradigma de segurança sanitária mundial.

Este artigo apresenta os resultados dessa pesquisa em duas partes: a primeira mais conceitual, em que se aborda, de forma panorâmica, as teorias de segurança, a securitização da saúde e o papel da OMS nesse processo; e a segunda parte dedicada ao processo de negociação do RSI e à análise dos dispositivos mais polêmicos que evidenciam a tensão entre saúde e segurança ao longo do processo de revisão.

Concluímos que não só interesses de segurança influenciaram intensamente as negociações e o conteúdo normativo do atual Regulamento, como a revisão do RSI foi favorecida por um discurso de segurança, promovido pela OMS, sobretudo a partir de 2001, quando os ataques terroristas, seguidos dos ataques de antraz, projetaram o bioterrorismo e a biossegurança nas agendas internacionais. Esses eventos chamam a atenção dos Estados para a importância do documento que estava sendo negociado, concebido como instrumento coletivo de segurança sanitária global, o que favorece o avanço das negociações. Não obstante, a perspectiva de segurança trouxe uma nova dinâmica ao processo de revisão, tornando-o controverso e polarizado, o que dificultou a obtenção de um consenso sobre um documento final antes de 2005.

\footnotetext{
${ }^{6}$ O Banco de dados Online da OMS, Institutional Repository for Information Sharing (IRIS), pode ser acessado na página: http://apps.who.int/iris/

${ }^{7}$ A lista dos entrevistados, a metodologia utilizada na condução das entrevistas, bem como os questionários aplicados, estão descritos no Anexo.
} 


\section{A SECURITIZAÇÃO DA SAÚDE}

A securitização da saúde pública é um fenômeno relativamente recente que tem fomentado um vasto campo de estudos. Mudanças sofridas tanto no campo da saúde quanto nos estudos de segurança impulsionaram a interconexão entre essas duas áreas, que por muito tempo estiveram segregadas, levando a saúde pública a ocupar um novo espaço nas agendas de política internacional. Para compreender esse fenômeno, esta primeira parte está subdividida em três seções. Primeiramente serão apresentados alguns estudos de segurança, com destaque para a teoria de securitização da Escola de Copenhague; a segunda seção será dedicada à construção do nexo saúdesegurança e ao conceito de segurança sanitária; e, na última seção, abordaremos o papel desempenhado pela OMS no processo de securitização da saúde pública no período que compreende as negociações do Regulamento.

\subsection{Estudos de Segurança e a Teoria da Securitização}

Desde o surgimento de Relações Internacionais como disciplina acadêmica, a partir da Primeira Guerra Mundial, o tema de segurança nacional tem ocupado o centro do debate. Dentre a vasta literatura que surge nesse momento, voltada a compreender e prever o comportamento do Estado no ambiente internacional, a escola Realista ganha proeminência, dominando os estudos se segurança na maior parte do século XX.

A perspectiva teórica realista ${ }^{8}$ embasou uma concepção de segurança fundamentada numa objetiva representação da realidade, em que os principais atores são os Estados, os quais agem racionalmente, buscando garantir sua sobrevivência e integridade territorial frente às ameaças externas. Essa visão de segurança, considerada como a teoria tradicional ou ortodoxa, terá seus pressupostos questionados com o surgimento de novas abordagens teóricas, a partir da década de 1980, que desafiam a estrutura tradicional dos estudos estratégicos de segurança, calcada no Estado e no militarismo, e propõem uma concepção alternativa de segurança. Os trabalhos de Richard Ulman's Redefining Security (1983), Jessica Mathews Redefining Security (1989) e Barry Buzan People, States and Fear (1983) são referência nesse debate emergente.

\footnotetext{
${ }^{8}$ Destacam-se como estudos pioneiros da escola Realista de Relações Internacionais a obra de Edward Carr, « Vinte Anos de Crise » publicado em 1939 e de Hans Morgenthau «A Política entre as Nações » de 1948.
} 
Os novos estudos que surgem no campo de segurança contemplam outros níveis de análise para além do Estado, trazendo uma perspectiva crítica que realça os processos por meio dos quais indivíduos, coletividades e ameaças são construídos como « fatos sociais » e a influência de tais construções nas questões de segurança (KRAUSE; WILLIAMS, 1996, p.242). Nesse sentido, percebe-se que não há uma definição universalmente aceita para o termo « segurança », este permanece como «um conceito essencialmente contestado » (BUZAN, 1983, p. 10) que continua a gerar muitas perguntas e respostas.

A emergência da concepção de "segurança humana » nesse contexto, com o relatório do Programa das Nações Unidas para Desenvolvimento sobre desenvolvimento humano, em 1994, ilustra o debate em torno de um novo entendimento para segurança e da reconfiguração do seu escopo (PNUD, 1994). O conceito de segurança humana propõe uma mudança de foco do Estado para o indivíduo, colocando a origem das ameaças nas inseguranças diárias sofridas pelos indivíduo no cotidiano. As ameaças assumem, assim, naturezas diversas, seja econômica, alimentar, sanitária, pessoal, comunitária ou política, trazendo para o centro do debate questões relacionadas à dignidade humana e ao modo de vida em sociedade. Nessa perspectiva, a segurança humana é entendida como « liberdade do medo » (freedom from fear) e «liberdade de querer » (freedom from want) (PNUD, 1994, p. 24).

O cerne da segurança humana representa, portanto, duas grandes mudanças: a alteração do objeto referente, passando do Estado para o indivíduo, e o reconhecimento de um campo mais amplo de ameaças. Utilizar a segurança humana como categoria analítica evidencia que, a depender do objeto referente adotado, qualquer tema relacionado ao desenvolvimento humano pode potencialmente ser um problema securitário, o que transforma a definição de segurança em um conceito allinclusive e acaba por esvaziar o seu próprio conteúdo, tornando-o analítica e politicamente inoperável (WAEVER, 1995, p. 48).

Apesar de a abordagem de segurança humana ter uma utilidade inegável de policy-making agenda, uma utilidade normativa, ela carece, contudo, de uma estrutura de análise de políticas de segurança (FLOYD, 2007, p. 39). Nessa perspectiva, a ampliação do entendimento de segurança e do rol de ameaças possíveis traz a necessidade de mecanismos e ferramentas analíticas que possibilitem constatar o fenômeno da securitização, ou seja, como as ameaças são construídas e como novos temas são inseridos na lógica de segurança.

Uma das abordagens de segurança que ganha proeminência na década de 1990, fornecendo uma estrutura teórica para compreender a construção política de segurança são os estudos do que 
ficou conhecido como Escola de Copenhague ${ }^{9}$, que se desenvolveu com base, sobretudo, nos estudos de Barry Buzan (1983; 1998) e Ole Waever (1995). Dentre os principais aportes teóricos trazidos pela Escola de Copenhague, o conceito de « securitização » - formulado por Ole Waever (1995) e desenvolvido em 1998 na obra Security: A New Framework for Analysis - é essencial à redefinição de segurança proposta e para ampliação de sua agenda.

« 'Segurança' é o movimento que trata a política para além das regras estabelecidas do jogo e enquadra os temas ou como um tipo especial de política ou como algo acima da política »(BUZAN; WAEVER; WILDE, 1998, p.23, tradução nossa ${ }^{10}$ ). Esse movimento é promovido pela securitização, sendo esta entendida como o processo pelo qual problemas de segurança são socialmente construídos: « temas de segurança tornam-se temas de segurança por meio de atos de securitização $»^{11}$ (Ibid., p.24, tradução nossa). Waever (1995) compreende a securitização como um « ato de fala » - speech act -, ou seja, é a construção discursiva de um objeto referente como relativo ao campo de segurança. Nomear algo como segurança é atribuir um significado político particular a determinado tema, conferindo-lhe tratamento prioritário, por via da emergência e da excepcionalidade, o que justifica a utilização de medidas extraordinárias que desconsideram as regras do jogo político normal (Ibid., p. 24).

A teoria de securitização de Copenhague destaca, portanto, o papel da linguagem, do discurso, na construção de ameaças à segurança, com ênfase na natureza performativa da linguagem, com base na teoria de John Austin do « ato de fala » (1962). Nessa construção teórica, o próprio ato de fala cria a segurança, conforme Waever argumenta: « a declaração é em si mesma o ato. Ao falar, algo acontece (...). Ao declarar « segurança » um representante do Estado transfere um desenvolvimento particular para uma área específica, e assim, reivindica um direito especial de utilizar quaisquer meios necessários para bloqueá-lo» ${ }^{12}(1995$, p.55, tradução nossa).

O discurso é o mecanismo desencadeador do processo de securitização. Todavia, para que

\footnotetext{
${ }^{9} \mathrm{O}$ nome « Escola de Copenhague » foi cunhado por Bill McSweeney em ensaio critico: « Identity and security: Buzan and the Copenhagen school» na Review of International Studies em 1996. A Escola de Copenhague é geralmente utilizada para se referir aos primeiros trabalhos realizados desde 1985 pelo grupo de pesquisa European Security do Copenhagen Peace Research Institute (WAEVER, 2004, p.6)

${ }^{10}$ Traduzido do inglês: « Security is the move that take politics beyond the established rules of the game and frames the issues either as a special kind of politics or as above politics »

11 Traduzido do inglês: « Security issues are made security issues by acts of securitization »

12 Traduzido do inglês: « the utterance itself is the act. By saying it, something is done (...). By uttering 'security' a state-representative moves a particular development into a specific area, and thereby claims a special right to use whatever means necessary to block it »
} 
esse discurso possa produzir os efeitos desejados, ele deve ser proferido por um « ator securitizador », o agente que declara ameaçada a existência de determinado " objeto referente », reivindicando a necessidade e o direito de utilizar medidas extraordinárias para enfrentar a ameaça em questão (BUZAN; WAEVER; WILDE, 1998, p. 26). Esse papel tem sido tradicionalmente desempenhado por líderes políticos, burocratas e grupos de pressão, e, em princípio, esses atores podem tentar construir qualquer tema como ameaça. O objeto referente é aquilo que é percebido como tendo sua existência ameaçada e que, portanto, tem a legitimidade de reivindicar sua sobrevivência ${ }^{13}$. Quando esse ator securitizador, por meio do discurso, apresenta uma ameaça à existência de um determinado objeto referente, está ocorrendo um « movimento securitizante », mas, para que ocorra efetivamente a securitização, é necessário que esse discurso seja recepcionado e socialmente aceito por uma audiência (Ibid., p. 25).

Destaca-se que não é necessário que o discurso mencione a palavra « segurança », que exista uma real ameaça ou que medidas emergenciais sejam implementadas. $\mathrm{O}$ que é essencial para haver uma ação securitizadora é a prática discursiva apresentando uma ameaça à existência de um objeto referente e que esse discurso ganhe efetiva ressonância na audiência para que esta legitime a utilização de medidas de emergência, caso estas sejam adotadas:

(...) quando um ator securitizador utiliza a retórica de uma ameaça existencial e assim retira um tema do que é, sob essas condições, a " política normal », nós temos um caso de securitização. Dessa forma, a exata definição e os critérios da securitização são constituídos pelo estabelecimento intersubjetivo de uma ameaça existencial com importância suficiente para ter efeitos políticos substanciais (BUZAN; WAEVER; WILDE, 1998, p. 24-25, tradução nossa) $)^{14}$

Para um ato de fala ser bem sucedido e produzir os efeitos esperados, é fundamental uma relação entre linguagem e sociedade, ou seja, uma combinação entre características intrínsecas do ato de fala e o grupo que autoriza e reconhece o discurso, por isso existem « condições facilitadoras » de um ato de fala securitizador, condições que possibilitam a securitização por meio do discurso. As três principais condições são: a demanda interna ao ato de fala, este deve seguir

\footnotetext{
${ }^{13}$ Nas teorias de segurança, o objeto ameaçado tem sido tradicionalmente o Estado, mas a teoria de securitização apresenta uma possibilidade mais ampla de definição do objeto referente, visto que atores securitizadores podem construir qualquer coisa como objeto referente ameaçado e que uma posição centrada no Estado é possível, mas não está pré-determinada. «We do not say that security is about the state (...) nor that security is equally available to all » (BUZAN; WAEVER; WILDE; 1998, p. 37). Os autores enfatizam seu foco, no entanto, nas coletividades (Ibid, p.35).

14 Traduzido do inglês: « (...) when a securitizing actor uses a rhetoric of existential threat and thereby takes an issue out of what under those conditions is 'normal politics', we have a case of securitization. Thus, the exact definition and criteria of securitization is constituted by the intersubjective establishment of an existential threat with a saliency sufficient to have substantial political effects »
} 
uma gramática de segurança; as condições sociais em relação à posição de autoridade do ator securitizador - a relação entre o enunciador e a audiência; e as características das supostas ameaças, o que pode facilitar o impedir a securitização ${ }^{15}$ (Ibid, p. 33).

O ato de securitização é, portanto, um processo intersubjetivo e socialmente construído, é um ato negociado entre o ator securitizador e a audiência, que possibilita retirar um tema do jogo político normal, e inseri-lo no campo da excepcionalidade. Compreender esse processo significa « compreender o processo de construção de um entendimento compartilhado do que é para ser considerado e respondido coletivamente como uma ameaça ${ }^{16}{ }^{16}$ BUZAN; WAEVER; WILDE, 1998, p. 26, tradução nossa). Securitizar um tema é sempre uma escolha política e que gera consequências, uma vez que securitização fará com que atores ajam de modo diferente do que atuariam em outras circunstâncias (Ibid., p.32).

Não obstante as contribuições da teoria da securitização, esta não está isenta a críticas. No entanto, considerando a finalidade e a limitação temporal desta pesquisa, não será realizada uma análise ampla e detalhada de todas os estudos de segurança, nem de todas as críticas aferidas à teoria de securitização. São destacadas apenas algumas proposições teóricas alternativas à Copenhague e argumentos críticos de outros estudos que consideramos pertinentes para compreender o processo de securitização da saúde e o papel das negociações do Regulamento Sanitário Internacional nesse contexto.

A concepção de segurança trazida por Balzacq em The Three Faces of Securitization: Political Agency, Audience and Context (2005) apresenta algumas premissas para uma efetiva securitização que destoam da abordagem teórica de Buzan e Waever. Balzacq argumenta que a perspectiva de segurança baseada no ato de fala é muito formalista e não fornece os fundamentos adequados para examinar os fenômenos de segurança nas situações reais, de modo que se torna necessário acrescentar novas variáveis para refinar o entendimento da teoria.

Nessa perspectiva, o autor destaca que a teoria da securitização de Copenhague não confere a devida relevância ao papel do contexto e reduz a securitização a um procedimento convencional, a um « código de prática ». A teoria de securitização, segundo o autor, busca estabelecer princípios universais de comunicação, que tendem a ser funcionais independentemente do contexto, cultura e do poder relativo dos atores (BALZACQ, 2005, p. 172).

\footnotetext{
${ }^{15}$ Buzan, Waever e Wilde argumentam que é mais provável que um ator invoque uma ameaça à segurança se determinado objeto é normalmente visto como ameaçado por determinado tema (1998, p.33).

${ }^{16}$ Traduzido do inglês: « is to understand the process of constructing a shared understanding of what is to be considered and collectively responded to as a threat»
} 
Balzacq concorda que o conceito de segurança modifica o contexto, conforme defendido pelos teóricos de Copenhague; contudo, para ganhar a audiência e produzir os efeitos desejados, os discursos de segurança devem estar alinhados ao contexto externo (Ibid., p.182). Segundo o autor, a securitização deve ser entendida como uma prática estratégica e pragmática que ocorre na configuração de circunstâncias, e como parte desta, inclui o contexto, a disposição psico-cultural da audiência e o poder que tanto o enunciador quanto o ouvinte trazem para a interação (Ibid., p. 172). Toda securitização é um processo histórico que ocorre entre um conjunto influente de eventos anteriores e os seus impactos nas interações (BALZACQ, 2005, p. 193).

Compreender a securitização como uma prática estratégica permite enfatizar o contexto e os aspectos não-linguísticos que podem influenciar a securitização, bem como considerar outros fatores, como as capacidades dos agentes e o campo social em que o jogo retórico ocorre. Para Balzacq, a Escola de Copenhague, ao promover a análise do discurso como ferramenta de pesquisa para segurança, ignora o poder do contexto como uma variável explicativa na eficácia da linguagem. Mcinnes e Ruston (2012), ao analisar o processo de securitização do HIV/AIDS, demonstramse, em termos teóricos, mais alinhados às críticas formuladas por Balzacq à teoria da Escola de Copenhague, apesar de os autores não se proporem a aplicar os argumentos do autor ao caso do HIV/ AIDS.

Os Estudos Críticos de Segurança (ECS) também oferecem um enfoque alternativo à Escola de Copenhague e alcançam grande repercussão no campo dos estudos de segurança. A abordagem crítica leva a repensar o senso comum da ortodoxia realista, ao desafiar os estudos convencionais de segurança, partindo-se da perspectiva de que diferentes teorias políticas produzem diferentes conceitos de segurança. Isso implica compreender «segurança » como um « conceito derivado », pois a forma como esta é definida não pode ser desvinculada das teorias políticas que sustentam esse conceito (BOOTH, 2004, p. 13).

Os estudos críticos avançam no questionamento dos pressupostos realistas, como seu Estadocentrismo, trazendo para campo da segurança outros referentes, sobretudo o indivíduo e coletividades, a quem é dada a primazia tanto na definição das ameaças quanto na definição de quem ou o que deve ser assegurado (KRAUSE; WILLIAMS, 1997, p. 43). Destacam-se os estudos emancipatórios de segurança - também denominado de « Escola Galesa » (Welsh School) (WAEVER, 2004, p. 8) -, que têm como referência os trabalhos de Ken Booth e de Richard Wyn Jones.

Para a teoria da segurança como emancipação, o significado de segurança não decorre de princípios universais que devem ser protegidos, mais sim das experiências reais de inseguranças 
resultante das condições de vida das pessoas (BOOTH, 2007, p. 101). Segurança está vinculada à experiência de sentir-se inseguro: «As pessoas entendem o que é segurança ao saber como é se sentir seguro» ${ }^{17}$ (Ibid, p. 101). Booth define segurança como o fim das restrições que recaem sobre a vida dos indivíduos e grupos, retirando-os das estruturas opressoras que os impedem de fazer suas escolhas de forma livre. Essas opressões ou ameaças podem ir da violência direta contra o corpo humano - como conflitos, formas de opressão decorrentes de estruturas políticas e econômicas - até as ameaças à identidade (NUNES, 2013, p. 8). « Segurança na política mundial é um valor instrumental que confere às pessoas alguma oportunidade de escolher como viver. É um meio pelo qual indivíduos e coletividades podem investir e reinventar diferentes ideias sobre ser humano ${ }^{18}$ (BOOTH, 2004, p. 23). Mais segurança, portanto, não significa o aumento de medidas draconianas ou extraordinárias, mas sim o alívio das inseguranças que são experimentadas pelos indivíduos e grupos todos os dias (NUNES, 2013, p. 8).

Em Paris, houve um desenvolvimento particular de estudos de segurança, inspirado, em grande medida, nos trabalhos de Bourdieu e Foucault e que analisa segurança por meio de investigações empíricas, de práticas correntes de diversas agências, as quais revelam padrões e processos diferentes daqueles encontrados pelo estudo dos discursos (WAEVER, 2004, p.8). Didier Bigo e Jef Huysmans são autores de referência do que foi denominado « Escola de Paris » por Waever (Ibid).

Para a Escola de Paris, segurança deve ser analisada juntamente com o conhecimento institucional das agências, seus serviços e práticas - o que inclui também atos discursivos -, para entender como inimigos e adversários são socialmente construídos (Ibid). Essa abordagem está orientada, portanto, para a análise das atividades rotineiras das agências que levam à securitização e menos para o discurso, buscando mostrar como a insegurança é um produto, em grande medida, de políticas de segurança de diversas agências. (FLOYD, 2006, p.8). Segurança é um « deliberado processo de 'securitização/insecuritização' das fronteiras, identidades e da concepção de ordens. Securitização é a capacidade de criar insegurança» (BIGO, 2000, p. 173)

Assim, são diversas as abordagens teóricas que emergem, sobretudo a partir da década de 1990, buscando redefinir segurança, compreender como ameaças são construídas e analisar a ampliação da agenda securitária. Em relação à temática de saúde pública, a teoria da securitização da Escola de Copenhague tem sido uma importante ferramenta analítica, sendo utilizada em vários

\footnotetext{
17 Traduzido do inglês: « People understand what security is by knowing how security feels »

18 Traduzido do inglês: « Security in world politics is an instrumental value that enables people some opportunity to choose how to live. It is a means by which individuals and collectivities can invest and reinvent different ideas about being human »
} 
estudos voltados a compreender como temas de saúde são inseridos nas agendas de segurança (MCINNES; RUSHTON，2012; HANRIEDER; KREUDER-SONNEN，2014; ELBE， 2010: KELLE, 2007).

Tendo em vista o objeto de estudo desta pesquisa, a teoria de securitização constitui um importante arcabouço teórico para analisar a construção da saúde como segurança, sobretudo no âmbito da OMS, em que a vinculação do RSI a um discurso de segurança foi fundamental ao processo de revisão do Regulamento. A pesquisa, no entanto, valoriza outros fatores, não centrais à teoria de Copenhague, mas que consideramos relevantes para entender o processo de securitização da saúde e o papel do RSI nesse âmbito, notadamente a importância do contexto político e histórico em que se inserem as negociações. Para a Escola de Copenhague, o contexto do ato de securitização é definido de forma restrita ao momento da intervenção do ato de fala, e a possibilidade de a securitização ser construída ao longo do tempo, através de um conjunto de processo e representações, não é desenvolvida (MCDONALD, 2008, p. 2).

Consideramos que o contexto histórico desempenhou um papel fundamental do longo do processo de revisão do RSI. Corrobora essa premissa o fato de a iniciativa de revisão ocorrer em uma conjuntura internacional marcada pela emergência de novas doenças infecciosas, que são logo enquadradas como ameaças não tradicionais à segurança, e as negociações avançarem após determinados eventos internacionais que colocam em foco a relevância dos sistemas de saúde para estratégias de defesa e segurança dos países.

Embora a saúde tenha sido socialmente construída como um tema de segurança, esse processo de securitização não está desvinculado de considerações empíricas e nem se restringe ao discurso (MCINNES; RUSHTON 2012, p.120). Nesse sentido, os pressupostos teóricos de Balzacq (2005), sobretudo a ênfase no aspecto contextual da securitização, combinados ao arcabouço teórico de Copenhague, demonstram-se bastante pertinentes para compreender a importância da securitização da saúde no processo de revisão do RSI. 


\subsection{Saúde como tema de Segurança}

A saúde e a segurança são temas que por muito tempo estiveram separados, sobretudo por representarem áreas com interesses, ideologias e instituições distintas: enquanto os estudos de segurança estavam preocupados com a integridade territorial do Estado, sua capacidade militar e a possível eclosão de guerras, o campo da saúde estava voltado às oscilações na taxa de mortalidade, questões referentes à qualidade de vida e à busca de novos tratamentos para doenças. As duas áreas começam a, de fato, interagir quando há uma preocupação mútua, tanto em saúde pública quanto em segurança em relação à necessidade de responder efetivamente à propagação de doenças, um fenômeno que pode constituir, simultaneamente, uma crise sanitária e uma crise de segurança (ENEMARK, 2007, p.3).

Apesar de essa relação não ser nova, visto que a própria Constituição da OMS, em seu preâmbulo, vincula esse dois conceitos (OMS, 1946), pensar a saúde pública em termos de segurança, como uma questão política, é um fenômeno relativamente recente, que emerge na metade da década de 1990 (FIDLER, 2007, p.42). Até então, a saúde ocupava um papel restrito nas agendas de segurança, sendo analisada sob um viés militar, cujas preocupações centrais eram os impactos das doenças nas operações militares, a utilização de doenças infecciosas como arma de guerra e a repercussão dos conflitos nos serviços de saúde.

O fim da Guerra Fria, contudo, abriu espaço nos planos intelectual e político para considerar ameaças de natureza não militar que colocam em risco não só a segurança do Estado mas também a do indivíduo. O relatório do PNUD de 1994, apesar de ter sido desenvolvido para uma audiência voltada para políticas de desenvolvimento, tornou-se um documento marco dos parâmetros iniciais para o nascente campo de ameaças não tradicionais de segurança (LO YUK-PING; THOMAS, 2010, p. 448), visto que o conceito de segurança humana apresentado, ao tomar o indivíduo como objeto referente, expande substancialmente o rol de ameaças possíveis, conforme já apontado.

Nesse contexto, a securitização de temas de saúde encontra um terreno fértil, pois com o fim da Guerra Fria a audiência, sobretudo os Estados ocidentais, estava sensível à emergência de novos riscos à segurança nacional (MCINNES; 2015 p.7). Dessa forma, a interface entre as agendas de saúde e segurança amplia-se, o que contribui para o fenômeno caracterizado por Fidler de « revolução política » no campo da saúde pública: a saúde deixa de ser considerada um tema de low politics, e passa a constituir a esfera de high politics, ocupando cada vez mais espaço nas agendas de política externa e de segurança $(2010$, p.1). 
A projeção de temas de saúde na arena internacional é impulsionada, em grande medida, pela emergência de novas doenças infecciosas, a partir da década de 1980, com destaque para a propagação do HIV/AIDS e o ressurgimento de doenças como malária, tuberculose, meningite e dengue hemorrágica. A descoberta de, em média, quase uma nova doença por ano - tais como o Febre de Marburg, a Febre de Lassa e a Febre do Nilo Ocidental - provocou crescente preocupação nos países ocidentais, que logo enquadraram essas doenças infecciosas no arcabouço de « novas ameaças », passando a associá-las à segurança nacional (DAVIES, 2008, p. 306). Esse cenário cria as condições necessárias para a inserção de temas de saúde nas agendas de política externa e internacional, sob uma perspectiva securitizadora, processo esse favorecido pelo terror que as doenças infecciosas infligem nas pessoas, tanto o medo individual de contrair a infecção quanto o medo coletivo do contágio (ENEMARK, 2007, p. 9).

A securitização da saúde pública é normalmente analisada a partir três desenvolvimentos principais, que têm como foco as doenças infecciosas: o aumento da vulnerabilidade das populações à propagação dos riscos de doenças num mundo globalizado, o temor da proliferação de armas biológicas, sobretudo entre grupos terroristas, e a propagação global da epidemia do HIV/AIDS (DAVIES; KAMRADT-SCOTT; RUSHTON, 2015; RUSHTON 2011; FIDLER, 2007).

Tendo em vista o aumento do fluxo de comércio e de viagens internacionais a partir dos anos 1990, um surto de doença infecciosa em qualquer lugar do mundo é visto como uma ameaça em potencial para as demais populações, sobretudo num contexto de emergência de doenças infecciosas até então desconhecidas. A deflagração da epidemia de SARS, ao final de 2002, demonstra o impacto que o surgimento de um novo vírus pode ter num mundo globalizado carente de uma rede de vigilância e resposta sanitária organizada em escala mundial. Uma epidemia não implica apenas a devastação e sofrimento causados pela propagação de uma infecção, representa também a desorganização do Estado, seguida pelo descrédito do governo, com enfraquecimento das autoridades, das estruturas sociais e dos costumes (ZYLBERMAN, 2012, p.38).

A preocupação com as doenças infecciosas emergentes foi determinante para que a OMS reconhecesse a precariedade de seu sistema de vigilância e controle de doenças frente às deficiências do RSI de 1969 e buscasse redefinir sua rede de vigilância global de saúde. O melhor exemplo desse imperativo de resposta globalizada a emergências sanitárias foi a aceitação pela comunidade internacional da necessidade de revisão do RSI em 1995 (DAVIES; KAMRADTSCOTT, RUSHTON, 2015, p.2)

Um segundo desenvolvimento importante para o processo de securitização da saúde pública 
foi a possibilidade de agentes patogênicos serem utilizados como armas contra populações civis, seja por Estados ou por grupos terroristas, risco que ganha maior visibilidade no cenário internacional a partir da década de 1990, quando a existência de programas de armas biológicas na antiga União Soviética e no Iraque foi revelada (FIDLER, 2005, p. 341; DAVIS, 1999) e com os ataques de gás Sarin em Tóquio em $1995^{19}$.

Os ataques terroristas do 11 de setembro e os subsequentes ataques de antraz nos Estados Unidos, em 2001, redimensionaram essa problemática, pois indicaram o potencial risco de um ataque bioterrorista em escala global. O bioterrorismo, ao desfazer a distinção entre doenças infecciosas de causa natural e doenças decorrentes do uso intencional de agentes biológicos, insere ambas no mesmo arcabouço de segurança, reforçando, assim, o movimento de securitização da saúde pública (ABRAHAM, 2011, p. 806). Kelle aponta que os eventos de 2001 tiveram dois grandes efeitos: alteraram o equilíbrio entre o controle de armas químicas e a biodefesa ${ }^{20}$ em favor desta última, reduzindo a confiança no tradicional regime de controle de armas biológicas para lidar com a possibilidade de uma guerra biológica; e trouxeram para o debate o papel que a saúde pública deveria desempenhar no campo da segurança para enfrentar o bioterrorismo (2005; p. 25).

Para Enemark, o uso de armas biológicas contra alvos não militares é o ponto de partida para ultrapassar uma abordagem tradicional, que considera doenças infecciosas um problema de segurança apenas em situações de guerra e conflitos armados (2007, p.6). O tema de armas biológicas é o « gancho » que traz os surtos de doenças de causa natural para o campo da segurança, visto que os efeitos de um ataque biológico são similares aos de um evento natural de doenças infecciosas, e os recursos de saúde pública necessários para responder a tais incidentes são os mesmos. Isso permite que armas biológicas sejam « dessecuritizadas » como armas de destruição em massa e « ressecuritizadas » no campo da saúde pública (Ibid, p. 13).

A evolução das armas biológicas e a articulação deste tema com as doenças infecciosas de causa natural mudaram dramaticamente o relacionamento entre as áreas de segurança e saúde, tornando-as interdependentes: « a crescente percepção da ameaça de um ataque biológico transformou a saúde pública de um 'não-fator' no discurso de segurança a um recurso fundamental

\footnotetext{
19 «Em 1994, um ataque terrorista pela seita Aum Shinrikyo em Matsumoto, no Japão, utilizou sarin contra civis e acarretou a morte de 7 pessoas com 200 intoxicados que precisaram de cuidados médicos. Em 1995, um outro ataque terrorista com sarin pelo mesmo grupo no Japão, agora em Tóquio, provocou 5.000 vítimas, sendo 12 fatais imediatamente e várias outras ao longo de alguns anos ». (SILVA et al. 2012, p. 2084)

${ }^{20}$ Enquanto atividades biodefesa estavam voltadas, até então, para a proteção contra Estados que se utilizavam de armas biológicas, focando-se, portanto, na proteção de tropas no campo de batalha, essa abordagem não é mais válida em numa era de ameaças bioterroristas (KELLE, 2007, p. 218).
} 
para alcançar segurança nacional, interna e internacional contra armas biológicas ${ }^{21}$ (FIDLER; GOSTIN, 2007, p. 136, tradução nossa).

Dessa forma, o bioteorrismo, sobretudo a partir de 2001, ensejou respostas tanto na área de segurança como na de saúde pública no âmbito nacional e internacional. Nos Estados Unidos, em especial, a securitização da saúde pública foi motivada por iniciativas para combater o bioterrorismo, com a aprovação, por exemplo, do Public Health Security and Bioterrorism Preparedness and Response $A c t^{22}$, em 2002, que enquadra a prevenção, o preparo e a resposta a ataques bioterroristas como uma emergência de saúde pública. Nessa mesma perspectiva, destaca-se a iniciativa do G8 (G7 + México), logo após os ataques de 11 de setembro, em instituir a Global Health Security Initiative, que lançou o Ottawa plan for improving health security em novembro de 2011, embasado no argumento de que reforçar a capacidade global de vigilância e reposta a surtos de doenças é um componente essencial para a defesa contra um possível ataque de armas biológicas (OMS, 2003, p. 17).

Um terceiro fator que fomentou o aprofundamento da tendência securitizadora são as possíveis consequências sociais, econômicas e políticas, resultantes da propagação de doenças infecciosas, o que poderia impactar a estabilidade estatal e equilíbrio regional. Destaca-se, nesse aspecto, o caso da epidemia de HIV/AIDS, que, dentre as doenças infecciosas, foi considerada a primeira a aparecer, de fato, no radar de segurança dos Estados (ELBE; 2011; p 850), sendo objeto de uma extensa literatura sobre saúde e segurança (ELBE, 2006; MCINNES, 2006; MCINNES \& RUSHTON, 2012).

O HIV/AIDS foi concebido, inicialmente, como uma ameaça à segurança nacional, tendo em vista sua capacidade de afetar as estruturas vitais do Estado, notadamente as forças armadas, sobretudo em países já fragilizados por instabilidades econômicas e sociais. Nessa perspectiva, a resolução 1308 do CS da ONU é emblemática, pois é a primeira vez que o CS se pronuncia sobre os impactos provocados por um vírus, demonstrando preocupação com seus efeitos adversos sobre as operações de paz da ONU (ONU, 2000). Essa resolução cria um precedente decisivo no campo da securitização da saúde, visto que a principal instância da ONU responsável pela manutenção da paz e segurança internacionais, cujas resoluções são de natureza vinculantes (ONU, 1945), declara que

\footnotetext{
21 Traduzido do inglês: « the perceived increased threat of biological attack transformed public health from a non-factor in security discourse into a critical asset in achieving national, homeland, and international security against biological weapons »

22 Public Health Security and Bioterrorism Preparedness and Response Act, (EUA, 2002). Disponível em: http:// www.fda.gov/RegulatoryInformation/Legislation/ucm155733.htm. Acessado em 28 de fevereiro de 2016
} 
um tema de saúde é uma ameaça. Se essa resolução representa um caso bem sucedido de securitização do HIV/AIDS é uma questão ainda controversa; a iniciativa do CS é, contudo, um claro movimento securitizante (MICINNES; RUSHTON, 2012, p.117)

Esses desenvolvimentos evidenciam, portanto, que o nexo saúde-segurança não é um «estado natural das coisas» (natural state of affairs), mas sim uma construção política que depende de um interpretação particular sobre um fenômeno físico, eventos e condições; é um processo por meio do qual doença é definida como um problema, o que envolve interação, negociação e disputa entre atores (NUNES; 2015, p. 61). O crescente processo de securitização da saúde, um desenvolvimento específico no âmbito da relação saúde e segurança, resultou na emergência do conceito de « segurança sanitária » (health security), o qual passa a integrar o léxico das políticas de governos e de organizações internacionais, referindo-se às áreas em que interesses de segurança nacional e de saúde pública se sobrepõem (FIDLER, 2003, p. 789).

Identificar o escopo e o conteúdo do que se entende por segurança sanitária, depende de como segurança e saúde pública são definidas e articuladas e qual objeto referente está em foco. Nesse debate, quatro perspectivas são amplamente utilizadas para analisar a segurança sanitária no contexto global: segurança nacional, segurança humana, biossegurança e segurança sanitária mundial ou segurança global da saúde (global health security) (MCINNES, 2015, p. 7).

Temas de saúde tendem a figurar na agenda de segurança nacional se são concebidos como potencial ameaça à segurança interna do Estado, se impactam a estabilidade internacional ou causam níveis excepcionais de mortalidade (MCINNES; LEE, 2012, p. 157). Logo, numa perspectiva « estatista » de segurança sanitária, cujo foco é o Estado, as preocupações centrais são o bioterrorismo e as pressões desestabilizadoras de caráter econômico, político, social e migratório que a propagação de doenças possa engendrar. Destaca-se, contudo, que a relação causal entre a propagação de doenças, como o HIV/AIDS, e a instabilidade estatal e internacional é questionável, carecendo de evidências empíricas que sustentem essa causalidade (MCINNES, 2015).

O conceito de segurança humana, ao promover uma abordagem de segurança de caráter universal e centrada nos indivíduos, sustenta um entendimento mais amplo de segurança sanitária, embasando uma perspectiva « globalista » (DAVIES, 2010). Essa concepção abarca um rol muito mais amplo de ameaças, que inclui não apenas doenças infecciosas, mas também aspectos relacionados à pobreza, condições de vida, violência e conflitos (ONU, 2003, p.6). Como destaca Fidler, na abordagem de segurança humana «a saúde pública, portanto, escapa a sua tradicional associação com o Estado-nação e torna-se uma ideia ampla que reflete com maior precisão a 
natureza das ameaças à saúde na era global, especialmente as doenças infecciosas $»^{23}(2003$, p. 811 , tradução nossa).

A securitização da saúde manifesta-se também sob o já citado rótulo de biossegurança, termo de sentido amplo e vago, que cobre quase todas as ameaças decorrentes de armas biológicas até os riscos mais gerais de saúde. Biossegurança abarca, assim, tanto os riscos impostos pelo desenvolvimento de microorganismos em laboratórios que podem ser usados de modo inadvertido ou deliberado (MCINNES, 2015, p. 4) ${ }^{24}$, quanto a responsabilidade coletiva da sociedade de proteger a população contra perigos gerados por agentes patogênicos (FIDLER; GOSTIN, 2007, p. 4). Para Frédéric Gros a biossegurança representa uma nova era do que ele chama de « princípio segurança » (principe sécurité), que mobiliza mecanismos, dispositivos e técnicas de securitização do núcleo vital do indivíduo, a quem buscaria proteger, controlar e regular (GROS, 2012, p. 174).

O termo «segurança global da saúde» ou « segurança sanitária mundial » é amplamente associado à OMS e à noção de que os riscos à saúde pública têm sido globalizados. Apesar de essa expressão já fazer parte do vocabulário da organização desde 2001, com a resolução 54.14 da AMS Global Health Security: epidemic alert and response (OMS, 2001), uma formulação mais precisa do termo segurança sanitária mundial surge apenas em 2007 com o relatório Safer Future: a global public health security in the 21 st century, ano em que o RSI entra em vigor:

\begin{abstract}
Saúde pública global é definida como as atividades, tanto preventivas quanto reativas, necessárias para minimizar as vulnerabilidades em relação aos graves eventos de saúde pública que ameaçam a saúde coletiva das populações que vivem em diversas regiões e fronteiras internacionais (...) segurança sanitária mundial, ou a falta desta, pode afetar também a estabilidade econômica ou política, o comércio, o turismo e o acesso a bens e serviços e, se estes efeitos ocorrerem repetidamente, podem impactar a estabilidade demográfica. A segurança sanitária mundial abarca um amplo leque de temas complexos e desafiadores, desde o cenário internacional à residência individual, incluindo consequências para a saúde decorrentes da pobreza, guerras e conflitos, mudança climática, catástrofes naturais e desastres provocados pelo homem ${ }^{25}$ (OMS, 2007, p. 9, tradução nossa)
\end{abstract}

\footnotetext{
23 Traduzido do inglês: «public health thus, escapes its traditional association with nation-state and becomes a comprehensive idea that more accurately reflects the nature of health threats in the global era, especially infectious diseases »

${ }^{24}$ Nesse aspecto, McInnes ressalta o « dual use dilemma » que decorre do fato de que pesquisas e técnicas desenvolvidas em laboratórios podem ser usadas para benefício médico ou uso nocivo, prejudicial, o que demonstra, mais uma vez, a tensão e a complementaridade entre saúde e segurança e que o foco de segurança sanitária pode ser muito restrito (2015, p. 14).

25 Traduzido do inglês: « Global public health security is defined as the activities required, both proactive and reactive, to minimize vulnerability to acute public health events that endanger the collective health of populations living across geographical regions and international boundaries (...) global health security, or the lack of it, may also have an impact on economic or political stability, trade, tourism, access to goods and services and, if they occur repeatedly, on demographic stability. It embraces a wide range of complex and daunting issues, from the international stage to the individual household, including the health consequences of poverty, wars and conflicts, climate change, natural catastrophes and man-made disasters »
} 
Tendo como foco as coletividades e voltada à promoção da saúde face aos riscos globais, o paradigma da segurança sanitária mundial traz uma noção ampla de segurança sanitária, concebendo como ameaças não só os eventos que impactam diretamente a segurança nacional, mas também aqueles que afetam as condições de vida dos indivíduos. A segurança da saúde global, portanto, sobrepõe ameaças de naturezas diversas, incluindo, assim, num mesmo arcabouço, preocupações de segurança nacional e de segurança humana.

Apesar de as diversas abordagens demonstrarem que não há consenso sobre a definição de segurança sanitária (ALDIS, 2008), sobre como as áreas de saúde pública e segurança devem interagir e qual o objeto referente a ser adotado - o Estado, indivíduo ou coletividades -, não há dúvidas de que temas de saúde estão inseridos como high politics nas agendas de política externa e de segurança, como a declaração Ministerial de Oslo ressalta ${ }^{26}$. O que é comum a essas abordagens é o esforço de inserir problemas de saúde pública numa estrutura de segurança, o que revela a crença num relacionamento político de duas vias, ou seja, que a saúde pública pode ser reforçada por meio de um enfoque securitário, bem como segurança pode ser aumentada ao incorporar preocupações de saúde pública (FILDER, 2007, p.43).

Ao criar uma via de mão dupla, a securitização da saúde pública não apenas traz a segurança para o campo da saúde como atualiza o próprio sentido de segurança. É o que o relatório do Secretario Geral da ONU, A more secured world: Our shared responsibility (ONU, 2004), evidencia, ao congregar diferentes perspectivas de segurança, defendendo uma «comprehensive collective security ». Tendo em vista que, no mundo globalizado, a segurança dos diferentes atores é interdependente e as ameaças são inter-relacionadas, o relatório reconhece a pertinência das preocupações tradicionais de segurança nacional ao mesmo tempo que endossa a ampliação do conceito de segurança de modo a nele incluir questões de segurança humana. Assim, o painel associa e considera, numa mesma perspectiva de segurança, tanto atos de bioterrorismo como surtos naturais de doenças, defendendo a existência de mecanismos de cooperação entre o Conselho de Segurança e a OMS, com vista a estabelecer medidas efetivas de respostas a doenças infecciosas, sejam estas de causa natural ou intencional (ONU, 2004, parágrafo 144).

Segurança sanitária, portanto, enquadra-se em diferentes arcabouços teóricos correspondentes a narrativas e concepções de segurança diversas, as quais promovem determinada

\footnotetext{
${ }^{26}$ A Declaração Ministerial de Oslo foi uma iniciativa dos ministros de relações exteriores do Brasil, França, Indonésia, Noruega, Senegal, Africa do Sul e Tailândia, em março e 2007, com o objetivo de chamar a atenção para a crescente importância que temas de saúde publica têm ocupado na política externa dos Estados, apontando algumas medidas para tornar saúde publica um tema estratégico de política externa (AMORIN, C. et al, 2007).
} 
agenda e interesses (MCINNES, 20015, p.14). Essas narrativas mostram a complexidade social e teórica do nexo saúde-segurança, evidenciando que segurança sanitária é também um « conceito essencialmente contestado ». Por ser uma categoria política, ela está essencialmente aberta à contestação e mudança, o que justifica os diversos debates sobre seu significado e aplicação. Estudar as origens da segurança sanitária demanda, portanto, olhar não apenas para as tentativas explícitas de securitização de doenças através do ato de fala, mas também olhar para as correlações que são estabelecidas entre saúde e outros temas, sobretudo temas tradicionalmente do campo de segurança, bem como para conotações que são conferidas à saúde e doença (NUNES, 2015, p. 62).

A saúde pública já foi securitizada, ela está numa fase pós-securitização, em que compreender questões sanitárias através das lentes de segurança tornou-se um elemento permanente da governança global em saúde no século XXI, cabendo agora analisar as implicações desse processo no campo da saúde pública (FIDLER, 2007; p.41). O início da fase pós-securitização não significa que a securitização produziu uma relação clara e coerente entre segurança e saúde pública, ou que todo e qualquer tema de saúde foi securitizado, mas que «a crença política de que se pode melhorar a saúde pública, ao enquadrar e abordar seus problemas através de táticas e estratégias de segurança, tornou-se o principal vetor da governança em saúde pública» ${ }^{27}$ (Ibid., tradução nossa).

O período de negociação do RSI, de 1995 a 2005, ilustra essa passagem da fase de securitização para a era pós-securitizada. Enquanto a iniciativa de revisão do Regulamento foi motivada, em grande medida, por um ambiente marcado pela emergência de novas doenças infecciosas, o que fomentou incipientes discursos securitizadores em torno de questões sanitárias, a aprovação do RSI, dez anos mais tarde, representou a adoção de um instrumento de governança global $^{28}$ em saúde, negociado sob a perspectiva de segurança, que incorpora interesses que extrapolam os objetivos de saúde pública. Embora o léxico de segurança seja raramente explícito

\footnotetext{
27 Traduzido do inglês: « the policy belief that public health can be improved by framing and approaching problems through security-related tactics and strategies has become a leading driver of public health governance »

${ }^{28}$ No âmbito desta pesquisa, Governança Global significa: « The sum of the many ways individuals and institutions, public and private, manage their common affairs. It is a continuing process through which conflicting or diverse interests may be accommodated and cooperative action may be taken. It includes formal institutions and regimes empowered to enforce compliance, as well as informal arrangements, that people and institutions either have agreed to or perceive to be in their interest» (UNCGG 1995, p.2).
} 
em seu texto ${ }^{29}$, a negociação e a implementação do RSI será constantemente associada à estratégia de segurança sanitária mundial (OMS, 2007).

\subsection{OMS, Securitização e a revisão do RSI (2005)}

Uma mudança crucial na saúde pública nos últimos 20 anos envolveu o enquadramento de problemas específicos de saúde como ameaças à segurança e o desenvolvimento de uma estratégia para alcançar a segurança sanitária mundial. Essa estratégia vinculou a saúde global a interesses políticos centrais dos Estados, transformou as responsabilidades da OMS e produziu a revisão do Regulamento Sanitário Internacional ${ }^{30}$ (FIDLER, 2015, p.1888, tradução nossa)

A criação da OMS, em 1948, marca o nascimento da governança global em saúde pública ${ }^{31}$.

A Constituição da organização estabelece que saúde não é somente a ausência de doença, mas um estado de completo bem-estar físico, mental e social e que « a saúde de todos os povos é essencial para conseguir a paz e a segurança e depende da mais estreita cooperação dos indivíduos e dos Estados »(OMS, 1946, preâmbulo). Por muito tempo, essa relação entre saúde e segurança não influenciou a agenda da governança global da saúde, estando a OMS concentrada em seus programas de erradicação de doenças

O cenário pós Guerra Fria, contudo, pressiona a organização a tomar novos rumos. Conforme já mencionado, a emergência e re-emergência de doenças infecciosas, como a

${ }^{29}$ O RSI faz menciona a palavra « segurança » em cinco momentos (OMS, 2005):

- No preâmbulo quando faz referência às resoluções 54.14 sobre segurança mundial em saúde: alerta e resposta em epidemias;

- Na definição de « medidas de saúde » : « significa os procedimentos aplicados para evitar a propagação de contaminação ou doença; uma medida de saúde não inclui medidas policiais ou de segurança »

- Parágrafo 5 do artigo 23: « qualquer exame, procedimento médico, vacinação, ou aplicação de outra medida profilática que envolva um risco de transmissão de doença só será realizado ou administrado ao viajante com conformidade com as diretrizes e normas de segurança nacionais e internacionais estabelecidas, de maneira a minimizar esse risco »"

- Parágrafo $\S$ do artigo 28: « (...) o capitão da embarcação ou comandante da aeronave podem tomar as medidas de emergência que forem necessárias para assegurar a saúde e segurança dos viajantes a bordo. Ele ou ela informará a autoridade competente, assim que possível, quanto às medidas tomadas consoante a este Parágrafo"

- Anexo 7: « Os Estados Partes designarão centros específicos de vacinação com a febre amarela em seus territórios, a fim de garantir a qualidade e segurança dos procedimentos e dos materiais utilizados »

30 Traduzido do inglês: «A seminal change in global health during the past 20 years involved the framing of specific health problems as security threats and development of a strategy to achieve global health security. This strategy connected global health with core political interests of states, transformed the responsibilities of WHO, and produced the revised International Health Regulations"

31 Para definição de Governança Global, nota 28. 
tuberculose e meningite, passa a inquietar os Estados ocidentais, que buscam novas medidas de controle e vigilância de doenças. Essa preocupação é patente sobretudo nos Estados Unidos, onde se publica, em 1992, o relatório do Instituto de Medicina (IOM), Emerging Infectious: Microbial Threats to Health in the United States, trazendo o conceito de « doenças infecciosas emergentes » (emerging infectious diseases - EID) (IOM, 1992). Esse conceito difere das definições prévias de doenças infecciosas ao pressupor um mundo microbiótico em constante mudança, com grande potencial para novas doenças, o que leva à interpretação desse risco como ameaça à segurança nacional dos EUA (WEIR; MYKHALOVSKIY, 2010, p. 171).

A noção de « doenças infecciosas emergentes », ao incorporar não apenas doenças existentes, mas também as de origem desconhecida e potencialmente infecciosas, capturou a atenção das autoridades de saúde pública que buscaram, a partir de então, reformular os sistemas de identificação e de controle internacional de doenças transmissíveis. A concepção de EID, portanto, representou um rompimento epistemológico no controle de doenças transmissíveis, operando como o alvo discursivo para uma nova forma de pensar e agir em relação a surtos de doenças contagiosas (Ibid., p.13).

Weir e Mykhalovskiy (2010) destacam a importância do conceito de EID, que ao reenquadrar a prevenção e o controle de doenças infecciosas como um problema não somente de saúde pública, mas também de segurança nacional, fomentou o processo de securitização da saúde nos EUA. O relatório do IOM aponta a necessidade de uma ação coordenada no âmbito internacional para enfrentar essa ameaça, sugerindo que os EUA deveriam assumir a liderança, levando essa questão até à Assembleia Mundial da Saúde. O relatório recomendou que o país se dirigisse à OMS para propor a implementação de um sistema de vigilância global com capacidade de detectar e responder a surtos de doenças, pois o envolvimento ativo da OMS seria pré-requisito para uma ação bem sucedida (DAVIES; KAMRADT-SCOTT; RUSHTON, 2015, p.20).

O relatório do IOM teve grande repercussão nos países ocidentais, que passaram a pressionar a OMS, sob liderança da aliança dos EUA e Canadá, em favor de uma reformulação do seu sistema de controle de doenças infecciosas, com objetivo de conter as doenças emergentes. Em resposta a essa demanda, duas reuniões foram realizadas em Genebra, em abril de 1994 e janeiro de 1995, para discutir os temas levantados pelo relatório (WEIR, 2015, p.19). Essas reuniões serviram de inspiração para o Secretariado da OMS argumentar pela revisão do RSI, uma vez que o ambiente internacional e a audiência tornavam-se favoráveis ao re-exame dos meios de controle de doenças infecciosas. 
Nesse momento, a efetividade do RSI em vigor já era questionada, especialmente pelo baixo índice do comprometimento dos Estados com sua implementação e pelo restrito escopo de aplicação, tendo em vista que o RSI de 1969 se aplicava somente a três doenças: febre amarela, cólera e peste negra ${ }^{32}$. É nesse contexto de crescente preocupação com doenças infecciosas emergentes que se insere o início do processo de revisão do RSI, em maio de 1995, com a resolução da AMS 48.7. Nesse momento, enquadrar o processo de revisão como um imperativo que nenhum Estado poderia objetar estava intrinsecamente vinculado ao discurso emergente em torno das implicações de segurança nacional resultantes dos surtos de doenças infecciosas transfronteiriças (DAVIES; KAMRADT-SCOTT; RUSHTON, 2015, p. 23).

Destaca-se que iniciativa de reforma do RSI ocorre juntamente com a aprovação da resolução 48.13 Communicable Disease Prevention and Control: New, Emerging, and Re-emerging Infectious Disease (OMS 1995), que internacionaliza o conceito de EID e o programa do IOM, ao traduzir a concepção de EID no discurso normativo de saúde pública internacional endossado pela OMS (WEIR, 2015, p. 20). Assim, novas estruturas são criadas no âmbito da OMS para dar uma resposta mais efetiva à prevenção e controle de doenças, como a criação da divisão de Emerging and Other Communicable Disease, em outubro de 1995, e do Global Outbreak Alert and Response Network (GOARN), institucionalizado em 2000, com o objetivo de « elevar a segurança sanitária mundial estabelecendo parcerias com uma rede operacional global de alerta e resposta » (OMS, 2000, p. 3-4) ${ }^{33}$. Essas iniciativas representam uma nova concepção do controle de doenças, designado por Weir e Mykhalovskiy (2010) de « mundo em alerta » (world on alert), que seria a primeira formulação estratégica para a « vigilância global de emergência » que adquirirá forma legal com a adoção do novo RSI.

O novo Regulamento não deve ser entendido somente como resposta ao surgimento de surtos de doenças que escapavam ao escopo do antigo RSI, mas também como resultado de um processo discursivo, embasado, sobretudo, no novo paradigma de «segurança sanitária mundial » (DAVIES; KAMRADT-SCOTT; RUSHTON, 2015, p. 7), inaugurado com a resolução da AMS 54.14,

\footnotetext{
${ }^{32}$ A OMS listou cinco importantes limites do antigo regulamento: possuía uma cobertura restrita; dependia inteiramente da notificação do país afetado para que a organização pudesse agir; o regulamento não especificava como a OMS e o país afetado iriam colaborar e cooperar na contenção de doenças; não previa incentivos para encorajar o cumprimento das normas do regulamento e medidas de prevenção à propagação de doenças (OMS, 2002, p. 3).

${ }^{33} \mathrm{O}$ GOARN constitui uma rede composta de instituições nacionais e não-governamentais de vigilância, que foi estabelecida com capacidade de resposta a três tipos de doenças: EID, surtos recorrentes de doenças e liberações acidentais ou deliberadas de agentes biológicos em populações humanas ou animais. Percebe-se, assim que o GOARN tem uma dimensão de segurança internacional integrada às suas operações (OMS, 200a, p. 3-4)
} 
Global health security - epidemic alert and response (OMS, 2001) ${ }^{34}$. Nessa resolução, a OMS reconhece o impacto da globalização no recente aumento de casos de doenças infecciosas, relacionando os conceitos de segurança e saúde a uma estratégia global para prevenir a propagação internacional de doenças transmissíveis. A resolução 54.14 é considerada o primeiro passo para identificar o processo de revisão do RSI como parte essencial dessa estratégia de segurança global.

A OMS começa, assim, a enquadrar seus esforços em relação às doenças infecciosas em termos de segurança sanitária mundial, apropriando-se conscientemente do conceito de segurança para promover o controle global de doenças infecciosas (FIDLER, 2003, p. 793), demonstrando clara habilidade em moldar a agenda e exercer a liderança nas discussões sobre as normas do novo regime de segurança sanitária que emergia (DAVIES; KAMRADT-SCOTT; RUSHTON, 2015 p. 41).

Dessa forma, apesar de a autoridade para revisar o RSI recair em última instância sobre os Estados membros, o Secretariado da OMS desempenhou um papel de extrema relevância nas negociações. Atuando em um cenário global marcado pelo alto nível de securitização das doenças infecciosas, o Secretariado faz do enquadramento de temas de saúde como segurança um discurso chave na revisão do RSI, construindo a centralidade da OMS no regime de controle de doenças infecciosas.

Os eventos de 2001 estimulam diversas respostas institucionais em nível global, sendo a primeira resposta da OMS aos ataques de antraz a divulgação de uma pré-versão do Public health response to biological and chemical weapons: WHO guidance, em outubro de 2001 (OMS, 2001a). Em dezembro, o Secretariado apresenta ao Conselho Executivo o relatório EB 109/26 referente à utilização deliberada de agentes químicos e biológicos com a intenção de causar danos e a resposta de saúde pública (OMS, 2001b), no qual afirma que as medidas a serem tomadas em relação ao uso deliberado de agentes químicos e biológicos recaem também sobre o setor de saúde e que a melhor forma de preparar o sistema de saúde pública para um possível evento dessa natureza é exercer continuamente uma crescente vigilância sanitária, reforçar os planos de urgência e tornar cada vez mais eficaz a capacidade de resposta nacional. Em caso de uso deliberado de agentes biológicos, químicos ou radiológicos, independentemente de ser caracterizado como um ato de terrorismo ou uma emergência de saúde de causa natural, a OMS se concentrará, essencialmente, nas eventuais consequências para a saúde pública, (Ibid, p.1).

\footnotetext{
${ }^{34}$ Ao adotar essa resolução, à exceção da China, todos os Estados-membros expressaram seu apoio à OMS na identificação de surtos de doenças infecciosas como uma ameaça à segurança e no desenvolvimento de uma rede internacional que poderia ser operacionalizada em qualquer lugar para prestar assistência aos países na contenção de surtos de doenças (DAVIES; KAMRADT-SCOTT; RUSHTON, 2015, p.35).
} 
Esse documento levou o Conselho Executivo a adotar a resolução EB 109.R5 de 17 de janeiro de 2002 (OMS, 2002a), convidando os Estados a considerar qualquer uso deliberado de agentes químicos ou biológicos, ou ataques radio-nucleares, como uma ameaça global à saúde pública e a responder a tais ameaças em outros países compartilhando expertises, recursos e suprimentos, a fim de rapidamente conter ou mitigar os seus efeitos. Roga, ainda, ao Diretor Geral que continue a revisão do RSI e que analise a possibilidade de se elaborar outros instrumentos e mecanismos coletivos de ação em saúde pública com vista a prevenir o uso deliberado de agentes químicos, biológicos e radio-nucleares.

Em abril de 2002, o Secretariado da OMS produziu o relatório A55/20 Deliberate Use of Biological and Chemical Agents to Cause Harms (OMS 2002c), apontando que, para responder ao uso deliberado de tais agentes, a organização deveria fortalecer sistemas de alerta e resposta em saúde pública em todos os níveis. Caso a ONU estivesse implicada na investigação de surtos de doenças, o relatório estabelece que a OMS poderia ser solicitada a fornecer apoio técnico ou tornar disponível seus recursos e mecanismos. Temas não usuais de saúde pública, mas que estão relacionados à investigação e notificação de um possível uso de armas químicas ou bacteriológica, permaneceriam sob a responsabilidade da ONU.

A seguir, o mandato internacional de segurança sanitária global foi expandido com a Resolução da AMS 55.16, em maio de 2002, intitulada Global Public Health Response to natural occurrence, accidental release or deliberate use of biological and chemical agents or radionuclear material that affect health (OMS, 2000b), que teve como base o relatório do Secretariado de abril. Essa resolução reconhece que um dos métodos mais eficazes para se preparar contra uma doença causada deliberadamente é fortalecer a vigilância em saúde pública e as atividades de resposta voltadas às doenças de origem natural e acidental. Nesse sentido, a OMS pede aos Estados que adotem planos nacionais de vigilância em saúde e que considerem qualquer uso deliberado de agentes químicos, biológicos ou radio-nucleares com intuito de causar danos como uma ameaça à saúde global, exortando à colaboração entre os Estados e o compartilhamento de recursos e expertise em caso de uma epidemia causada deliberadamente (Ibid.).

Dessa forma, a crescente obsessão securitária após 2001 promove a biodefesa como prioridade na agenda internacional e ressignifica o papel das infraestruturas de saúde pública, notadamente os sistemas de vigilância e controle de doenças infecciosas, inserindo-os em estratégias de defesa e segurança. Esse contexto influencia os trabalho da OMS, a qual passa a reproduzir essa tendência securitizadora: «medidas de biodefesa, com a concomitante securitização da saúde públi- 
ca têm ocupado o centro do debate no esforço de conter as novas ameaças existenciais identificadas de bioterrorismo $»^{35}$ (KELLE, 2007, p. 219). Isso se reflete na ampliação do escopo do « mundo em alerta » em direção a uma « vigilância global de emergência » e na constante presença da terminologia de segurança sanitária nas resoluções e relatórios da OMS, bem como no processo de revisão do RSI.

O relatório da OMS de 2003, Global Defense Against Infectious Disease Threat, é produto desse novo olhar sobre a saúde pública, já que insere explicitamente questões sanitárias no arcabouço de segurança e afirma que doenças infecciosas são uma ameaça externa que colocam em risco a segurança nacional, ao provocar instabilidade e mobilizações sociais (OMS, 2003; p. 15). Nessa perspectiva, a OMS afirma que « doenças infecciosas emergentes e com potencial epidêmico são um desafio de segurança específico tendo em vista que elas se comportam de forma que podem sobrecarregar infraestruturas sociais, causar perturbações demográficas, desestabilizar regiões e, assim, ameaçar a segurança sanitária mundial ${ }^{36}$ (Ibid., tradução nossa).

Preparar-se para um possível ataque terrorista passou a ser, à época, o tema de mais alta relevância relacionado a doenças infecciosas (OMS, 2003; p.16). A OMS qualificou, assim, o possível uso deliberado de agentes biológicos com a intenção de causar danos como uma nova forma de ameaça imprevisível de epidemia, classificando esse tipo de evento no grupo de doenças emergentes de potencial epidêmico. A organização destaca que o sistema de saúde pública será o primeiro a detectar casos de doenças, de origem deliberada ou não, constituindo, portanto, a linha de frente nas estratégias de preparo e de resposta a eventos de uso intencional de agentes infecciosos e tóxicos. Nesse sentido, alerta-se para o « uso dual » dos sistemas de saúde pública: enfrentar doenças infecciosas e prover segurança, uma vez que se preparar para um possível surto de doenças é também preparar-se para o uso deliberado de agentes patogênicos (Ibid, p. 17).

« As preocupações exacerbadas com a associação entre saúde pública e segurança no RSI de 2005 decorrem da percepção de que uma vigilância apropriada em saúde pública e respostas intervencionistas são necessárias aos eventos de doenças, independentemente de sua origem ou fonte» ${ }^{37}$

\footnotetext{
35 Traduzido do inglês: biodefense measures, with the concomitant securitization of public health have been placed center stage in the effort to counter the newly identified existential threat of bioterrorism »

36 Traduzido do inglês: " emerging and epidemic-prone infectious disease are a particular security challenge as they behave in ways that can overwhelm social infrastructures, cause demographic upheaval, destabilize regions and thus threaten global health security »

37 Traduzido do inglês: « Overriding concerns about mixing public health and security in the IHR 2005 was the realization that appropriate public health surveillance and intervention responses are needed to disease events whatever their source and origin »
} 
(FILDER; GOSTIN, 2008, p.138, tradução nossa). Com base em entrevistas realizadas em Genebra, em dezembro de 2005, com negociadores que participaram das reuniões finais de revisão do RSI, em maio de 2005, Kelle (2007, p. 226) sustenta que o discurso sobre a negociação do RSI ganha uma nuança diferente ao incluir essa preocupação com doenças cuja origem é o uso deliberado de agentes patogênicos, químicos ou radio-nucleares. Essa temática gera controvérsias ao longo da revisão, levando ao impasse das negociações em certos momentos.

Apesar de a expressão segurança sanitária mundial ganhar uma formulação mais concreta nos documentos da OMS apenas em 2007, como já ressaltado, ${ }^{38}$ o discurso de segurança sanitária esteve presente durante o processo de revisão do RSI e foi fundamental para mobilizar os atores ao longo das negociações, gerando vontade política nos Estados para que se alcançasse um acordo final. Conforme Davies, Kamradt-Scott e Rushton destacam: «a ideia de segurança sanitária mundial foi uma ferramenta discursiva crucial utilizada pela OMS e por outros, no início do século XXI, para promover, de forma bem sucedida, a necessidade de revisão do RSI e, posteriormente, promover a necessidade dos Estado em se comprometerem com as novas regras $»^{39}(2015$, p. 13, tradução nossa).

Os discursos articulados em torno do paradigma de segurança sanitária mundial e o contexto marcado pela crescente securitização da saúde pública influenciaram o curso das negociações do RSI, bem como o conteúdo do documento final. O RSI introduz novos conceitos e procedimentos que refletem tanto a construção política de doenças infecciosas como ameaças em potencial à segurança quanto o « uso dual » dos sistemas de saúde pública, sustentando, assim, uma nova estrutura de vigilância e resposta global ao mundo microbiótico. O novo Regulamento é, portanto, o instrumento jurídico que fundamenta a segurança sanitária mundial como estratégia da governança global em saúde.

\footnotetext{
${ }^{38}$ Ver p. 25

${ }^{39}$ Traduzido do inglês: « The idea of global health security was a crucial discursive tool used by the WHO and others in the early twenty-first century to successfully promote the need to revise the IHR and subsequently to promote the need for states to comply with the new rules »
} 


\section{O REGULAMENTO SANITÁRIO INTERNACIONAL (2005)}

O atual RSI inovou o campo da regulação e governança em saúde pública, introduzindo mudanças substanciais no regime internacional de controle de doenças infecciosas. Revisar o RSI envolveu um longo e árduo processo de negociação, em que interesses não comuns à área de saúde pública, notadamente de segurança internacional, desempenharam papel fundamental para a adoção de determinados dispositivos. Para compreender esse processo e a relevância que o novo Regulamento assume no campo da saúde global, esta segunda parte está dividida em quatro seções. As duas primeiras são dedicadas às etapas do processo de revisão e aos fatores que levaram ao destravamento das negociações a partir do final de 2002; na terceira seção serão abordados os temais mais polêmicos e de difícil consenso envolvendo os interesses de segurança e, por fim, serão analisadas as principais mudanças introduzidas pelo novo Regulamento, sob a perspectiva de segurança sanitária.

\subsection{0 processo de negociação (1995 - 2005)}

As negociações do RSI em vigor tiveram início em maio 1995, com a já citada resolução 48.7 da Assembleia Mundial da Saúde, e se desenvolveram em várias etapas até a adoção do Regulamento final em 2005. Primeiramente, em dezembro de 1995, a OMS realizou consultas informais com um grupo de especialistas em saúde pública para considerar a revisão do RSI à luz das experiências vivenciadas durante os surtos de cólera no Peru em 1991, de peste na Índia, em 1994, e Ebola no Zaire (Congo) em 1995 (SEARO, 1998). O grupo recomendou uma ampla base de notificações, de forma que todos os surtos de doenças de urgente importância internacional fossem reportados a OMS, propondo a notificação imediata com base em síndromes clínicas, ficando pendente a determinação do agente causador (Ibid.).

Desde o início das negociações, todos os Estados membros da OMS foram convidados a designar pontos focais nacionais de contato com a organização para facilitar a troca de informações durante o processo de revisão. Os países eram regularmente informados sobre o andamento da revi- 
são por meio do relatório semestral publicado no Weekly Epidemiological Record (WER) ${ }^{40}$. O próximo passo foi a criação de um grupo informal de trabalho, composto por analistas legais e especialistas em saúde pública, para dar seguimento às propostas sugeridas nas consultas informais. Esse grupo se reuniu duas vezes em 1996 e uma vez em 1997, completando seu trabalho em junho deste ano (Ibid., p. 2).

O grupo de especialistas reconheceu que a aplicação do RSI era muito influenciada pelas mudanças na situação da saúde global e pelo aumento das viagens internacionais, concluindo que, apesar de os princípios fundamentais do RSI permanecerem válidos, há uma grande necessidade de coordenação global em monitoramento, respostas e notificação. Concluiu também que o controle de doenças infecciosas, no plano internacional, é mais efetivo por meio do aumento da vigilância e estratégias de intervenção do que da aplicação de medidas nas fronteiras, que incidem em pontos distantes das fontes de infecção.

Com base nas propostas e discussões desse grupo, o Comitê Internacional de Vigilância de Doenças Comunicáveis (Committee on International Surveillance of Communicable Disease, CISCD) da OMS elaborou uma proposta de revisão do RSI, que foi divulgada aos Estados em janeiro de 1998. Nessa primeira versão provisória ${ }^{41}$, o princípio fundamental do RSI de 1969 - máxima proteção contra a propagação de doenças com mínimas interferências no comércio e viagens - é mantido, e a estrutura do novo Regulamento seria composta por um documento estrutural contendo os princípios gerais, as medidas apropriadas de saúde pública e provisões legais em relação à utilização do RSI; anexos descrevendo medidas técnicas e requerimentos específicos; e guidelines de operação para acompanhar o RSI revisado e assistir os Estados em sua aplicação (OMS, 1998). A intenção era garantir a longevidade do RSI, juntamente com a flexibilidade das provisões técnicas.

Propõe-se a notificação com base em síndromes clínicas, como sugerido nas consultas informais de 1995, devendo um surto de doença ser notificado assim que fossem atendidas duas condições: corresponder a um caso das síndromes definidas no regulamento ${ }^{42}$ e representar um evento de importância internacional. As demais síndromes deveriam ser analisadas com base nos seguintes

\footnotetext{
${ }^{40}$ Todos as edições do WER estão disponíveis no site da OMS: $\underline{\text { http://www.who.int/wer/en/ }}$

${ }^{41}$ Essa primeira versão do RSI não está disponível na base de dados online da OMS. Tivemos contanto com essa versão em papel, a qual foi fornecida por um dos funcionários do escritório da OMS em Lyon, em julho de 2015.

42 As síndromes identificadas que potencialmente poderiam causar um surto de saúde pública de urgente importância internacional eram: síndrome aguda de febre hemorrágica, síndrome respiratória aguda, síndrome neurológica aguda e síndrome de icterícia. Doenças endêmicas ocorridas regularmente não seriam notificadas, a menos que um surto ocorresse tendo uma característica particular que indicasse uma questão de saúde pública de urgente importância internacional - "urgent international public health importance" (OMS, 1998).
} 
critérios: rápida transmissão na comunidade, taxa de mortalidade inesperadamente alta, nova síndrome reconhecida, alto perfil político e mediático e restrição ao comércio e viagens. O objetivo era alertar para um problema de doença o mais rápido possível e promover uma rápida investigação para conter a fonte de infecção (OMS, 1998).

Para avaliar o funcionamento desse novo mecanismo, a OMS organizou um estudo piloto em 21 países, incluindo países com extensas relações internacionais e diferentes sistemas de vigilância sanitária. África do Sul, Brasil, Nigéria, México, Peru, França, Rússia, Índia, Tailândia, Japão e Singapura foram alguns dos países selecionados. Esse estudo piloto buscava avaliar os critérios propostos de notificação, a definição de casos baseados em síndromes e testar, no plano nacional, os mecanismos para a notificação nas existentes infraestruturas de vigilância nos países, bem como a capacidade da OMS para gerenciar e responder a informação recebida (SEARO, 1998, p.3-4).

Após a versão de janeiro de 1998, o CISDC será o comitê de especialistas encarregado de preparar o texto final do RSI revisado, com base nos comentários e considerações resultantes do estudo piloto. Os membros do comitê foram selecionados e nomeados pelo Diretor Geral de modo a incluir especialistas de diferentes áreas da saúde pública e representantes de todas as regiões dos países da OMS. O CISCD reuniu-se em novembro de 1998 para considerar o processo de revisão, executar uma avaliação interina do estudo piloto, discutir aspectos legais do RSI e rever a versão provisória (Ibid.).

O prazo final para que uma versão final do RSI fosse submetida à Assembleia Mundial da Saúde era maio de 2000. Porém, como o estudo piloto demonstrou que a notificação com base em síndromes clínicas, embora útil em nível nacional, não seria a forma mais apropriada para uma ampla estrutura de regulamentação, principalmente pelas dificuldades de se reportar uma síndrome, foi necessário prorrogar o prazo para concluir a revisão (OMS, 1999, p.2). O relatório de janeiro de 2000 já sinaliza a inadequação do sistema de notificações com base em síndromes, apontando que a direção a ser tomada pelo RSI seria a de que todos os eventos de saúde pública de importância internacional fossem notificados (OMS, 2000, p. 36). Em 2001, com a fusão das equipes de revisão do RSI e a equipe responsável pelo desenvolvimento do sistema de alerta e resposta a surtos de doenças da OMS, o Secretariado abandonou a tentativa de simplesmente atualizar o antigo RSI de 1969 e escolheu revisar substancialmente todo o regime baseado em novos conceitos e métodos (DAVIES; KAMRADT-SCOTT; RUSHTON; 2015, p.35).

Os principais desafios encontrados até então na revisão do RSI eram: garantir que somente riscos de saúde pública de urgente importância internacional fossem notificados sob a égide do 
novo regulamento; evitar a estigmatização e desnecessários impactos negativos sobre viagens e comércio internacionais, decorrentes de notificações improcedentes oriundas de fontes não estatais; garantir que o sistema de notificação fosse sensível o suficiente para identificar novos ou re-emergentes riscos de saúde pública (OMS, 2001c).

Na resolução 54.14 Global Health Security: epidemic alert and response, de maio de 2001, fica expresso o apoio da AMS ao processo de revisão do RSI, incluindo o desenvolvimento de um critério, a decision tree, para notificação dos eventos que pudessem constituir uma « emergência de saúde de importância internacional» (OMS, 2001). A Assembleia pede aos Estados que participem ativamente, junto com o Secretariado e outros parceiros técnicos, na verificação e validação de informações de vigilância concernentes a emergências de saúde de importância internacional, além de desenvolver e atualizar os planos nacionais. A previsão para as próximas etapas do processo de revisão consistiriam em preparar um projeto de texto revisado do RSI até o final de 2002, organizar grupos de trabalhos regionais para avaliar a possibilidade de aplicação do novo texto do RSI até o final de 2003 e submeter o texto revisado a AMS, no mais tardar, até maio de 2004 (OMS, 2001c).

Desde 2001, a OMS passa a trabalhar com o Departamento de Epidemiologia do Instituto Sueco de Controle de Doenças Infecciosas (Swedish Institute of Infectious Disease, SMI) para definir a tipologia dos eventos relacionados à saúde que seriam notificados no âmbito do novo regulamento (OMS, 2003a). Essa parceria resultou, em 2002, em alguns critérios que poderiam ser empregados para identificar uma emergência de saúde pública internacional e no desenvolvimento de uma ferramenta para guiar os Estados na identificação de quando um evento deveria ser notificado.

No WER de maio de 2002 são apresentados aspectos de extrema relevância do novo regulamento: o desenvolvimento de uma ferramenta para auxiliar os Estados na identificação de uma emergência de saúde pública baseada na resposta a quatro perguntas - que constará no Anexo 2 do documento final ${ }^{43}$ - e a proposta de que o RSI determine as capacidades básicas que os sistemas nacionais de saúde deverão desenvolver para detectar, avaliar e responder a emergências de saúde pública. Ademais, aponta-se que, sob o novo regulamento, a OMS poderá levar em consideração as informações de saúde pública provenientes de fontes não-estatais e poderá emitir recomendações temporárias aos Estados Partes (OMS, 2002d, p. 158). Logo, dispositivos fundamentais do novo

\footnotetext{
${ }^{43} \mathrm{O}$ algoritmo de decisão que auxiliará os Estados a decidirem sobre a notificação ou não de um evento de doença, que consta no Anexo II do RSI de 2005 é baseado em quatro perguntas fundamentais: « o impacto do evento sobre a saúde pública é grave? »; « o evento é incomum ou inesperado? »; « há risco significativo de propagação internacional? »; há um risco significativo de restrições ao comércio ou viagens internacionais? » (ANVISA, 2009, p. 62). O WER de maio de 2002 já sinaliza as possíveis perguntas que farão parte desse instrumento de decisão (OMS 2002d, p. 158)
} 
RSI, que estava sendo negociado desde 1995, são mencionados, explicitamente, somente após 7 anos de negociação.

Ainda no WER de maio, destaca-se que a estratégia da OMS para segurança sanitária mundial, em consonância com a resolução 54.14 já mencionada, será pautada em três pilares principais: programas específicos para a prevenção e controle de ameaças de epidemias já conhecidas, como a influenza e o cólera; detecção e resposta a emergências sanitárias resultantes de circunstâncias inesperadas ou de etiologia desconhecia; e o fortalecimento das infraestruturas nacionais de vigilância e resposta em saúde (Ibid.). O RSI revisado proverá, assim, a estrutura necessária dentro do mandato da OMS em saúde pública global para executar essas atividades, sendo vinculado a atividades em nível global e nacional (Ibid).

No relatório Global crises, global solutions: Managing public health emergencies of international concern through the revised International Health Regulations (OMS, 2002), o Secretariado discute as possíveis mudanças no RSI, apresentando 10 propostas de alteração, que embasaram vários artigos do novo Regulamento. Dentre estas, destacam-se a notificação de emergências de saúde pública de importância internacional, o estabelecimento de pontos focais, a utilização de informações de fonte não estatal e a necessidade dos Estados desenvolverem capacidades para detectar e notificar riscos de doenças. Nesse relatório, percebe-se que o novo RSI terá não só um escopo de aplicação muito mais amplo, mas sim uma mudança significativa em relação ao comportamento esperado dos Estados.

As propostas de alteração do RSI foram justificadas pela natureza das ameaças à segurança sanitária global impostas pelas doenças infecciosas e a inabilidade dos atuais sistemas de saúde para responder adequadamente a tais ameaças. A OMS sugere que, ao invés de enfatizar medidas de controles de fronteiras para prevenir o ingresso de doenças, deve-se concentrar na contenção destas em sua fonte de origem; sugere ainda que os governos devem se esforçar ao máximo para facilitar essa contenção, afirmando que a segurança contra essas ameaças à saúde somente poderiam ser alcançadas através de uma rede cooperativa de conhecimento e resposta (OMS, 2002).

A partir de 2003, o processo de revisão entra em uma nova etapa com a criação do grupo intergovernamental de trabalho (GIT) pela AMS, por meio da resolução 56.28 (OMS, 2003a), na qual consta também um novo prazo para a adoção do texto final do Regulamento: maio de 2005. Essa etapa da revisão será marcada pela aceleração das negociações, com a promoção de consultas regionais e o envio de propostas dos Estados sobre os dispositivos do novo Regulamento. 
Uma nova versão do RSI foi divulgada pelo Secretariado em 12 de janeiro de 2004 (OMS, 2004), contendo 55 artigos, que constituem a essência do Regulamento, mais 10 anexos que se referem a questões técnicas específicas e a procedimentos para o processo de decisão durante uma emergência de saúde pública internacional. Essa primeira versão completa, texto base do novo RSI, foi submetida a consultas regionais entre março e junho de 2004, nas seis regiões que compreendem todos Estados membros da organização. Uma nova versão do RSI foi formulada entre julho e agosto de 2004 pelo Secretariado, com base nas consultas regionais e propostas feitas pelos Estados (OMS, 2004a). Essa versão foi divulgada em 30 de setembro e serviu de base para a primeira sessão de negociação do grupo intergovernamental de trabalho (OMS, 2004b).

Em janeiro de 2004, o Conselho Executivo decidiu que o grupo intergovernamental de trabalho teria sua primeira sessão de negociação em novembro (OMS, 2004a). Nessa primeira reunião, realizada de 1 a 12 de novembro, Mary Whelan, Embaixadora da Irlanda, foi nomeada Presidente do grupo de trabalho, e foram escolhidos vice-presidentes representando cada uma das seis regiões da OMS. Para cobrir todos os tópicos a serem discutidos nas reuniões intergovernamentais, foram criados três subgrupos de trabalho, tendo cada um 2 co-presidentes. Whelan destaca que algumas das negociações mais amplas eram conduzidas por especialistas de diferentes áreas do governo e não por diplomatas, e que as missões diplomáticas dos países, baseadas em Genebra, desempenharam um importante papel de apoio às delegações (WHELAN, 2008, p.6).

Com base na primeira reunião do GIT, a Presidente propôs uma nova versão do RSI, em 24 de janeiro de 2005 (OMS, 2005a), assinalando os pontos que demandavam maiores discussões. As negociações de novembro ocorreram no Palais des Nations, em Genebra, mas, em fevereiro, quando houve o segundo ciclo de negociação do grupo de trabalho, elas foram deslocadas para a sede da OMS, o que significou passar para salas de reuniões menores, criando condições mais reservadas para conduzir as negociações e maior interação entre as delegações (WHELAN, 2008). Não foi possível, contudo, chegar a um consenso sobre o documento final em fevereiro, logo, as negociações finais foram adiadas para maio de 2005.

Antes da negociação final, ocorreram reuniões regionais e sub-regionais, com base na versão proposta pela Presidente do grupo de trabalho, o que contribuiu para que, de fato, a revisão avançasse. As negociações finais ocorreram em 12 e 13 de maio de 2005, um pouco antes da AMS. Chega-se a um acordo nas primeiras horas do dia 14 e, no dia 23 de maio, e a AMS adota o novo RSI por unanimidade com resolução 58.3 (WHELAN, 2008, p.15) . O novo RSI entrou em vigor, como previsto em seu próprio texto, em 15 de junho de 2007. 
Abaixo apresentamos um quadro comparativo com a cronologia das principais etapas da negociação do RSI e eventos internacionais relevantes a esse processo, bem como as resoluções e relatórios da OMS que trazem a perspectiva de saúde e segurança. 
Cronologia das negociações do RSI

Maio

1995

Dez

1995

1996-9

7

Janeiro

1998

1998-

1999
Inicio das negociações do RSI (resolução AMS 48.7)

Consultas informais com especialistas em saúde pública

Grupo de trabalho informal para discutir conceitos para o novo RSI

Primeira versão provisória do RSI

Estudo piloto para avaliar a notificação de síndromes em 21 paises

\section{Eventos internacionais/Resoluções da}

\section{OMS}

Década

1980/90

1991

Março

1995

Doenças infecciosas emergentes e reemergentes

Descoberta de armas químicas nos antigos países da União Soviética e no Iraque

Ataque de Gas Sarin em Tóquio

Maio

1995

Resolução 48.13 Communicable Disease

Prevention and Control: New, Emerging, and Re-emerging Infectious Disease
2000

Maio

2001

Set.

2001

Set -

Nov

2001

Out.

2001

Dez.

2001

Jan 2002

Abril

2002

Maio

2002
O GOARN é institucionalizado

Resolução 54.14 Global health security epidemic alert and response

Ataques de terroristas em Nova lorque

Ataques de antraz nos Estados Unidos

OMS divulga seu guia Public health response to biological and chemical weapons

Relatório do Secretariado EB 109/26 - The deliberate use of biological and chemical agentes to cause harm: public health response

Resolução EB 109.R5 - Global public health response to the deliberate use of biological and chemical agents, and radio-nuclear attacks to cause harm

Relatório A55/20 - Deliberate Use of Biological and Chemical Agents to Cause Harms

Resolução 55.16 Global public health response to natural occurrence, accidental release or deliberate use of biological and chemical agents or radionuclear material that affect health 
Relatório Global crisis - global solutions:

2002

Managing public health emergencies of international concern through the revised International Health Regulations

Nov.

Eclosão da epidemia de SARS na China

2002

Março Invasão do Iraque sob o pretexto da exis-

2003 tência de armas químicas no país

Criação do GIT (resolução AMS 56.28)

\section{Primeira versão interina do RSI, pro- posta pelo Secretariado da OMS}

Consultas regionais e sub-regionais em relação ao documento de janeiro de 2004

Nova versão do RSI, apresentada pelo Secretariado da OMS

Primeira reunião do GIT

Nova versão do RSI, apresentada pela Presidente do GIT

Consultas regionais e sub-regionais em relação ao documento de janeiro de 2005

\section{Segunda reunião do GIT}

Negociações finais

$$
\text { Adoção do novo RSI pela AMS }
$$

\section{Legenda}

Etapas da negociação do RSI

Eventos internacionais

Resoluções da OMS 


\subsection{O destravamento das negociações}

Apesar de o processo de revisão do RSI ter iniciado em 1995, as negociações foram lentas até o início de 2003, avançando em um ritmo acelerado a partir de então. O prazo para apresentação da versão final do novo Regulamento foi estendido várias vezes, passando de 2000 para 2004 e enfim para maio de 2005, como referido anteriormente. Diversas são as razões para esse longo processo; dois eventos, contudo, impactaram significativamente as negociações, revertendo a morosidade da revisão: os ataques do 11 de setembro, seguidos dos ataques de antraz, em 2001, nos Estados Unidos; e a epidemia de SARS, que tem início final de 2002, mas alcança seu ápice em 2003.

Alguns fatores relacionados à necessidade de expandir o escopo do RSI contribuíram para o prolongamento e lentidão das negociações, como a realização do estudo piloto para avaliar a viabilidade da notificação com base em síndromes, em 1998 e, posteriormente, o desenvolvimento de um instrumento de decisão para auxiliar os Estados a identificar uma emergência de saúde pública de importância internacional.

O potencial conflito entre as normas internacionais do comércio e o novo RSI também foi um fator relevante para a morosidade da negociação (FIDLER, 2005, p.326). De 1998 a 2003, a OMS despendeu muito tempo para analisar as eventuais sobreposições entre as normas do novo Regulamento e os acordos da $\mathrm{OMC}^{44}$. A grande preocupação era compatibilizar o propósito e a aplicação mais ampla do novo RSI com as medidas sanitárias da OMC, de modo a evitar restrições desnecessárias ao comércio e garantir a proteção à saúde pública ${ }^{45}$. Discussões foram mantidas, ao longo do processo de revisão, entre os Secretariados da OMS e da OMC de modo a explorar as áreas de sinergias e os eventuais conflitos entre os acordos internacionais de comércio e o novo RSI (OMS, 2004f, p.2)

\footnotetext{
${ }^{44}$ Os principais acordos da OMC que foram considerados para analisar um possível conflito de normas com o novo RSI eram: Acordo Geral sobre Tarifas e Comércio, Acordo de Aplicação de Medidas Sanitárias e Fitossanitárias, Acordo sobre Barreiras Técnicas ao Comércio, Acordo Geral sobre Serviços, Acordo sobre os Aspectos dos Direitos de Propriedade Intelectual Relacionados ao Comércio (OMS, 2004f, p.2)

45 Dois possíveis problemas foram identificados entre o novo RSI que estava sendo negociado e os acordos de comércio internacional. Primeiramente, em em relação aos documentos de saúde pública referentes a bens e cargas de comércio internacional: enquanto o artigo 26 da versão provisória do RSI de janeiro de 2004 (OMS, 2004) proibia a exigência de documentos além daqueles de rotina exigidos em relação a bens, cargas de comércio internacional, emitidos de acordo com os acordos internacionais aplicáveis, o artigo XX (b) do Acordo Geral sobre Tarifas e Comércio permitia que os Estados Partes exigissem documentos « não rotineiros » em relação a situação de saúde pública de cargas e bens. Um segundo possível conflito decorria do fato de a OMS poder emitir recomendações temporárias ou permanentes, de acordo com os artigos 11 e 12 da versão de janeiro de 2004, as quais, apesar de não vinculantes, poderiam conflitar com as obrigações previstas nos acordos da OMC, já que os Estados Partes têm o direito implementá-las (OMS, 2004f, p.2).
} 
A lentidão das negociações, todavia, não se deve apenas a razões de ordem operacional. Percebe-se, no início do processo, uma falta de interesse dos Estados em se empenharem ativamente para discutir o RSI. Apesar do consenso quanto à necessidade de alterar o escopo do Regulamento, havia pouco interesse em priorizar o processo de revisão. Engajar os países no processo de reforma provou ser um continuo desafio (DAVIES; KAMRADT-SCOTT; RUSHTON, 2015, p. 31).

A partir de 1999, ano em que o estudo piloto concluiu que a notificação com base em síndromes não seria viável, o processo de negociação perdeu impulso, e a revisão do RSI foi obscurecida por outras preocupações de saúde pública que ganharam maior relevância no cenário internacional, como os impactos do acordo de propriedade intelectual da OMC para a saúde pública e o acesso a medicamentos pelo Sul Global (WEIR; MYKHALOVSKY, 2010, p.122). Ademais, com a nomeação de Gro Harlem Brundtland para cargo de Diretora Geral da OMS, em 1998, outros temas ganham prioridade na agenda da organização, como a adoção da primeira Convenção negociada no âmbito da OMS, a Convenção-Quadro para o Controle do Tabaco (OMS, 2003e), contribuindo para que as negociações do RSI ficassem relativamente estagnadas.

Nessa conjuntura, os atentados do 11 de setembro e os subsequentes ataques de antraz, em 2001, lançam nova luz sobre as deficiências do antigo regulamento, trazendo para o processo de revisão uma perspectiva de segurança nacional e internacional (FIDLER, 2005, p.342). A falta de interesse dos Estados para negociarem o RSI até os eventos de 2001 é apontada por um dos membros da delegação brasileira, que destaca a importância desses acontecimentos ao trazer as temáticas do bioterrorismo e biossegurança para negociação, influindo na formulação de muitos dispositivos, o que dificultou o consenso na adoção de um documento final (ENTREVISTADO 1, 2014).

Os atentados de 2001 evidenciam a importância de um sistema de alerta e vigilância sanitária em escala global para a detecção de um possível ataque de armas químicas ou biológicas, despertando a preocupação da OMS para o papel desempenhado pelos sistemas de saúde em casos de uso intencional de agentes infecciosos e tóxicos. Até a elaboração da primeira versão completa do RSI, divulgada em janeiro de 2004, constata-se, assim, a publicação de vários documentos que enquadram doenças infecciosas e preocupações com o uso intencional de agentes químicos e biológi- 
cos como as ameaças à segurança sanitária global ${ }^{46}$, sendo relatório Global defense against the infectious disease threat (OMS, 2003) um exemplo desse processo, conforme já apontado.

A OMS passa a utilizar, portanto, um discurso securitário, sob o signo da segurança sanitária mundial, que insere o RSI numa estratégia global de preparação e defesa contra propagação de doenças infecciosas, cuja origem poderia ser um ato intencional, como um evento de bioterrorismo. Essa nova percepção sobre as doenças infecciosas e a vinculação do RSI a uma retórica de segurança chama a atenção dos Estados para a importância do documento que estava sendo negociado, estimulando a vontade política dos países negociadores a se comprometerem com a revisão do RSI, o que favoreceu o avanço das negociações.

Segundo Davies, Kamradt-Scott e Rushton, o processo de revisão do RSI foi politicamente possível por meio da construção do vínculo entre segurança internacional e surtos de doenças infecciosas, o que motivou o apoio generalizado à adoção de um regime global de controle de doenças mais efetivo $(2015$, p.7). Os autores defendem que os « formuladores de normas », com destaque para o Secretariado da OMS, estavam determinados a captar esse novo discurso de segurança para promover a reforma do que ficaria conhecido como o « regime global de segurança sanitária », cuja peça fundamental seria o Regulamento revisado, sendo bem sucedidos em convencer os Estados da necessidade de se avançar na revisão do RSI.

Não obstante a aprovação da resolução de 1995 para revisar o RSI, a contínua falta de comprometimento político (e financeiro) assolou esses primeiros anos do processo de revisão. Persuadir os Estados da necessidade de uma resposta coletiva revitalizada exigiu que a equipe do Secretariado defendesse continuamente o processo de revisão, enquadrando o tema em termos de segurança nacional numa tentativa de alcançar uma priorização de alto nível ${ }^{47}$ (DAVIES; KAMRADT-SCOTT; RUSHTON, 2015, p.41, tradução nossa).

Enquanto as questões de segurança internacional despertaram a atenção política para a relevância das negociações do RSI, o surgimento da epidemia de SARS, em novembro de 2002, uma

\footnotetext{
${ }^{46}$ Destacamos os seguintes relatórios e resoluções da OMS nesse âmbito, abordados na seção anterior: relatório do Secretariado EB109/26, The deliberate use of biological and chemical agents to cause harm: public health response (OMS 2001b); a resolução do Conselho Executivo EB109. R5 de janeiro de 2002, Global public health response to deliberate use of biological and chemical agents, and radio-nuclear attacks to cause harm (OMS 2002a); o relatório do Secretariado A55/20, de abril de 2002, Deliberate Use of Biological and Chemical Agents to Cause Harms, e a emblemática resolução 55.16, de 18 de maio de 2002, intitulada Global Public Health Response to natural occurrence, accidental release or deliberate use of biological and chemical agents or radio-nuclear material that affect health (OMS 2002b).

47 Traduzido do inglês: « Notwithstanding the passage of the 1995 resolution to amend the IHR, a continuing lack of political (and financial) commitment beset these early years of the revision process. Persuading states of the need for a revitalized collective response required the secretariat team to continually make the case for the revision process, framing the issues in terms of national security in an attempt to achieve high-level prioritization ».
} 
doença desconhecida e que se propagava rapidamente por meio de viagens internacionais, demonstrou, na prática, a falta de operacionalidade do antigo RSI frente às doenças emergentes, revitalizando o processo de revisão. Dessa forma, « a SARS não apenas impulsionou a consciência da necessidade de mudanças comportamentais, mas também deu aos Estados forte incentivo para se engajar seriamente no processo de revisão do RSI e buscar institucionalizar essas mudanças comportamentais $»^{48}$ (Ibid., 2015 p.53, tradução nossa). Harlem Brundtland, que ocupava o cargo de Diretor Geral da OMS à época, declarou publicamente, em maio de 2003, que a SARS tinha passado de problema desconhecido do sul da China para uma « ameaça a saúde global » ${ }^{49}$.

O fato de a primeira versão completa do RSI surgir em janeiro de 2004 decorre, em grande medida, do impacto da epidemia de SARS no processo de revisão. A velocidade com a qual o vírus se propagou e a inépcia das obrigações internacionais existentes em prover uma estrutura para ação global impulsionaram o comitê de revisão do RSI a apresentar rapidamente um documento à AMS (YOUDE, 2011, p. 818). Como aponta um dos negociadores da delegação francesa negociadora do $\mathrm{RSI}^{50}$ :

Eu penso que entre os atentados terroristas de 2001, a ameaça bioterroristas e, posteriormente, a epidemia de SARS de 2003 houve um sentimento de perigo que conduziu, na minha opinião, à aceleração do processo de negociação. Eu penso que os Estados membros disseram que era necessário acelerar as coisas. Assim, isso conduziu efetivamente à revisão do RSI em maio de 2005 (ENTREVISTADO 2, 2015).

A crise de SARS conferiu urgência ao processo de revisão e demonstrou que uma emergência de saúde pública internacional poderia afetar não apenas a saúde humana e animal, como também impactar a estabilidade econômica e o desenvolvimento dos países (WHELAN, 2008, p. 1; OMS 2003f, p. 78) ${ }^{51}$. Destaca-se que o sentido de urgência trazido pela epidemia de SARS recrudesceu o já existente enquadramento do RSI em termos de segurança, promovido pelo Secretariado da OMS, o que facilitou também a superação de indiferenças e oposições em relação ao processo de

\footnotetext{
48 Traduzido do inglês: « SARS not only bolstered awareness of the need for behavioral changes, but it also gave states a strong incentive to engage seriously in the IHR revision process and seek to institutionalize these behavioral changes »

49 Discurso Harlem Brudtland, "SARS - A Global Threat, A Global Response", 7 de maio de 2003: http://www.who.int/dg/brundtland/speeches/2003/eucouncil sars/en/
}

${ }^{50}$ Entrevista concedida originalmente em francês: « moi, je pense entre les attentats terroristes en 2001, la menace bioterroriste et puis l'épidémie de SARS de 2003, il y a eu un sentiment de danger qui a conduit, à mon avis, à une accélération du processus de négociation. Je pense que les états membres et l'ont du se dire qu'il fallait accélérer les choses. Et donc ça a conduit effectivement à la révision du RSI en mai 2005. »

${ }^{51}$ Lee et Mckibbin (2004) fazem uma estimativa dos custos econômicos globais decorrentes da epidemia de SARS 
revisão. Nesse sentido, « a segurança proveu o arcabouço no qual o surto de SARS foi compreendido e discutido, e, por sua vez, o SARS legitimou a retórica de segurança $»^{52}$ (DAVIES; KAMRADT-SCOTT; RUSHTON, 2015, p. 56, tradução nossa).

O conceito de segurança sanitária mundial passou rapidamente a ser associado, e de forma bem sucedida, à revisão do RSI. Nesse contexto, o Secretariado enquadra cuidadosamente doenças infecciosas como um tipo particular de ameaça à segurança que requer uma resposta internacional cooperativa e institucionalizada, valendo-se do termo segurança sanitária mundial para justificar esse argumento:

A experiência compartilhada do SARS, que desencadeou um engajamento revitalizado e coletivo para a elaboração e adoção da revisão do RSI e que provocou um momento crítico na emergência de novas normas de segurança sanitária mundial, proveu uma experiência inédita que moldou o senso dos Estados quanto à obrigação às novas normas de segurança sanitária global ${ }^{53}$ (Ibid., p.73, tradução nossa).

O Secretariado emitiu um relatório, em 17 de maio de 2003, destacando a importância da epidemia de SARS para o processo de revisão do RSI (OMS, 2003c). A resolução aponta que a atual revisão buscará prover uma estrutura legal global de notificação e vigilância mais robusta, bem como um mecanismo que garanta a implementação de medidas para prevenir a propagação internacional de doenças. Afirmou que a epidemia de SARS ilustra a necessidade de um novo Regulamento e que as lições aprendidas são úteis para avaliar a capacidade global de resposta a outras ameaças de doenças infecciosas, bem como o uso de agentes com propósitos terroristas. Com base no relatório do Secretariado, a AMS emitiu a resolução 56.29, em 28 de maio de 2003 (OMS, 2003b), solicitando que o Diretor Geral levasse em consideração evidências, experiências, conhecimento e lições aprendidas durante a resposta à crise de SARS na revisão do RSI. No mesmo mês, a Assembleia Mundial da Saúde criou o grupo intergovernamental de trabalho, e o processo de revisão do RSI entrou em sua fase final de negociações, fase mais crítica e dinâmica.

\footnotetext{
52 Traduzido do inglês: « Security provided the frame within which the SARS outbreak was understood and discussed, and in turn SARS legitimized the security rhetoric »

53 Traduzido do inglês: « The shared experience of SARS, which triggered a revitalized collective engagement in the drafting and adoption of the IHR revisions and brought about a tipping point in the emergence of new global health security norms, proved a seminal experience that shaped states' sense of obligation to the new norms of global health security »
} 


\subsection{As dimensões de segurança nas negociações do RSI}

A revisão do RSI ocorreu em um contexto social de crescente securitização das doenças infecciosas, o que repercutiu nas negociações, influenciando a natureza do Regulamento final. Dentre os quatro negociadores entrevistados no âmbito desta pesquisa ${ }^{54}$, todos concordaram que, apesar de o RSI ser um documento de saúde pública, interesses de segurança estiveram presentes ao longo do processo de negociação, sobretudo na etapa final. A fim de compreender como o RSI foi negociado sob uma perspectiva securitária e em que medidas as inovações trazidas por esse novo documento incorporam preocupações de segurança, torna-se fundamental uma análise dos pontos mais polêmicos e controversos das negociações. Dada a dimensão e o propósito deste artigo, serão analisados apenas os dispositivos que permitam avaliar a influência dos temas de segurança na revisão do atual RSI.

Elementos de segurança estão presentes desde o início das negociações e são percebidos nas três versões provisórias do Regulamento. Eles podem ser identificados na definição do propósito, na definição de termos-chave, nos critérios de notificação e na tentativa de inclusão de um artigo específico para tratar de eventos relacionados ao uso acidental ou deliberado de agentes biológicos, químicos ou radio-nucleares (artigo 41 na versão de janeiro de 2004 e artigo 45 na versão de setembro de 2004).

Abaixo, um quadro comparativo demonstra a evolução dos principais artigos que envolviam questões de segurança ao longo da negociação. Esse quadro foi formulado a partir da comparação das versões provisórias disponíveis do RSI (de janeiro de 2004, setembro de 2004 e janeiro de 2005) com o Regulamento final aprovado. Optou-se por não traduzir os termos para mencioná-los da forma exata como foram apresentados às delegações negociadoras. A versão final em português dos dispositivos comparados encontra-se logo abaixo ao quadro.

\footnotetext{
${ }^{54}$ A lista dos entrevistados encontra-se no Anexo I.
} 
QUADRO 2: Evolução dos artigos do RSI

\begin{tabular}{|c|c|c|c|c|}
\hline Conceitos & Versão jan. 2004 & Versão set. 2004 & Versão jan. 2005 & $\begin{array}{l}\text { RSI final maio } \\
2005\end{array}$ \\
\hline Propósito & $\begin{array}{l}\text { « to provide securi- } \\
\text { ty against the inter- } \\
\text { national spread of } \\
\text { disease while avoi- } \\
\text { ding unnecessary } \\
\text { interference with } \\
\text { international } \\
\text { traffic » }\end{array}$ & $\begin{array}{l}\text { « to protect } \\
\text { against, control, } \\
\text { and respond to the } \\
\text { international } \\
\text { spread of disease } \\
\text { in ways that are } \\
\text { commensurate with } \\
\text { the threat to public } \\
\text { health, and which } \\
\text { would avoid unne- } \\
\text { cessary interfe- } \\
\text { rence with interna- } \\
\text { tional traffic " }\end{array}$ & $\begin{array}{l}\text { « the purpose and } \\
\text { scope of these Re- } \\
\text { gulations are to } \\
\text { prevent, protect } \\
\text { against, control, } \\
\text { and provide public } \\
\text { health responses to } \\
\text { the international } \\
\text { spread of disease } \\
\text { in ways that are } \\
\text { commensurate with } \\
\text { risks and threats to } \\
\text { public health, and } \\
\text { which avoid unne- } \\
\text { cessary interfe- } \\
\text { rence with interna- } \\
\text { tional traffic » }\end{array}$ & $\begin{array}{l}\text { «the purpose and } \\
\text { scope of these Re- } \\
\text { gulations are to } \\
\text { prevent, protect } \\
\text { against, control and } \\
\text { provide a public } \\
\text { health response to } \\
\text { the international } \\
\text { spread of disease } \\
\text { in ways that are } \\
\text { commensurate with } \\
\text { and restricted to } \\
\text { public health risks, } \\
\text { and which avoid } \\
\text { unnecessary inter- } \\
\text { ference with inter- } \\
\text { national traffic and } \\
\text { trade ». }\end{array}$ \\
\hline Doença & $\begin{array}{l}\text { « an illness that } \\
\text { presents a risk of } \\
\text { significant harm to } \\
\text { humans caused by } \\
\text { biological, chemical } \\
\text { or radio nuclear } \\
\text { sources » }\end{array}$ & $\begin{array}{l}\text { «an animal or hu- } \\
\text { man illness that } \\
\text { presents a risk of } \\
\text { significant harm to } \\
\text { humans caused by } \\
\text { biological, chemical } \\
\text { or radio nuclear } \\
\text { sources » }\end{array}$ & $\begin{array}{l}\text { « an animal or hu- } \\
\text { man illness that } \\
\text { presents a risk of } \\
\text { significant harm to } \\
\text { humans caused by } \\
\text { biological, chemical } \\
\text { or radio nuclear } \\
\text { sources » }\end{array}$ & $\begin{array}{l}\text { «an illness or me- } \\
\text { dical condition, ir- } \\
\text { respective of origin } \\
\text { or source, that pre- } \\
\text { sents or could } \\
\text { present significant } \\
\text { harm to humans» }\end{array}$ \\
\hline $\begin{array}{l}\text { Risco para a } \\
\text { saúde pública }\end{array}$ & $\begin{array}{l}\text { « an event posing a } \\
\text { serious and direct } \\
\text { threat to the health } \\
\text { of human popula- } \\
\text { tions » }\end{array}$ & Termo ausente & $\begin{array}{l}\text { « an event posing a } \\
\text { probability of inter- } \\
\text { national spread of } \\
\text { disease » }\end{array}$ & $\begin{array}{l}\text { « means a likeli- } \\
\text { hood of an event } \\
\text { that may affect ad- } \\
\text { versely the health } \\
\text { of human popula- } \\
\text { tions, with an em- } \\
\text { phasis on one } \\
\text { which may spread } \\
\text { internationally or } \\
\text { may present a se- } \\
\text { rious and direct } \\
\text { danger» }\end{array}$ \\
\hline
\end{tabular}




\begin{tabular}{|c|c|c|c|c|}
\hline Conceitos & Versão jan. 2004 & Versão set. 2004 & Versão jan.2005 & $\begin{array}{l}\text { RSI final maio } \\
2005\end{array}$ \\
\hline $\begin{array}{l}\text { Ameaça de saúde } \\
\text { pública }\end{array}$ & Termo ausente & $\begin{array}{l}\text { « a serious and } \\
\text { direct danger to the } \\
\text { health of human } \\
\text { populations » }\end{array}$ & $\begin{array}{l}\text { « a serious and } \\
\text { direct danger to the } \\
\text { health of human } \\
\text { populations » }\end{array}$ & Termo suprimido \\
\hline $\begin{array}{l}\text { Emergência de } \\
\text { saúde pública de } \\
\text { importância } \\
\text { internacional }\end{array}$ & $\begin{array}{l}\text { Termo presente, } \\
\text { porém sem uma } \\
\text { definição precisa }\end{array}$ & $\begin{array}{l}\text { « an extraordinary } \\
\text { event which is } \\
\text { determined, as } \\
\text { provided in theses } \\
\text { Regulations: (i) to } \\
\text { constitute a public } \\
\text { health threat to } \\
\text { other States } \\
\text { through } \\
\text { international spread } \\
\text { of disease and (ii) } \\
\text { to require a } \\
\text { coordinated } \\
\text { international } \\
\text { response » }\end{array}$ & $\begin{array}{l}\text { " an extraordinary } \\
\text { event which is } \\
\text { determined, as } \\
\text { provided in theses } \\
\text { Regulations: (i) to } \\
\text { constitute a public } \\
\text { health threat to } \\
\text { other States } \\
\text { through } \\
\text { international spread } \\
\text { of disease and (ii) } \\
\text { to potentially } \\
\text { require a } \\
\text { coordinated } \\
\text { international } \\
\text { response » }\end{array}$ & $\begin{array}{l}\text { " an extraordinary } \\
\text { event which is } \\
\text { determined, as } \\
\text { provided in these } \\
\text { Regulations: (i) to } \\
\text { constitute a public } \\
\text { health risk to other } \\
\text { States through the } \\
\text { international spread } \\
\text { of disease and e (ii) } \\
\text { to potentially } \\
\text { require a } \\
\text { coordinated } \\
\text { international } \\
\text { response » }\end{array}$ \\
\hline $\begin{array}{l}\text { Compartilhament } \\
\text { o de informação } \\
\text { em caso de } \\
\text { suspeita de } \\
\text { liberação } \\
\text { intencional } \\
\text { (Artigo 41/45) }\end{array}$ & $\begin{array}{l}\text { « in the context of a } \\
\text { suspect intentional } \\
\text { release of } \\
\text { biological, chemical } \\
\text { or radio nuclear } \\
\text { agent, States shall } \\
\text { immediately } \\
\text { provide to WHO all } \\
\text { relevant public } \\
\text { health information, } \\
\text { materials and } \\
\text { samples, for } \\
\text { verification and } \\
\text { response } \\
\text { purposes " }\end{array}$ & $\begin{array}{l}\text { «If a State Party } \\
\text { has evidence that } \\
\text { there has been an } \\
\text { intentional release } \\
\text { of a biological, } \\
\text { chemical, or radio } \\
\text { nuclear agent } \\
\text { within its territory, it } \\
\text { shall, consistent } \\
\text { with its security and } \\
\text { law enforcement } \\
\text { requirements, } \\
\text { provide to WHO all } \\
\text { relevant public } \\
\text { health information, } \\
\text { materials, and } \\
\text { samples for } \\
\text { verification and } \\
\text { response } \\
\text { purposes » }\end{array}$ & $\begin{array}{l}\text { «If a State Party } \\
\text { has evidence that } \\
\text { there has been an } \\
\text { intentional release } \\
\text { of a biological, } \\
\text { chemical, or radio } \\
\text { nuclear agent } \\
\text { within its territory, it } \\
\text { shall, consistent } \\
\text { with its security and } \\
\text { law enforcement } \\
\text { requirements, } \\
\text { provide to WHO all } \\
\text { relevant public } \\
\text { health information, } \\
\text { materials, and } \\
\text { samples for } \\
\text { verification and } \\
\text { response } \\
\text { purposes » }\end{array}$ & Artigo suprimido \\
\hline
\end{tabular}




\begin{tabular}{|c|c|c|c|c|}
\hline Conceitos & Versão jan 2004 & Versão set 2004 & Versão jan. 2005 & $\begin{array}{l}\text { RSI final maio } \\
2005\end{array}$ \\
\hline $\begin{array}{l}\text { Anexo } 2 \text { - } \\
\text { exemplos de } \\
\text { circunstâncias } \\
\text { que contribuem } \\
\text { para um alto } \\
\text { impacto de saúde } \\
\text { pública }\end{array}$ & $\begin{array}{l}\text { - « Release into the } \\
\text { environment of a } \\
\text { chemical or } \\
\text { radiological agent } \\
\text { that has } \\
\text { contaminated or } \\
\text { has the pontential } \\
\text { to contaminate a } \\
\text { population and/or a } \\
\text { large geographical } \\
\text { area » } \\
\text { - « Is the event } \\
\text { know or suspected } \\
\text { to be the result of } \\
\text { an intentional or } \\
\text { accidental release } \\
\text { of chemical, } \\
\text { radionuclear or } \\
\text { biological agent? » }\end{array}$ & $\begin{array}{l}\text { - « Release into the } \\
\text { environment of a } \\
\text { chemical or } \\
\text { radiological agent } \\
\text { that has } \\
\text { contaminated or has } \\
\text { the pontential to } \\
\text { contaminate a } \\
\text { population and/or a } \\
\text { large geographical } \\
\text { area » } \\
- \text { « Is the event know } \\
\text { or suspected to be } \\
\text { the result of an } \\
\text { intentional or } \\
\text { accidental release of } \\
\text { chemical, } \\
\text { radionuclear or } \\
\text { biological agent? » }\end{array}$ & $\begin{array}{l}\text { - « Release into the } \\
\text { environment of a } \\
\text { chemical or } \\
\text { radiological agent } \\
\text { that has } \\
\text { contaminated or } \\
\text { has the pontential } \\
\text { to contaminate a } \\
\text { population and/or a } \\
\text { large geographical } \\
\text { area » } \\
- \text { « Is the event } \\
\text { know or suspected } \\
\text { to be the result of } \\
\text { an intentional or } \\
\text { accidental release } \\
\text { of chemical, } \\
\text { radionuclear or } \\
\text { biological agent? » }\end{array}$ & $\begin{array}{l}\text { «Spread of toxic, } \\
\text { infectious or } \\
\text { otherwise } \\
\text { hazardous } \\
\text { materials that may } \\
\text { be occurring } \\
\text { naturally or } \\
\text { otherwise that has } \\
\text { contaminated or } \\
\text { has the potential to } \\
\text { contaminate a } \\
\text { population and/or a } \\
\text { large geographical } \\
\text { area ». }\end{array}$ \\
\hline
\end{tabular}

\begin{tabular}{|c|c|c|c|c|c|}
\hline & Propósito & Doença & $\begin{array}{l}\text { Risco para a } \\
\text { saúde pública }\end{array}$ & $\begin{array}{l}\text { Emergência de } \\
\text { saúde pública de } \\
\text { importância } \\
\text { internacional }\end{array}$ & Anexo 2 \\
\hline $\begin{array}{l}\text { RSI (versão } \\
\text { em } \\
\text { português) }\end{array}$ & $\begin{array}{l}\text { «prevenir, } \\
\text { proteger, } \\
\text { controlar e dar } \\
\text { uma resposta } \\
\text { de saúde } \\
\text { pública contra } \\
\text { a propagação } \\
\text { internacional } \\
\text { de doenças, de } \\
\text { maneiras } \\
\text { proporcionais e } \\
\text { restritas aos } \\
\text { riscos para a } \\
\text { saúde pública, } \\
\text { e que evitem } \\
\text { interferências } \\
\text { desnecessárias } \\
\text { com o tráfego e } \\
\text { o comércio } \\
\text { internacionais } \\
\text { » }\end{array}$ & $\begin{array}{l}\text { «significa } \\
\text { uma doença } \\
\text { ou agravo, } \\
\text { independente } \\
\text { mente de } \\
\text { origem ou } \\
\text { fonte, que } \\
\text { represente ou } \\
\text { possa } \\
\text { representar } \\
\text { um dano } \\
\text { significativo } \\
\text { para seres } \\
\text { humanos » }\end{array}$ & $\begin{array}{l}\text { « a } \\
\text { probabilidade } \\
\text { de um evento } \\
\text { que possa } \\
\text { afetar } \\
\text { diversamente a } \\
\text { saúde de } \\
\text { populações } \\
\text { humanas, com } \\
\text { ênfase } \\
\text { naqueles que } \\
\text { possam se } \\
\text { propagar } \\
\text { internacionalme } \\
\text { nte, ou possa } \\
\text { apresentar um } \\
\text { perigo grave e } \\
\text { direto » }\end{array}$ & $\begin{array}{l}\text { « um evento } \\
\text { extraordinário que, } \\
\text { nos termos do } \\
\text { presente } \\
\text { Regulamento é } \\
\text { determinado como: } \\
\text { (i) constituindo um } \\
\text { risco para a saúde } \\
\text { pública para outros } \\
\text { Estados, devido à } \\
\text { propagação } \\
\text { internacional de } \\
\text { doença e (ii) } \\
\text { potencialmente } \\
\text { exigindo uma } \\
\text { resposta } \\
\text { internacional } \\
\text { coordenada » }\end{array}$ & $\begin{array}{l}\text { - Propagação } \\
\text { de materiais } \\
\text { tóxicos, } \\
\text { infecciosos } \\
\text { ou de por } \\
\text { alguma outra } \\
\text { razão } \\
\text { perigosos, de } \\
\text { origem } \\
\text { natural ou } \\
\text { não, que } \\
\text { tenham } \\
\text { contaminado } \\
\text { ou tenham o } \\
\text { potencial de } \\
\text { contaminar } \\
\text { uma } \\
\text { população e/ } \\
\text { ou uma } \\
\text { grande área } \\
\text { geográfica. » }\end{array}$ \\
\hline
\end{tabular}


Expandir a finalidade e a aplicação do RSI era uma demanda comum dos países, porém como definir e delimitar um novo escopo foi um tema controverso sobre o qual todas as regiões se manifestaram. Na versão divulgada em janeiro de 2004, percebe-se que a finalidade do Regulamento é definida em termos de «prover segurança contra a propagação internacional de doenças» (OMS, 2004), o que provocou críticas por parte de alguns Estados, notadamente dos países da América do Sul, que defendiam que o propósito do novo regulamento deveria ser « reduzir o risco de propagação internacional de doenças » (OPAS, 2004).

Estreitamente vinculado a redefinição do escopo do RSI estava o conceito dos termos de saúde pública adotados pelo Regulamento. Era consenso entre os Estados a necessidade de moverse para além de uma abordagem baseada em doenças específicas, conforme era previsto no RSI de 1969, bem como a importância de uma estrutura que abarcasse um número maior de riscos à saúde pública, incluindo doenças ainda não previstas. Contudo, como delimitar essa expansão e dotar-lhe de operacionalidade foram pontos nevrálgicos que perduraram durante toda negociação, visto que envolviam não somente a substituição de uma lista específica de doenças, mas a própria definição de termos-chave que delimitariam a aplicação do Regulamento, notadamente os conceitos de « doença », « evento », « risco para a saúde pública » e a criação de uma nova categoria conceitual «emergência de saúde pública de importância internacional » (ESPII), além da formulação de um instrumento de notificação (OMS, 2005).

Ao analisar os documentos oficiais referentes ao processo de revisão, sobretudo as versões provisórias e os comentários individuais enviados pelos Estados, percebe-se a utilização de um vocabulário típico da área de segurança na definição de conceitos de saúde pública. No prefácio da primeira versão, de janeiro de 2004, o Secretariado aponta a presença de novos conceitos no documento, fazendo referência ao fato de que alguns desses já foram refletidos em resoluções prévias da AMS, notadamente as resoluções 48.7, 54.14, 55.16, 56.28 e 56.29, já mencionados neste artigo ${ }^{55}$. Nota-se que essas resoluções estão voltadas aos novos riscos globais à saúde, fazendo referência ao uso deliberado de agentes biológicos, químicos e radio-nucleares e ao potencial uso de tais agentes com propósitos terroristas.

\footnotetext{
55 Resolução 48.7: Revision and Updating of the International Health Regulations (OMS, 1995a)

Resolução 54.14: Global Health Security - epidemic alert and response (OMS, 2001)

Resolução 55.16: Global public health response to natural occurrence, accidental release or deliberate use of biological and chemical agents or radionuclear material that affect health (OMS, 2002b)

Resolução 56.28; Revision of the International Health Regulations (OMS, 2003a)

Resolução 56.29: Severe Acute Respiratory Syndrome (SARS) (OMS, 2003b)
} 
Conforme apresentado no quadro comparativo, na primeira versão do RSI, encontramos, « doença » definida como algo que « apresenta um risco de dano significativo aos humanos causado por fontes biológicas, químicas e radio-nucleares 》 e 《 risco para a saúde pública » como um « evento que impõe uma ameaça séria e direta à saúde das populações humanas » (OMS, 2004). Apesar de não constar uma definição precisa para ESPII, a versão de janeiro já introduz o termo, estabelecendo que os Estados deveriam notificar todos os eventos que potencialmente pudessem constituir uma ESPIl, ocorrendo em seu território, « independentemente da causa, incluindo aqueles associados ao uso acidental, natural ou suspeito de patógenos e materiais químicos e radio- nucleares » (Ibid, p.2), fazendo referência direta à resolução da AMS 55.16.

No documento divulgado pela OMS em relação às consultas regionais, que reúne as posições dos Estados membros sobre as principais mudanças introduzidas na primeira versão, a definição desses termos aparece como um dos pontos mais questionados pelas regiões (OMS, 2004c). Do ponto de vista geral, há apoio para a inclusão de termos adicionais, desde que estes sejam definidos, sempre que possível, de forma mais consistente com a linguagem de saúde pública. Nota-se, por exemplo, que a definição de doenças, ao incluir explicitamente « fontes biológicas, químicas e radio-nucleares », está mais próxima de um sentido de segurança internacional para doença, muito distinto de uma definição pautada em concepções médicas, que convencionalmente se baseia em patologias do corpo humano (WEIR, 2015, p. 24).

Nas reuniões de consultas regionais organizadas pela Organização Pan-Americana de Saúde (OPAS) na América do Norte, América Central e na América do Sul, após a divulgação da versão de janeiro de 2004, percebe-se uma divergência de opiniões das regiões quanto à definição desses termos. Os centro-americanos e, principalmente, os países sul-americanos, em reunião no Rio de Janeiro, apontaram para a ambiguidade de alguns conceitos e a utilização de terminologia não própria de saúde pública, demandando uma maior precisão na definição e adequação dos termos ao uso comum e reconhecido no campo da saúde pública (OPAS 2004a).

O posicionamento dos países participantes da reunião no Canadá, todavia, não segue a mesma linha dos países da América do Sul (OPAS, 2004b). Nessa reunião, ao se discutir o conceito de ESPII, propõe-se a definição: « uma emergência da saúde pública de importância internacional é um risco de saúde pública que representa uma ameaça a outros Estados através da propagação internacional, para a qual se estabelece, de acordo com esse Regulamento, a necessidade de extraor- 
dinária resposta internacional coordenada para a efetiva contenção $»^{56}$ (Ibid., p.2, tradução nossa), a qual se aproxima mais de uma visão securitária, como a próprio uso do termo « ameaça » evidencia. A utilização de uma terminologia de segurança na definição de conceitos de saúde pública centrais para o Regulamento era abertamente defendida, sobretudo, pelos Estados Unidos, que buscavam, sempre que possível, inserir objetivos de segurança no texto do RSI (ENTREVISTADO 1, 2014).

O Japão foi reticente em relação à menção explícita a fontes químicas, biológicas e radionucleares na definição de doenças. Em seus comentários individuais, apesar de concordar que o princípio fundamental do RSI deveria ser o de " prover a segurança » contra a propagação internacional de doenças, o Japão afirmou ter dificuldades em aceitar a inclusão de doenças causadas por agentes químicos e materiais radio-nucleares como parte do escopo do RSI (JAPÃO, 2004) ${ }^{57}$, defendendo que a menção a tais eventos não deveriam constar na definição de doenças e de ESPII. Incluir emergências de saúde pública associadas a materiais biológicos, químicos ou radio-nucleares parece exceder o princípio fundamental do RSI, bem como exigiria muitas mudanças, em âmbito doméstico e internacional, o que poderia prejudicar a imediata implementação do Regulamento, vista como prioridade pelo Japão (JAPAO, 2004).

Os países europeus, por sua vez, concordaram com a ampliação do escopo do RSI de modo a abarcar eventos de doenças de origem biológica, química e radio-nuclear, bem como aqueles de origem desconhecidas. No entanto, os países demonstraram preocupação com fato de o RSI, ao cobrir eventos de tal natureza, gerar duplicação de esforços e conflitar com a competência de outras agências, sobretudo em relação ao papel da OMS na resposta a tais eventos (EURO, 2004; COMUNIDADE EUROPEIA, 2004). A Noruega demonstra um posicionamento semelhante em seu comentário individual, no qual apoia a ampliação do escopo do RSI, porém, em se tratando de surtos de doenças decorrentes de eventos químicos ou radio-nucleares, aponta que não há grande necessidade de estender a aplicação do Regulamento de modo a cobrir tais eventos, visto que estes podem ser melhor enfrentados por outras instituições (NORUEGA, 2004).

Nesse debate sobre a inclusão de agentes químicos, biológicos e nucleares, bem como sobre a inclusão do controverso artigo 41, discutido adiante, os escritórios regionais da África (AFRO) e

\footnotetext{
56 Traduzido do inglês: «A Public Health Emergency of International concern is a public health risk that represents a threat to other States through international spread for which it is determined, in accordance with these Regulations, that there is a need for [extraordinary] coordinated international response for effective containment. »

${ }^{57}$ Além das reuniões de consultas regionais, alguns países produziram relatórios individuais em 2004, em que constam comentários sobre a primeira versão do RSI e propostas para a revisão, com base nos quais é possível observar um posicionamento mais claro de alguns países. Esses documentos estão disponíveis no site da OMS, acessado em dezembro de 2014: http://www.who.int/ihr/revisionprocess/commentsother1/en/
} 
da região do Mediterrâneo Oriental (EMRO) não se pronunciaram explicitamente (AFRO, 2004; EMRO 2004) em suas consultas regionais. A região do Pacífico Ocidental (WPRO) mostrou-se mais dividida, com alguns países defendendo uma abordagem ampla do RSI e outros apontando que o Regulamento deveria ser aplicado apenas em caso de doenças infecciosas, excluindo as doenças decorrentes do uso de agentes biológicos, químicos ou radio-nucleares (WPRO, 2004). O escritório regional do Sudeste Asiático (SEARO) reportou a mesma divisão de opiniões entre seus países membros, não chegando a um consenso quanto à inclusão de eventos químicos e radio-nucleares e de doenças causadas por liberações intencionais de tais agentes (SEARO, 2004) .

Percebe-se, portanto, que desde a primeira versão completa do RSI, a definição de conceitos que redimensionam o escopo de aplicação do Regulamento, com destaque para a definição de doenças, demonstrou-se problemática, principalmente por compreender riscos e eventos que recaem no âmbito de segurança internacional. Conforme destacado por um dos entrevistados: « Havia implicações de segurança implícitas nas propostas de um escopo que cobrisse todos os riscos, visto que este trazia para o Regulamento o potencial para detectar, notificar e responder a eventos nucleares e de bioterrorismo» $^{58}$ (ENTREVISTADO 4, 2016).

Ampliar o escopo do RSI de modo a abarcar possíveis problemas de segurança representaria vincular o Regulamento a temas que incidem na competência de outros agências internacionais, como a Agência Internacional de Energia Atômica (AIEA). Os Estados expressaram essa preocupação com um possível conflito de normas internacionais que, além de provocar a duplicação de esforços entre diferentes organizações, poderia desvirtuar a OMS de sua missão principal, a promoção da saúde pública (OMS, 2004c, p2). Esse debate intensifica-se ao se discutir o polêmico artigo 41 da versão de janeiro de 2004, posteriormente artigo 45 na versão de setembro de 2004.

Esse artigo está diretamente relacionado à expansão do escopo do RSI e foi um dos dispositivos mais controversos de toda negociação, pois determinava o compartilhamento de informações dos Estados com a OMS em caso de suspeita de liberação intencional de agentes químicos, biológicos ou materiais radio-nucleares. Tal artigo previa, assim, que « no contexto de uma suspeita de liberação intencional de agentes biológicos, químicos ou radio-nuclear, os Estados devem imediatamente fornecer a OMS toda informação de saúde pública relevante, materiais e amostras para verificação e objetivos de respostas » (OMS, 2004), isso independentemente se o evento tenha causado qualquer impacto para a saúde pública. Nota-se que este dispositivo está articulado à definição de

\footnotetext{
58 Entrevista concedida originalmente em inglês: « There were security implications implicit in the "all hazards" scope of the proposals, as this carried the potential to capture the detection and reporting of, and responses to, nuclear events and bio-terrorism within the Regulations ».
} 
doença e à obrigação de notificar eventos que possam constituir uma ESPII, independentemente da causa ou origem, bem como ao Anexo 2, que incluía como um dos critérios para notificação de doenças a « liberação no meio-ambiente de agente químico ou radio-nuclear que tenha contaminado ou tenha o potencial para contaminar um população ou uma ampla área geográfica » (OMS, 2004).

$\mathrm{O}$ artigo 41, presente nas três versões provisórias, demonstra uma clara vontade de vincular o RSI a temas de segurança internacional, uma vez que obrigar os Estados a aplicar o Regulamento em contextos de liberação intencional agentes biológicos, químicos e radio-nucleares significa inserir o RSI como um instrumento de defesa a atos de terrorismo biológico e uso de armas químicas. Dessa forma, esse dispositivo reforça as discussões em torno da definição de conceitos como « doença », ESPII e critérios para notificação, bem como os questionamentos sobre qual a competência da OMS para identificar e responder a eventos de origem não patogênica e intencionalmente causados.

O debate sobre a referência ou não a liberações intencionais de agentes químicos, radio-nucleares ou infecciosos no RSI provocou divergências de posições entre os países, o que pode ser percebido desde os primeiros documentos referentes às consultas regionais e aos comentários individuais dos Estados. No decorrer da revisão, essa temática polarizará os países em dois grupos: os países que buscavam usar a saúde pública como um meio de fortalecer a segurança internacional, expandindo, por exemplo, o papel da OMS na resposta ao terrorismo não convencional, e os Estados que concebiam a saúde como uma área pacífica de cooperação internacional (TUCKER, 2005, 342). Os Estados que defendiam a expansão do escopo do RSI de modo a abarcar uso intencional de agentes tóxicos e infecciosos argumentavam que a OMS deveria ajudar os países a detectar e a investigar suspeitas de liberação intencional de tais agentes para executar uma resposta de saúde pública adequada (EUA, 2004).

Dentre os países que defendiam essa posição, destacamos os EUA, que buscaram fortalecer elementos de segurança nas versões provisórias do RSI (WEIR, 2015, p.24). Em seus comentários iniciais sobre a revisão, de março de 2004, fica claro esse posicionamento dos EUA na defesa da manutenção do artigo 41, chegando a propor a inclusão de um anexo para temas relacionados à liberação intencional, no qual constaria, por exemplo, uma definição operacional do que constitui uma « suspeita de liberação intencional », o que justificaria a notificação ao Secretariado da OMS, ou outra ação sob o artigo 41 (EUA, 2004, p. 6). Em tal anexo estariam presentes também os critérios ou parâmetros para determinar se a notificação seria realizada por ser um tema de interesse de saúde pública internacional ou de potencial impacto de saúde pública, o que poderia compreender também 
considerações de segurança nacional (Ibid.). Os EUA sugeriram ainda expandir as atividades da OMS em relação ao artigo 41 de modo a prover um papel facilitador ou consultivo ao Secretariado, por meio do qual ele poderia, caso fosse solicitado, assistir os Estados-membros na detecção, investigação e confirmação de uma liberação intencional, bem como na resposta de saúde pública a tais eventos (Ibid., p.3).

$\mathrm{Na}$ mesma linha argumentativa, os EUA propõem que o conceito de ESPII deveria compreender não somente os acidentes ocorridos de forma natural, mas também os eventos intencionais, bem como o conceito de « risco de saúde pública », o qual deveria ser alterado para incluir « a possibilidade de um evento ser intencional e também de ocorrência natural» (EUA, 2004). Nos comentários de abril de 2004, percebe-se que a temática suscitada pelo artigo 41 ainda ocupa papel central, e os EUA chegam a propor uma reformulação do artigo de modo que suspeitas de uma ESPII, decorrente de um ato intencional, devessem ser imediatamente notificadas à OMS pelo Estado onde o evento ocorre ou onde pessoas afetadas são identificadas. Nesse caso, se o Estado solicitar, a OMS poderia fornecer uma assistência técnica e consultiva (EUA, 2004a, p. 24).

Diante dos comentários e propostas feitas pelos Estados Unidos, evidencia-se o interesse norte-americano de inserir o RSI no campo de segurança internacional, buscando trazer uma abordagem securitária para os dispositivos do Regulamento, vinculando-o a temáticas de biossegurança e bioterrorismo. Essa posição americana foi apoiada por países, como o México, que defendeu a manutenção do artigo 41 e das provisões do RSI em relação a casos suspeitos de liberação intencional (MEXICO, 2004).

Em entrevista realizada com um dos membros da delegação brasileira, o entrevistado afirma que temas de segurança, como biossegurança e bioterrorismo:

Permeou todo o tempo [as negociações], os EUA quis trazer todo tempo, primeiro pela questão da ameaça e perdeu, quis trazer para dentro do conceito do risco de saúde pública, conseguindo ai introduzir uma válvula que permite incluir, o que não é nenhum problema, pois risco de saúde pode compreender uma ameaça de bioterrorismo, se for em escala internacional é um risco de saúde pública, mas eles queriam destacar isso. E ao final, eles quiseram trazer isso como questão fundamental para considerar um evento de importância internacional voltada não exclusivamente, mas prioritariamente para eventos intencionais. (ENTREVISTADO 1, 2014)

Em contraposição aos EUA, estavam o Irã e os países da América do Sul, com destaque para a posição do Brasil, que desde o início das negociações se demonstrou contrário à interferência de objetivos de segurança em um documento de saúde pública (ENTREVISTADO 1, 2014). No decorrer das negociações, esses países contaram com o apoio de Estados de outras regiões, formando uma oposição mais sólida contra a inclusão de dispositivos que vinculem o RSI a casos 
de suspeita de liberação de agentes químicos, biológicos e radio-nucleares. Chazournes (2005) destaca ainda que Estados do Mediterrâneo Oriental e da África quiseram evitar todo risco de utilização do RSI a outros fins notadamente políticos.

De acordo com Tucker (2005), o grupo de países que se opunham ao artigo 41, o faziam por várias razões. Além de já existirem outras organizações que lidam com casos de uso intencional de agentes tóxicos e infecciosos, o que resultaria num conflito de competência com a OMS, incluir a liberação de agentes de destruição em massa seria divergir qualitativamente do foco histórico do regulamento em doenças infecciosas de origem natural. Além disso, expandir o escopo do RSI para cobrir possíveis casos de bioterrorismo, o que estava implícito no artigo 41, poderia envolver a OMS em questões de segurança internacional que excedessem seu mandato e expertise.

Destaca-se que a AIEA foi muito crítica à versão do RSI de janeiro de 2004, apontando a ausência de competência da AMS para adotar regulamento referente a materiais radiológicos e nucleares e seu uso como armas (WEIR, 2015, p.25). Dessa forma, a própria AIEA questiona a necessidade do artigo 41, afirmando que além de esse dispositivo violar as previsões de liberações planejadas e controladas de materiais líquidos e gasosos que se originam de atividades nucleares regulares como práticas legítimas, dentro de limites autorizados, aponta que esse tipo de assunto já é tratado por outros regimes internacionais, mencionando, por exemplo, a Convenção para Proteção Física de Materiais Nucleares, adotada em 1979 no âmbito da Agência (AIEA, 1979) ${ }^{59}$. Ademais, em relação à notificação e assistência, em caso de acidente ou emergência radiológica, a AIEA afirma que já dispõe de instrumentos para regular esse campo, como Convenção sobre Assistência em Caso de Acidente Nuclear ou Emergência Radiológica de 1986.

O conteúdo do artigo 41 reflete-se em outras partes do Regulamento, como no Anexo 2, em que consta um algoritmo com os critérios para auxiliar os Estados na notificação de uma potencial ESPII. Desde a primeira versão provisória, um dos exemplos para identificar se um surto de doença é não usual e inesperado é a resposta à pergunta « este evento é conhecido ou suspeito de ser o resultado de uma liberação intencional ou acidental de agentes químicos, radio-nucleares ou biológicos? » (OMS, 2004). A inclusão desse exemplo para facilitar a utilização do algoritmo também será contestada pelos países que se opõem ao artigo 41 .

\footnotetext{
59 « Com relação aos atos 'intencionais’ e o fornecimento de informação concernente a tais atos a uma organização internacional e/ou Estados Partes, deve-se notar que esse tema é tratado no contexto das propostas de emendas à Convenção sobre Proteção Física de Materiais Nucleares, adotadas sob o auspício da AIEA em 26 de Outubro de 1979 »(OMS, 2004d).
} 
Com base nos documentos produzidos nas consultas regionais e nos comentários e propostas individuais enviadas por alguns países sobre a revisão, o Secretariado da OMS apresenta uma versão completa revisada do RSI em 30 de setembro de 2004 (OMS, 2004b), que será o texto base de negociação no âmbito do grupo intergovernamental de trabalho, a partir de novembro do mesmo ano.

Essa versão revisada apresenta algumas mudanças importantes. Apesar das críticas dos países em relação à não utilização de uma terminologia própria de saúde pública na definição dos conceitos do RSI, o termo « risco de saúde pública » foi substituído pelo termo " ameaça de saúde pública » (public health threat), definido como « um perigo sério e direto à saúde das populações humanas »(OMS, 2004b). Esse termo está presente ao longo de todo texto em vários dispositivos, como na definição de «inspeção», " contaminação », " infecção », « recomendações temporárias », no propósito do RSI e na definição específica da categoria « emergência de saúde pública de importância internacional », que até então não havia sido apresentada (2004b). Uma ESPII, nos termos dessa versão, « significa um evento extraordinário, determinado pelo Regulamento: a) que constitui uma ameaça de saúde pública aos outros Estados através da propagação internacional da doença e b) requer uma resposta internacional coordenada » (Ibid, p. 7). Destaca-se que essa definição apresentada é muito similar à proposta de definição sugerida pelos países na reunião regional na América do Norte em junho no Canadá ${ }^{0}$.

A inclusão do termo « ameaça de saúde pública » em vários artigos na versão de setembro foi muito criticada no curso das negociações por vários países, os quais viam a inserção dessa expressão em um documento de saúde pública como uma interferência explícita de interesses de segurança, trazendo uma lógica ameaça/defesa para o RSI. De acordo com o integrante da delegação brasileira negociadora do RSI:

Nós identificamos que outros países tiveram outras estratégias de atuação que terminaram modificando os documentos preparatórios da OMS, aí citando claramente os EUA, que conseguiram, não sabemos por que estratégias, modificar os documentos preparatórios da OMS, o que não era, o que não foi colocado como possibilidade para todos os países. Quando nós trabalhamos no documento de janeiro de 2004, constava "risco de saúde publica", que deveria ser o norte de todo o regulamento, no texto que foi para negociação, salve engano, no texto do Conselho Diretor de 2005, que iria já para a assembleia, passando pelas reuniões intergovernamentais, mudava o termo para "ameaça de saúde pública".

Ameaça de saúde pública, todos que trabalham nessa área sabem que é um termo muito usado em outros fóruns, como o fórum de convenção de armas químicas e biológicas, e que tem muito

\footnotetext{
60 Conforme consta no documento resultante das consultas na América do Norte, no Canadá: « uma emergência da saúde pública de importância internacional é um risco de saúde pública que representa uma ameaça a outros Estados através da propagação internacional, para a qual se determina, de acordo com esse Regulamento, que há a necessidade de extraordinária resposta internacional coordenada para a efetiva contenção » (OPAS, 2004b, p.2)
} 
mais a ver com segurança do que com saúde pública e, como nós tivemos a oportunidade de participar da reunião sub-regional da América do Norte, vimos que isso foi claramente defendido lá pelos EUA e óbvio que seguido por Canadá e México, que propunham a modificação desse termo (ENTREVISTADO 1, 2014).

Ainda segundo o entrevistado, o debate gerado pela inclusão desse termo acentuou a polarização nas negociações, que já se formava devido ao controverso artigo 41 . O compartilhamento de informações em caso de uso intencional de agentes químicos, biológicos e materiais radio-nucleares permanece na versão revisada de setembro, previsto agora no artigo 45:

Se um Estado Parte tem evidência de que houve uma liberação intencional de um agente biológico químico ou radio-nuclar em seu território, ele deve, em conformidade com seus requisitos de segurança e aplicação da lei, prover a OMS com toda informação de saúde pública relevante, materiais e amostras para verificação e resposta ${ }^{61}$ (OMS, 2004b, p.27, tradução nossa).

Na primeira reunião do GIT, em novembro de 2004, fica clara a oposição entre dois grupos de países: de um lado temos os Estados interessados em inserir uma dimensão securitária no RSI, com destaque para os Estados Unidos, que passam a contar, quase sempre, com o apoio da Comunidade Europeia, Canadá e México; do outro os países que objetavam a utilização de termos não tradicionais de saúde pública, como « ameaça » - defendendo a utilização de « risco de saúde pública » - e que se opunham à inclusão do artigo 45, como a América do Sul, Irã e China, que contavam com o apoio dos Estados do Mediterrâneo Oriental (ENTREVISTADO 1, 2014; WEIR, 2015, p.25).

Nessa reunião, ao se debater o artigo 45, o Brasil, apoiado pelos países da América Latina, e o Irã, apoiado pelos 46 membros da região do Mediterrâneo Oriental, sugerem a supressão completa do dispositivo. Contrapondo-se diametralmente à posição do Brasil e Irã, encontramos a Europa e os Estados Unidos. A Comunidade Europeia e seus 25 membros, apoiados por Bulgária e Romênia, propõem uma alteração de forma a incluir que, em caso de evidência de que houve liberação intencional de agentes biológicos, químicos e radio-nucleares, os Estados deverão, de acordo com sua segurança nacional e internacional, bem como os requisitos de aplicação da lei, fornecer toda informação de saúde pública relevante, materiais e amostras a OMS. Destaca-se que a região africana, representada por Gana, propõe uma emenda similar à apresentada pela Comunidade Europeia (OMS, 2004e, p. 26). Até então, com base na análise dos documentos oficiais, os países africanos não haviam se manifestado explicitamente sobre essa temática, levantando sempre questões relativas à soberania e à implementação das capacidades básicas de vigilância e resposta.

61 Traduzido do inglês: « If a State Party has evidence that there has been an intentional release of a biological, chemical or radio-nuclear agent within its territory, it shall, consistent with its security and law enforcement requirements, provide to WHO all relevant public health information, materials and samples, for verification and response purposes » 
Os EUA, por sua vez, apresentam uma proposta de emenda ao artigo ainda mais ousada, buscando aumentar a autonomia do Estado em caso de uso intencional de tais agentes. Os EUA defendem que os Estados devem notificar a OMS em caso de evidência e de suspeita de utilização intencional de agentes biológicos, químicos e radio-nucleares que possam constituir uma ESPII, fornecendo a OMS toda informação de saúde pública relevante, materiais e amostras ou resultados laboratoriais para verificação e reposta, de acordo com seus requisitos de segurança e de aplicação da lei ${ }^{62}$. Nessa situação, os EUA consideram que a OMS somente se envolverá se o Estado solicitar sua assistência; caso não o faça, este detém a prerrogativa de responder a tais eventos, devendo apenas manter a organização informada das medidas tomadas para mitigar os efeitos do uso de tais agentes e para prevenir a propagação desses efeitos internacionalmente (Ibid.).

Na primeira reunião do GIT, a polarização, sobretudo em relação ao artigo 45, provocou um impasse, levando à suspensão das negociações, sendo uma nova reunião agendada para fevereiro de 2005:

Isso (artigo 45) foi responsável por travar discussões intergovernamentais, por exemplo, uma das reuniões intergovernamentais durou duas semanas, exatamente por conta desse tipo de negociação, que por um lado ela foi facilitada por nós termos consenso regional (América do Sul), mas por outro foi dificultada por mecanismos outros, ao nosso ver, não legítimos, de interferência nas posições globais (ENTREVISTADO 1, 2014).

Dentre os principais temas que estavam pendentes e que precisavam ainda ser discutidos para alcançar um consenso, Mary Whelan, Presidente do GIT, destaca: encontrar o equilíbrio entre as prerrogativas da OMS e questões que remetem à soberania dos Estados; a inclusão do respeito aos direitos humanos na implementação do RSI; o desenvolvimento de capacidades básicas de vigilância e resposta em saúde pública; e temas relacionados à ampliação do escopo do Regulamento e à definição e determinação de uma ESPII. Whelan (2008, p. 8-9) aponta, que este último tópico remetia a questões sobre o papel do RSI em caso de uso deliberado de agentes químicos, biológicos e radio-nucleares, bem como a problemas decorrentes das limitações dos acordos sobre controle de armas, em particular a Convenção sobre Armas Biológicas (OPWC, 1972).

A negociação de dispositivos que denotam a interferência de interesses não específicos de saúde pública, notadamente os de segurança, permanecerá como um dos pontos mais controversos

\footnotetext{
62 Informação original em inglês: « If a State Party suspects or has evidence that there has been an intentional release of a biological, chemical or radionuclear agent within its territory, which might constitute a public health emergency of international concern, it shall notify WHO in accordance with article 5 and, subject to its security and law enforcement requirements, provide to WHO all relevant public health information, materials and samples or laboratory results, for verification and response purposes. In situations where State Parties do no request WHO assistance, the State Party shall keep WHO apprised in a timely manner of steps taken to mitigate the effects of the intentional release and to prevent further spread of those effects internationally » (OMS, 2004e, p. 26)
} 
na etapa final de revisão, responsável por estender as negociações até maio de 2005. Whelan, ao destacar os pontos específicos e de extrema relevância nas negociações finais do RSI ${ }^{63}$, coloca em evidência a problemática de questões concernentes a outros regimes internacionais influenciarem as normas do Regulamento e determinarem o curso das negociações:

A presença de outras organizações internacionais como observadores ilustraram o fato de que alguns dos temas mais difíceis eram relacionados a áreas fora da saúde pública, incluindo comércio internacional e controle de armas. Foi importante que o grupo intergovernamental de trabalho estivesse consciente desses temas mas que não deixassem que eles influenciassem excessivamente ou determinassem o curso das negociações.

Houve temas políticos às margens das negociações, os quais raramente eram sequer chamados pelos seus nomes, mas estiveram sempre presentes. As delegações tinham que ser claras em seu objetivo primordial - era este buscar temas que não poderiam avançar e que tinham implicações muito além do escopo do RSI ou o objetivo era lidar pragmaticamente com as prováveis ameaças à saúde? ${ }^{64}$ (WHELAN, 2008, p.11, tradução nossa)

No intervalo entre as reuniões é divulgado o relatório do Secretário Geral das Nações Unidas, High Level Panel on Threats Challenges and Change, de dezembro de 2004, que avança a perspectiva de segurança sobre as negociações do RSI. De acordo com o relatório, o CS da ONU deveria consultar o Diretor Geral da OMS para estabelecer os procedimentos necessários para atuarem conjuntamente em evento suspeito de doença infecciosa ${ }^{65}$, cabendo ao Diretor Geral da OMS manter o Conselho de Segurança (CS) informado em caso de suspeita de surtos de doenças infecciosas, sejam estes de origem natural ou causados intencionalmente pelo uso de agentes infecciosos (ONU; 2004, p.17). Ademais, o CS poderia recorrer a especialistas, que reportariam diretamente ao Conselho, para apoiar os trabalhos da OMS, e, se o RSI em vigor não prover adequado acesso às investigações da OMS e uma resposta coordenada, o CS deveria estar preparado a exercer a greater compliance nessa área (ONU, 2004, parágrafo 144).

${ }^{63}$ Documento enviado pela embaixadora da Irlanda na Áustria, Mary Whelan, comentando o processo de revisado do RSI, quando lhe foi solicitada uma entrevista sobre o processo de negociação.

64 Traduzido do inglês: «The presence as observers of other intergovernmental organizations illustrated the fact that some of the more difficult issues related to areas outside the health sector including international trade and arms control. It was important that the IGWG be aware of these issues but not allow them to overly influence or determine the course of the negotiations. There were political issues on the fringes of the negotiations which were seldom if ever called by their name but were ever-present. Delegations had to be clear on their prime objective - was it to pursue issues which could not be advanced and which had implications far beyond the scope of the IHR or was it to deal pragmatically with likely threats to health?»

65 O painel sugere ainda que: "O Conselho de Segurança deveria consultar o Diretor Geral da OMS para estabelecer os procedimentos necessários para trabalharem juntos no caso de um surto suspeito ou abrangente de doenças infecciosas » (ONU, 2004, p.17) 
Do ponto de vista da negociação do RSI, em que cerca de 190 países buscavam alcançar o consenso para adoção de um documento final, a possibilidade de atuação do Conselho de Segurança no campo da saúde pública foi vista como problemática pelos Estados e alimentou ainda mais a oposição em relação ao artigo 45 (WHELAN, 2008 p. 13), uma vez que o relatório abordava explicitamente o RSI como um possível instrumento a ser empregado no campo da segurança internacional.

O segundo ciclo de negociações do GIT ocorre em fevereiro de 2005, após a divulgação do relatório do Secretário da ONU, e terá como texto base para as negociações a versão do RSI elaborada pela Presidente do grupo de trabalho, juntamente com os representantes da OMS mais envolvidos na revisão, divulgada em 24 de janeiro de 2005 (OMS, 2005a).

$\mathrm{Na}$ versão apresentada por Whelan, são assinalados entre parênteses os artigos em que o consenso não havia sido ainda alcançado, marcando a necessidade de maiores discussões. Dessa forma, os termos « risco de saúde pública » ${ }^{66}$, ausente na versão de setembro de 2004 e « ameaça de saúde pública » aparecem entre parênteses, bem como o conceito de « doença », cuja definição não difere daquela apresentada na versão de setembro ${ }^{67}$, conforme apontado no quadro comparativo. $\mathrm{O}$ polêmico artigo 45 permanece e não sofre alteração, com o mesmo conteúdo apresentado na versão de setembro de 2004, porém também assinalado entre parênteses. $\mathrm{O}$ anexo 2, que define o algoritmo para as notificações, em nada foi alterado, ficando pendentes, contudo, as recomendações do grupo de analistas ad hoc, cujo relatório foi apresentado em fevereiro. A versão de janeiro de 2005 apresenta, portanto, poucas mudanças, sendo os dispositivos já identificados como os mais controversos os que ainda demandavam maiores discussões.

Antes da segunda rodada de negociações do GIT, ocorrem consultas regionais e sub-regionais, as quais ajudaram a clarificar posições e ilustrar os posicionamentos das delegações, sobretudo em relação aos dispositivos mais problemáticos da negociação. Dentre os documentos referentes a essas consultas, foram encontrados apenas o Consenso de Montevidéu, o relatório da terceira consulta regional do escritório da OMS para o Sudeste Asiático - ambos de janeiro de 2005 - e a Ata de Buenos Aires, de abril de 2005.

O Consenso de Montevidéu é o documento resultante do Seminario de Revisión del Reglamento Sanitario Internacional, realizado entre os dias 26 a 28 de janeiro, envolvendo os

\footnotetext{
${ }^{66} \mathrm{O}$ termo risco de saúde pública é reintroduzido com a definição « an event posing a probability of international spread of disease » (OMS, 2005a).

${ }^{67} \mathrm{Na}$ versão apresentada em janeiro de 2005, doença « significa uma doença animal ou humana que apresenta um risco de dano significativo aos humanos, causados por fontes biológicas, química ou radio-nuclear »
} 
países do Mercosul e da Comunidade Andina, com o propósito de discutir a versão do RSI apresentada pela Presidente do GIT, a fim de consolidar uma posição comum da região para a etapa final de negociação, propondo alternativas de redação para os temas ainda pendentes de discussão. Esse documento embasou o posicionamento conjunto dos países latino-americanos nas negociações de fevereiro e, segundo Whelan, facilitou o progresso em várias áreas (2008, p. 13).

Ao analisar o documento Consenso de Montevidéu, fica clara a posição contrária dos Estados quanto à inclusão do termo " ameaça » no Regulamento, sugerindo que este deveria ser substituído por « risco », especialmente na definição de ESPII e no propósito do RSI. Os países apoiam a definição de « risco de saúde pública », por esse conceito ser mais amplo e mais adequado aos objetivos de saúde pública, do que o termo « ameaça de saúde pública », terminologia não usual para saúde pública (CONSENSO DE MONTEVIDÉU, 2005).

Em relação ao controverso artigo 45, os países propõem a sua supressão completa, defendendo que não há argumentos que justifiquem sua inclusão, uma vez que esse dispositivo não exige que um evento de caráter intencional esteja relacionado à situação de risco de saúde pública e essa linguagem ampla excede o âmbito de aplicação do RSI (CONSENSO DE MONTEVIDÉU, 2015, p. 13). As posições dos países latino-americanos, apresentadas no Consenso de Montevidéu são reafirmadas mais tarde na Ata de Buenos Aires ${ }^{68}$, em abril (ATA DE BUENOS AIRES, 2005). Essas consultas regionais, no momento final da revisão, favoreceram o avanço das negociações ao consolidar a posição de um grupo de países, e as propostas de modificação sugeridas pelos latinoamericanos influenciaram a redação do texto final do Regulamento (ENTREVISTADO 1, 2014).

Na segunda reunião do grupo de trabalho, iniciada em 21 de fevereiro, modificaram-se os métodos de negociação: quando temas de difícil consenso eram levantados, abriam-se grupos de trabalho para buscar uma solução, o que demonstrou ser muito efetivo (WHELAN, 2008, p. 13). Na noite de 26 de fevereiro, as negociações chegam novamente a um impasse, sendo as reuniões adiadas para 13 de maio de 2005 (WEIR, 2015, p.25).

Nessa etapa final de negociação, cresce o grupo de oposição à inclusão de elementos de segurança na versão do RSI, identificados, sobretudo, no artigo 45 e na menção explícita a agentes químicos e radio-nucleares em alguns dispositivos. Os países da SEARO, que, até as negociações de novembro, tinham posições divididas em relação às temáticas de segurança, os Estados do EMRO, que, até então, não tinha se pronunciado oficialmente sobre essas questões, juntamente com

\footnotetext{
${ }^{68}$ Documento resultante do « Seminário de Revisão do Regulamento Sanitário Internacional dos países da área Andina e do Mercosul » nos dias 25 a 27 de abril de 2005, com vistas a analisar o texto de revisão e as propostas de modificação sugeridas na segunda rodada de negociação do grupo intergovernamental de trabalho.
} 
alguns membros do WPRO, posicionam-se contra a inclusão de tais temas no RSI (WEIR, 2015, p. 25).

Forma-se, assim, o « bloco do Sul », que inclui países do EMRO, SEARO, alguns membros do WPRO e os países da da América do Sul, participantes de Declaração de Montevidéu (WEIR, 2015, p.25). O bloco do Sul concorda com a abordagem all risks do RSI, porém defende a supressão do artigo 45 e de qualquer menção aos agentes químicos, biológicos ou radio-nucleares do texto no Regulamento. Não foi possível confirmar, contudo, se os signatários da Declaração de Montevidéu agiram em coordenação com EMRO, SEARO ${ }^{69}$ e membros do WPRO. Segundo apontado por Weir (2015, p. 25), ao menos um país do Norte estava aliado ao posicionamento do bloco do Sul: o Japão.

No dia 24 de fevereiro foi apresentado um documento mencionando os progressos até então realizados nesse segundo ciclo de negociações. Chega-se à definição final para doença, retirando-se a menção a agentes biológicos, químicos e radio-nucleares e inserindo « independentemente de sua origem ou fonte »; a expressão " ameaça de saúde pública » é suprimida, mantendo-se o termo « risco de saúde pública », cuja definição ainda não é consensual. O conteúdo de artigos essenciais do RSI, como o artigo 2, referente ao propósito e ao escopo; artigo 4 sobre vigilância, que repercutia sobre questões de soberania; artigo 5 sobre notificações; e o artigo 45 não era ainda consensual, o que demandava mais negociação (OMS, 2005c).

As negociações finais ocorreram nos dias 12 e 13 de maio, e os principais temas discutidos foram divididos em três grupos: o primeiro grupo para tratar de surtos de doenças de origem não natural; o segundo para medidas adicionais de saúde e o terceiro grupo para artigos finais para o RSI entrar em vigor e reservas (WHELAN, 2008, p. 15). Chega-se a um acordo final nas primeiras horas do dia 14 de maio e, no dia 23, a Assembleia Mundial da Saúde adota o RSI por unanimidade.

Como resultado de uma década de negociações, na versão final do Regulamento adotado, está ausente o termo « ameaça à saúde pública » e, nos artigos em que esta expressão estava presente, ela foi substituída por « risco para a saúde pública », termo definido como « a probabilidade de um evento que possa afetar adversamente a saúde de populações humanas, com ênfase naqueles que possam se propagar internacionalmente, ou possam apresentar um perigo grave e direto» (ANVISA, 2009, p. 17), o que difere substancialmente das definições apresentadas nas versões ante-

\footnotetext{
${ }^{69}$ As entrevistas realizadas por Kelle (2007) com os participantes da reunião de maio de 2005 mostraram que grupos regionais do EMRO e SEARO foram liderados pelos delegados do Paquistão e Irã contra a inclusão do artigo 45. Kelle realizou entrevistas com membros das delegações que participaram das negociações do RSI em maio de 2005 . As entrevistas foram realizadas em dezembro de 2005 e os resultados são relatados no artigo « Securitization of International Public Health: Implication for Global Health Governance and the Biological Weapons Prohibition Regime » de 2007.
} 
riores. Destaca-se que o posicionamento dos países do bloco Sul foi decisivo para que na versão final do Regulamento não constasse nenhum artigo que vinculasse explicitamente o RSI a casos de uso intencional de agentes infecciosos ou tóxicos e para que não houvesse qualquer menção à fontes biológicas, químicas e radio-nucleares (WEIR, 2015, p25). Dessa forma, o polêmico artigo 45 foi suprimido e a definição de doenças ganha uma nova redação sem qualquer referência explícita a tais agentes.

Todavia, a solução encontrada para permitir, implicitamente, que o RSI possa ser aplicado a casos de doenças relacionados ao uso intencional de agentes infecciosos ou tóxicos, sem inserir um dispositivo explícito para esses casos, foi a adoção de um conceito amplo e aberto para doenças, combinado ao artigo 7 do Regulamento. Definir doença como « doença ou agravo, independentemente de origem ou fonte, que represente ou possa representar um dano significativo para os seres humanos » (ANVISA, 2009, p.14) e determinar que « caso um Estado Parte tiver evidências de um evento de saúde pública inesperado ou incomum dentro do seu território, independentemente de sua origem ou fonte, que possa constituir uma emergência de saúde pública de importância internacional, ele fornecerá todas as informações de saúde pública relevante à OMS » (Ibid., p.21), significa permitir a aplicação do RSI a eventos cuja origem possa ser um incidente ou ato intencional envolvendo agentes biológicos, químicos ou radio-nucleares.

Em declaração apresentada em 23 de maio de 2005, os Estados Unidos reafirmam esse entendimento implícito de que os Estados Partes, sob o novo Regulamento, estão obrigados a notificar eventos que envolvam usos acidentais ou deliberados de materiais biológicos, químicos e radiológicos que possam constituir uma ESPII, visto que o uso intencional ou acidental de tais agentes certamente constituirá um evento « inesperado ou incomum », « independentemente da fonte ou origem ». Os EUA apontam ainda que a OMS já tinha reconhecido explicitamente seu papel nesse âmbito com a resolução 55.16, afirmando, portanto, que irão utilizar o RSI com entendimento de que este se aplica a todas ameaças à saúde, a todas as suas causas e tipos de eventos, independentemente se estes ocorrem de modo natural, acidental ou deliberado, esperando que todos os Estados membros da OMS façam o mesmo (EUA, 2005, p. 2).

Essa declaração dos EUA evidencia, mais uma vez, os interesses que estavam em jogo ao longo das negociações, pois fica claro que parte dos negociadores queria que o RSI cobrisse todas as possíveis ESPII, inclusive as resultantes de terrorismo não convencional, buscando, ao mesmo tempo, insular a OMS de temas politicamente sensíveis tradicionalmente cobertos pelos tratados de controle de armas e pelo CS da ONU. Quando questionado se o RSI teria sido negociado como um 
documento de segurança, o membro da delegação brasileira afirmou que se tentou negociá-lo como documento de segurança nas negociações dos grupos de trabalho e na Assembleia, mas o posicionamento dos países da América do Sul e blocos aliados levou o Regulamento para o campo saúde pública (ENTREVISTADO 1, 2014).

A fim de evitar um conflito entre a OMS e outros organismos internacionais, sobretudo quando uma epidemia envolver agentes, químicos ou radio-nucleares, foi incluído no artigo 6, referente a notificação, que, caso uma notificação recebida envolva a competência da AIEA, a OMS notificará imediatamente essa Agência. Além disso, está previsto no artigo 14 que a OMS deverá cooperar e se coordenar com outras organizações internacionais no caso de notificação, verificação ou resposta a eventos que recaiam em sua matéria de competência (ANVISA, 2009, p. 25).

A natureza do documento final reflete, portanto, um equilíbrio entre os interesses dos atores que buscavam ampliar o mandato do RSI como um instrumento de segurança e os países que não desejavam que as normas sanitárias extrapolassem sua missão em saúde pública (TUCKER, 2005, p.343). Esse compromisso produziu um Regulamento, que, apesar de explicitamente não estar vinculado a elementos de segurança introduz um mecanismo « dual » que tem a possibilidade de ser ativado em situações em que os objetivos em jogo não se restrigem à saúde pública.

\subsection{O novo RSI: um documento de segurança?}

A adoção do novo RSI representou um mudança radical tanto para o controle internacional de doenças infecciosas quanto para a governança em saúde pública. O RSI rompe com denominado « regime clássico » de saúde pública internacional (Fidler, 2005, p. 328), introduzindo uma nova lógica no combate à propagação de doenças, combinando objetivos de saúde pública com a estratégia de segurança sanitária mundial.

Desde a primeira Conferência Sanitária Internacional, em 1851, a cooperação internacional para o controle de doenças era marcada pela existência de vários tratados internacionais que se sobrepunham e submetiam um limitado número de países, um verdadeiro «patchwork of treaties on infectious disease » (Ibid., p. 329). A partir da criação da OMS, em 1946, os regulamentos 
sanitários internacionais ${ }^{70}$ adotados pela organização tornaram-se os principais instrumentos contra a propagação de doenças infecciosas no âmbito internacional.

Ao comparar o atual RSI com suas versões anteriores, constata-se uma mudança drástica nos métodos e procedimentos aplicados. Enquanto os dois primeiros regulamentos aplicavam-se somente a uma lista específica e restrita de doenças ${ }^{71}$, dependiam inteiramente da notificação dos Estados e concentravam-se na utilização de medidas nas fronteira para combater a transmissão internacional de doenças, o atual RSI introduz novos conceitos e categorias que redimensionam o controle internacional de doenças, estabelecendo uma vigilância global de emergências (WEIR, 2010), cujo foco não mais é a aplicação de medidas nas fronteiras, mas a contenção dos riscos de saúde pública em sua origem.

Os conceitos reproduzidos no quadro comparativo ${ }^{72}$ consubstanciam a expansão do escopo do RSI, devendo cada Estado notificar a OMS « sobre todos os eventos em seu território que possam constituir uma emergência de saúde pública de importância internacional, segundo o instrumento de decisão " (artigo 6). O novo RSI cria, assim, um escopo "dynamic, flexible, and forward-looking" (FIDLER; 2005, p.362), estabelecendo uma abordagem que cobre todos os riscos possíveis, independentemente da fonte ou origem, uma "all-risks approach" (FIDLER; GOSTIN, 2006; p.3).

Destaca-se que a criação do conceito de ESPII como uma categoria aberta, que não se encerra em doenças infecciosas, englobando doenças existentes, emergentes e potenciais e a formulação do algoritmo para auxiliar os Estados na avaliação e notificação dos eventos que podem constituir uma ESPII (Anexo 2) são os mecanismos trazidos pelo RSI para determinar se um evento pode ser considerado uma ameaça à saúde pública. Caso o evento notificado seja declarado uma ESPII, criase um espaço político permissível à adoção de medidas emergenciais pela OMS, as quais tendem a ser facilmente aceitas pela audiência, no caso os Estados membros, podendo ser legitimadas por um discurso de segurança. Uma ESPII não é definida no RSI como ameaça à segurança; tal conceito, contudo, não está longe de identificar eventos de doenças perigosos como problemas de segurança (FIDLER, 2007; p.52).

\footnotetext{
70 Desde sua criação, a OMS adotou três regulamentos, um em 1951, em 1969 - que sofre uma atualização em 1981 com a erradicação da varíola - e o mais recente em 2005.

${ }^{71} \mathrm{O}$ regulamento de 1951 aplicava-se a seis doenças - cólera, peste, febre amarela, varíola, tifo e febre recorrente - e o de 1969, inicialmente, a quatro - cólera, peste, febre amarela e varíola. Com a erradicação da varíola o RSI de 1969 passa a ser aplicado somente às três doenças restantes.

72 Ver página 50.
} 
O RSI confere prerrogativas à OMS que reforçam sua autoridade e autonomia no âmbito do regime de controle internacional de doenças. Cabe ao Diretor Geral da organização decidir o início e o fim de uma emergência de saúde pública de importância internacional (artigo 12), podendo utilizar, para isso, informações de outras fontes, para além das consultas e notificações estatais (artigo 9). Dessa forma, o Diretor Geral pode declarar uma ESPII independentemente da notificação e do consentimento do Estado afetado, apoiando-se na opinião de um Comitê de Emergência, cujos membros são recrutados de modo autônomo pela organização (artigo 48). A OMS, portanto, adquire maior autonomia e capacidade de ação em casos de surtos de doenças, subtraindo, nas situações em que não há notificação pelos Estados atingidos, a vigilância epidemiológica internacional do controle dos Estados.

O atual Regulamento produz, assim, um « direito da emergência, de natureza transversal, como intersecção entre o direito internacional e o direito interno » (VENTURA, 2013, p. 38). As normas sanitárias introduzidas pelo RSI configuram um mecanismo complexo que permite à OMS tomar medidas independentemente da vontade dos Estados e mesmo em caso de omissão destes. As implicações desse direito da emergência são diversas, sobretudo quando consideramos que o RSI institui um regime jurídico que pode justificar restrições significativas aos direitos e liberdades e que o Regulamento tem aplicabilidade imediata, tendo em vista sua adoção sob mecanismo de opting out, o que possibilita «invocá-lo em juízo, independentemente de sua internalização » (Ibid, p. 157$)^{73}$.

O foco do RSI não são doenças graves, de alta letalidade, ou a construção de infraestrutura básica com vistas à prevenção de novos riscos de saúde, mas sim medidas de vigilância e de resposta a emergências, voltadas a conter, em sua fonte, doenças de potencial alcance internacional e que demandam cooperação para serem enfrentadas. Nesse sentido, o Regulamento determina que os Estados devem desenvolver, fortalecer e manter capacidades básicas de saúde pública em nível local, regional e nacional para detectar, avaliar e notificar eventos de doenças e responder de forma efetiva aos riscos e emergências de saúde pública (artigo 5). Essas capacidades básicas são detalhadas no Anexo 1 do Regulamento. O RSI busca instituir, assim, um mecanismo de vigilância sanitária flexível, aplicável até mesmo a riscos que ainda não emergiram. « Ser Parte do RSI

\footnotetext{
73 O mecanismo de opting out remete ao artigo 22 da Constituição da OMS que prevê que « os regulamentos adotados em conformidade com o artigo 21 entrarão em vigor para todos os Estados membros depois de a sua adoção ter sido devidamente notificada pela Assembléia da Saúde, exceto para os Estados membros que comuniquem ao Diretor Geral a sua rejeição ou reservas dentro do prazo indicado na notificação » (OMS, 1946). Dessa forma, de acordo com o artigo 59 do RSI, o prazo para a rejeição ou apresentação de reservas é de 18 meses a partir da data da notificação pelo Diretor Geral quanto à sua adoção. Isso significa que « se um Estado ficar em silêncio durante este prazo, ele é inexoravelmente vinculado ao Regulamento » (VENTURA, 2013, p. 158)
} 
implica, então, estar vinculado a um direito da emergência sanitária, mas igualmente dotar-se de condições objetivas para sua aplicação, que deve ser aferível e pode ser controlada por um organismo internacional» (Ibid., p. 163).

A criação da categoria ESPII e a autoridade conferida ao Diretor Geral para a ativação desse dispositivo produz um cenário receptivo a discursos de segurança, que, aliado ao capital social da OMS em governança global e ao fato de que problemas de saúde são naturalmente vistos como ameaças, criam as condições necessárias para atos de securitização de emergências de saúde pública. Ademais, com base nos conceitos de doença, de ESPII e no algoritmo desenvolvido para operacionalizar essa categoria, o RSI se insere no conjunto de mecanismos internacionais que lidam com ameaças de armas de destruição em massa, conectando, num mesmo instrumento, doenças infecciosas e armas químicas e biológicas. Nesse sentido, o RSI é um exemplo notável da mudança no pensamento não apenas da governança de armas biológicas, mas também no relacionamento entre segurança e saúde pública (FIDLER; GOSTIN, 2007, p.138).

A linguagem de segurança global facilita o surgimento de organizações internacionais enquanto atores cujas decisões moldam como ameaças emergentes são governadas. Se apresentar um problema como ameaça à segurança nacional amplia a margem de discricionariedade do poder executivo no plano estatal, a securitização de riscos transfronteiriços pode fortalecer a autoridade supranacional das organizações internacionais (HANRIEDER; SONNEN, 2014, p. 2).

Em casos de crise de segurança global, situações que demandam decisões rápidas e centralizadas, tende a haver um empoderamento das organizações internacionais, que consiste, principalmente, em autoridade política decisória para determinar a existência de uma situação de emergência e definir as medidas necessárias para enfrentar a ameaça. Assim, as decisões de uma organização internacional determinam a agenda para o comportamento estatal em tempos de crise, bem como em futuras securitizações (Ibid, p. 4). No caso da saúde global, o RSI é o instrumento de governança que empodera a OMS e fundamenta sua autoridade em caso de emergências sanitárias, conferindo-lhe a possibilidade de tomar decisões, independentemente do consentimento dos Estados. Apesar de a organização ter somente prerrogativas de emitir recomendações, consideradas como soft law ${ }^{74}$, uma vez que carecem de caráter coercitivo, estas tendem a ser adotadas pelos Estados frente ao constrangimento político que sofreriam caso não as implementassem.

\footnotetext{
${ }^{74}$ Nasser (2005, apud PORTELA, 2010, p.75) define soft law como um conjunto de « regras cujo valor normativo seria limitado, seja porque os instrumentos que as contêm não seriam juridicamente obrigatórios, seja porque as disposições em causa, ainda que figurando em um instrumento constringente, não criariam obrigações de direito positivo ou não criariam senão obrigações pouco constringentes ».
} 
Parte da literatura aponta o importante papel desempenhado pelo Secretariado no processo de revisão do RSI, considerando o paradigma de segurança sanitária mundial promovido pela OMS durante as negociações e o fato de que organizações internacionais não são atores passivos, mas formadores de normas, podendo seus secretariados alterar o mundo com a introdução de novas regras (KAMRADT-SCOTT, 2010). De acordo com Davies, Kamradt-Scott e Rushton, o poder conferido à OMS sobre o processo de revisão do RSI proporcionou ao Secretariado uma oportunidade valiosa para se engajar na formulação de normas e promover seu regime ideal de segurança sanitária global (2015, p.27).

O conceito de segurança sanitária mundial reivindica a proteção das coletividades contra riscos globais que afetam a saúde coletiva das populações (OMS, 2007). Essa definição abarca dimensões tanto de segurança humana quanto de segurança nacional, uma vez que proteger as populações é uma forma de garantir também a segurança do Estado. No entanto, na forma como o RSI busca operacionalizar a segurança sanitária, o Estado se sobressai, em última instância, como objeto referente de segurança. Nessa perspectiva, Rushton afirma que « tanto o RSI quanto o conceito de segurança sanitária mundial, que tem sido estreitamente vinculado ao Regulamento, permanecem, em termos de segurança, persistentemente estadocêntricos: o objeto referente permanece sendo o Estado. Essa é uma visão de saúde global muito mais estatista que globalista $»^{75}$ (2011, 789, tradução nossa).

Apresentar uma questão de saúde como problema de segurança traz um capital simbólico importante que favorece a mobilização política e de recursos, bem como a priorização do tema. Contudo, utilizar a mentalidade de segurança para abordar problemas de saúde pública, como respostas a surtos de doenças infecciosas, não necessariamente conduz ao maior nível de cooperação. Estruturar as negociações em saúde pública com base nos interesses de segurança nacional complexifica o ambiente político inserindo as negociações numa ampla rede de disputas políticas, o que pode gerar efeitos colaterais não desejáveis ${ }^{76}$ (ELBE, 2010, p. 484).

Ao responder crises sanitárias aplicando-se discurso e medidas de segurança, caracterizando uma doença como ameaça, instaura-se um pânico e histeria coletiva que ativam uma lógica de

\footnotetext{
75 Traduzido do inglês: « Both the IHR and the concept of global health security that has been so closely linked with it remain, in security terms, stubbornly state-centric: the referent object remains the state. This is very much a statist rather than a globalist vision of global health »

76 Elbe faz referência, nesse artigo, especificamente à controvérsia em relação ao compartilhamento de amostras do vírus H5N1, desencadeada pela decisão da Indonésia em se recusar a compartilhar as amostras do vírus em dezembro de 2006. Segundo o autor, a securitização do vírus H5N1 contribuiu para a prolongada disputa em torno do compartilhamento das amostras do vírus entre países desenvolvidos e os em desenvolvimento.
} 
guerra, inserindo a questão num binômio ameaça-defesa. Esse cenário pode levar à estigmatização dos infectados, bem como à criação de um ambiente permissivo à utilização de crises sanitárias como justificativa para restringir direitos e liberdades dos indivíduos, sem qualquer benefício à saúde pública. Ademais:

confinar a resposta às emergências internacionais de saúde ao prisma de segurança condenaria a saúde global a uma sucessão infinita de período de 'guerra' e 'trégua' focadas nos sistemas de vigilância e não no enfrentamento as causas das epidemias, vinculadas aos determinantes sociais da saúde (VENTURA, 2016, p. 3).

Apesar da centralidade do RSI para a segurança sanitária mundial e para a governança global em saúde, sua implementação, principalmente no que se refere às capacidades básicas para vigilância e respostas, previstas no Anexo 1 do Regulamento, ainda é muito precária entre os Estados Partes. Em novembro de 2014, apenas 64 Estados indicaram ter implementado o nível mínimo para tais capacidades, 81 pediram a extensão adicional de 2 anos para implementá-las e 48 Estados não informaram sua situação à OMS (OMS, 2015, p. 4) $)^{77}$. Essa situação denota que, não obstante seu viés securitário, o RSI, desde sua entrada em vigor, em junho de 2007, até 2014, quando tem início o surto de Ebola na África Ocidental, não figurou como prioridade nas agendas políticas na maior parte dos países.

A recente epidemia do Ebola, considerada uma emergência de saúde pública de importância internacional de agosto de 2014 a março de 2016 (OMS, 2016c), além de expor a falta de comprometimento dos Estados Partes com a implementação do RSI, levou a comunidade internacional a reavaliar suas prioridades globais e apreciar a importância do Regulamento como um instrumento multilateral capaz de guiar países e organizações internacionais na preparação para o enfrentamento de emergências sanitárias (OMS, 2016, p.7). A crise do Ebola, portanto, renovou o interesse da comunidade internacional no RSI, desencadeando várias iniciativas, especialmente no âmbito da OMS, com o intuito de avaliar as fragilidades na implementação do Regulamento e apoiar o desenvolvimento e fortalecimento das capacidades básicas em saúde pública (OMS, 2015b; OMS,

\footnotetext{
77 O sistema de monitoramento da implementação das capacidades básicas em saúde pública usa um questionário de autoavaliação enviado aos Estados Partes desde 2010 para notificar a AMS sobre o status de desenvolvimento das capacidades básicas em saúde publica exigidas pelo RSI (OMS, 2016, p.4). Em 2016, 127 dos 196 Estados Partes completou o questionário de auto-avaliação sobre a implementação do RSI enviado em 2015 e os resultados podem ser consultados na página da OMS: http://www.who.int/ihr/procedures/monitoring/en/ (acessados em Julho 2016)
} 
2016b) ${ }^{78}$. Há, portanto, na atual conjuntura, um esforço em resgatar a centralidade do RSI como principal instrumento da segurança sanitária mundial, sustentando-o como prioridade política nas agendas globais.

\section{CONCLUSÃO}

A construção política de doenças infecciosas como ameaças à segurança, seja do Estado, do indivíduo ou de coletividades, contribuiu para a expansão das agendas de segurança e tornou o nexo saúde-segurança um aspecto fundamental no debate acadêmico e na formulação de políticas. A interface entre saúde e segurança tem recebido considerável atenção acadêmica, sendo a teoria da securitização da Escola de Copenhague uma ferramenta analítica frequentemente utilizada para compreender o processo por meio do qual temas de saúde são securitizados.

$\mathrm{O}$ atual RSI foi negociado em um contexto marcado pela crescente securitização de doenças infecciosas, fenômeno que redimensionou o papel da saúde pública, sobretudo dos sistemas de vigilância e resposta, inserindo-os numa lógica de defesa e segurança. Esta pesquisa demonstrou que o processo de revisão do RSI não esteve imune a esse contexto e que a OMS desempenhou papel fundamental ao longo das negociações, servindo tanto como espaço discursivo, no qual a securitização da saúde pública era debatida, quanto como ator securitizador em seu próprio termo, promovendo o seu paradigma de segurança sanitária mundial (KELLE, 2007, p.230).

Os atentados terroristas do 11 de setembro, seguidos dos ataques de antraz, ao reforçar a tendência securitizadora da saúde pública, sob o enfoque de biossegurança e bioterrorismo, criaram um ambiente político fértil para que esse novo paradigma avance e apresente o RSI como seu principal instrumento. O resultado é a adoção do novo RSI como o fundamento normativo que legitima a segurança sanitária mundial como estratégia de governança em saúde, introduzindo uma com-

\footnotetext{
78 Algumas dessas iniciativas foram a criação de um Painel de analistas independentes externo, com base na resolução do Conselho Executivo EBSS3.R1 de janeiro de 2015, para realizar uma avaliação provisória sobre todos os aspectos da resposta da OMS ao surto de Ebola, o que resultou no Report of the Ebola Interim Assessment Panel, divulgado em julho de 2015 (OMS, 2015b); e a criação do Comitê de Revisão sobre o papel do RSI na Resposta ao Surto de Ebola (The Review Committee on the Role of the International Health Regulations (2005) in the Ebola Outbreak and Response), em maio de 2005, resultou no Report of the Review Committee on the Role of the International Health Regulations (2005) in the Ebola Outbreak and Response (OMS, 2016b). Destacamos ainda outras comissões para avaliar a resposta à epidemia do Ebola à luz do RSI: Independent's Panel on the Global Response to Ebola iniciativa conjunta da Universidade de Havard e London School of Hygiene \& Tropical Medicine; Commission on a Global Health Risk Framework for the Future formada pela Academia Nacional de Medicina dos Estados Unidos; o High-Level Panel on the Global Response to Health Crises das Nações Unidas
} 
plexa engrenagem que pode ser aplicada para além de casos de epidemias, cuja pedra angular é a criação da categoria emergência de saúde pública de importância internacional.

Nesse sentido, a securitização da resposta internacional à crise do Ebola é consistente com uma prática já consolidada de securitização da saúde pública. Apesar de a resolução 2177 do CS e a criação da MINAUCE vincularem explicitamente a implementação do RSI a um discurso e estratégia de segurança, a aplicação do Regulamento, desde sua entrada em vigor, não havia ganho os holofotes das políticas de segurança, considerando o seu baixo grau de implementação nos Estados Partes. A epidemia do Ebola expôs as inadequações e fragilidades das instituições nacionais e internacionais para enfrentar uma crise sanitária, dentre elas o frágil comprometimento dos Estados com o RSI, bem como os desafios para atingir o nível mínimo de capacidades básicas em vigilância e resposta exigidas.

Embora a perspectiva securitária tenha desempenhado um papel fundamental no processo de negociação do atual RSI, a sua implementação, aparentemente, não foi enquadrada como questão de segurança nos Estados, o que possivelmente teria mobilizado recursos e vontade política para a efetiva aplicação desse instrumento. A recente epidemia do Ebola, todavia, ao mostrar na prática os efeitos nefastos de uma crise sanitária, lança um novo olhar sobre a relevância do Regulamento, desencadeando uma agenda de reformas no âmbito da OMS e reavivando o interesse dos Estados na segurança sanitária mundial. Se esse cenário impulsionará, de fato, a implementação do RSI ainda é incerto, mas dentre os questionamentos que ele nos traz, um nos parece central: é necessário que a implementação do RSI seja enquadrada como uma questão de segurança para que suas normas sanitárias ganhem efetividade e saúde global seja uma prioridade política? 


\section{ANEXO I - Lista de entrevistados}

No âmbito desta pesquisa, foram realizadas quatro entrevistas com membros de delegações de quatro países diferentes que estavam envolvidos no processo de revisão do RSI, sobretudo na fase final, a partir de 2004. A escolha dos entrevistados se deu a partir da disponibilidade e vontade dos mesmos, bem como da possibilidade de realização da entrevista. Ao menos 15 membros de delegações de países diversos foram contactados, contudo, nem todos responderam ao contato inicial do pesquisador ou estavam dispostos a conceder entrevista. O estágio realizado no Observatoire Politique de l'Amérique Latine et Caraïbes (OPALC), vinculado à Sciences Po Paris, no primeiro semestre de 2015 e o estágio no escritório da OMS em Lyon, vinculado ao Department of Global Capacities, Alert and Response, no segundo semestre de 2015, foram essenciais para viabilizar algumas das entrevistas, ao facilitar o contato com os possíveis entrevistados.

A metodologia utilizada foi entrevista semipadronizada com perguntas abertas (BERNARD, 1974, p165). Duas entrevistas foram realizadas pessoalmente e duas via e-mail. A lista dos entrevistados e os questionários utilizados na condução das entrevistas encontram-se abaixo.

\section{Lista de entrevistados}

Entrevistado 1 - Membro da delegação brasileira negociadora do RSI (entrevistado em outubro de 2014)

Entrevistado 2 - Membro da delegação francesa negociadora do RSI (entrevistado em abril e 2015)

Entrevistado 3 - Membro da delegação irlandesa negociadora do RSI (forneceu artigo sobre as negociações em abril 2015)

Entrevistado 4 - Membro da delegação da Nova Zelândia negociadora do RSI (entrevistado em março 2016) 


\section{ANEXO II - Questionários utilizados para a realização das entrevistas}

\section{ROTEIRO 1 - Português}

1. Você foi integrante da delegação brasileira que negociou o novo RSI? Em qual período?

2. Qual é o seu atual cargo na Organização Mundial da Saúde?

3. Quem eram os demais integrantes da delegação brasileira?

4. Qual foi a metodologia da negociação?

5. Quais dos ciclos de negociações foi o mais polarizado ou polemizado? Por que na reunião de novembro de 2004 não conseguiu chegar a um consenso sobre o documento final?

6. Na sua opinião, o RSI foi negociado desde o começo como um documento de segurança?

7. Quais foram os Estados que mais se destacaram durante as negociações? Houve algum Estado que monopolizou, em algum momento, a negociação?

8. Quais foram os dispositivos que causaram mais polêmica durante a negociação? Houve polarização em relação a quais temas?

9. Várias vezes o prazo para a conclusão do RSI foi adiado, na sua opinião, quais foram as razões principais para o atraso nas negociações?

10.Na sua opinião, os ataques do 11 de setembro e os subsequentes ataques de anthrax influenciaram o processo de negociação?

11.Houve uma preocupação clara, ao longo das negociações, com biossegurança e bioterrorismo?

12.Qual dos dois eventos tiveram maior impacto para o destravamento das negociações: os ataques do 11 de setembro e anthrax ou a epidemia de SARS 2003?

13.O relatório do Secretário Geral da ONU High Level Panel on Threats Challenges and Changes de dezembro de 2004 teve algum impacto nas negociações?

14.A expansão do escopo do RSI, ampliando a base para notificações, incorporando doenças de origem ou fonte diversas, foi proposto logo na primeira versão provisória de janeiro de 1998 . Essa alteração drástica do escopo do RSI foi consensual?

15.Como foi a negociação do conceito "emergência de saúde pública de importância internacional", bem como o anexo II que estabelece o algoritmo que os Estados devem usar para notificarem determinado evento de doença a OMS? 
16. Como foi negociada a prerrogativa do Diretor Geral da OMS para declarar uma emergência pública de importância internacional e utilizando, para isso, fontes de informação não-governamentais? Foi um ponto polêmico a autoridade do Diretor Geral para declarar inicio e fim de uma ESPII?

17.Qual foi o posicionamento do Brasil durante as negociações? Quais temas foram os mais debatidos pelo Brasil?

18.O RSI foi recebido pela delegação brasileira como um documento de segurança?

19.O RSI tem sido aplicado como documento de segurança?

20.Quais são as fragilidades na implementação do RSI no ordenamento brasileiro, na sua opinião?

\section{ROTEIRO 2 - Inglês}

1. Did you participate in the negotiations of the International Health Regulations? When?

2. In your point of view, why were the negotiations so lengthy and difficult? What were the main reasons for delaying the negotiations?

3. Were the negotiations stalled before 2003?

4. There were three round of negotiations (November 2004, February 2005 and May 2005), which one of these was the most controversial and contentious?

5. In your opinion, were the International Health Regulations negotiated as a security document?

6. Do you believe that security issues, such as bioterrorism, chemical and biological weapons influenced the negotiations? Were security issues decisive to reach a consensus about the new IHR?

7. In your opinion, did the 11 September and anthrax attacks influenced in some manner the negotiations?

8. Which of these events had a major impact on the negotiations process:the11 September and anthrax attacks in 2001 or the SARS epidemic in 2003 ?

9. Did the Secretary-General's High-level Panel Report on Threats, Challenges and Change, released in December 2004, have any impact on the negotiations? Why? 
10. Which states stand out in the negotiations? Which ones played an important role in the negotiations?

11. Can you point out what were the most controversial and difficult issues to reach a consensus in the negotiations of February 2005?

12. The broad scope of the IHR was an outstanding issue. What were the main questions raised about the IHR being applied to naturally and non-naturally occurring outbreaks of disease?

13. Did states consider that the IHR should play an important role in security matters?

14. Do you consider the new term "public health emergency of international concern" a progress regarding public health surveillance and response?

15. How was the negotiation of this new term as well as the annex II?

16. According to the new IHR, the Director-General determines, on the base of information received, whether an event constitute a public health emergency of international concern (article 12). Was this a controversial issue or states were in agreement that the Director-General should have this prerogative?

17. The new IHR allow the WHO to take into account reports from sources other than notifications and consultations to declare a public health emergency of international concern. Was this a contentious issue during the negotiations?

18. Which states were supporting the controversial article 41 (the IHR draft of January 2004) and then article 45 (the IHR draft of September 2004) about the information sharing during a suspected intentional release of chemical, biological or radionuclear agent? Why was this article dropped from the final version? 


\section{ROTEIRO 3 - Francês}

1. Vous étiez membre de la délégation française qui a participé aux négociations du RSI en 2005. Pourriez-vous préciser la période des négociations auxquelles vous avez participé, s'il vous plaît? Après la formation du groupe de travail intergouvernemental il y a eu trois cycles de négociations: en novembre 2004, février 2005 et mai 2005. A quelles réunions avez vous participé ?

2. Est-ce que 1'Union Européenne a négocié en général comme un bloc ou chaque pays a-t-il pris sa position individuellement? Les États européens avaient-ils une position commune?

3. À votre avis quelles sont les raisons principales pour lesquelles les négociations du RSI ont duré si longtemps, 10 ans?

4. On voit qu'après 2003 les négociations ont avancé, peut-on dire qu'avant 2003 la négociation était de certaine manière bloquée?

5. D'entre ces trois réunions, laquelle a été la plus polémique ou la plus difficile à arriver à un consensus? Pourquoi croyez vous qu'on n'aie pas réussi à parvenir à un accord final après les négociations de novembre 2004 ?

6. À votre avis, le RSI a-t-il été négocié comme un document plutôt de sécurité sanitaire que de santé publique?

7. Croyez vous que des préoccupations de sécurité internationale, comme le bioterrorisme, les armes biologiques et chimiques aient vraiment influencé la révision? Pensez vous que ce type de préoccupations aie été décisif pour les négociations?

8. À votre avis, les attaques du 11 septembre et les attaques à l'anthrax en 2001 ont-elles influencé, d'une certaine manière les négociations? Croyez-vous que ces événements aient joué un rôle important pour l'avancement des négociations?

9. Pour faire avancer les négociations, quel événement a joué un rôle majeur: la crise de SARS en 2003 ou les attaques du 11 septembre et les préoccupations de sécurité sanitaire qu'elles ont entraîné?

10.Le rapport du Secrétaire Général de L'ONU: High Level Panel on Threats Challenges and Changes (Panel de haut niveau sur les menaces, les défis et les changements) de décembre 2004 a-t-il eu un impact sur les négociations? Pourquoi?

11.Au cours des négociations, est-ce qu'un État a joué un rôle proéminent dans la négociation sur certains sujets? Y a-t-il eu un État en particulier qui a monopolisé les discussions par rapport à un article ou un sujet?

12.En général, les États ont-ils considéré que le RSI devrait jouer un rôle déterminant dans le champ de la sécurité internationale? Quelle a été la position de la France? 
13.Quels sont les aspects du RSI qui ont été les plus polémiques et difficiles à négocier ? Y a-t-il eu un moment de polarisation entre les pays ou régions au cours des négociations?

14.La portée plus large du RSI, le fait qu'il est appliqué aux événements de santé publique quel qu'en soit l'origine et la source a été un grand changement pour la surveillance en santé publique. La plupart des États étaient-ils d'accord pour élargir le champ d'application du RSI à cette mesure? Comment la France a-t-elle vu cet élargissement?

15.Considérez-vous la création du concept "urgence de santé publique de portée internationale" comme un progrès, à l'égard de la sécurité sanitaire internationale?

16.Quels sont les États qui ont joué un rôle déterminant pour la définition de ce concept? Lesquels ont proposé cette définition?

17.Quels sont les États qui ont vraiment supporté la mise en place du polémique antique 41 sur le partage d'informations en cas de dissémination intentionnelle d'agents chimiques, biologiques et nucléaire? Quelle a été la position de la délégation française (ou l'EU) à ce sujet? Pourquoi, à la fin, les États ont-ils décidé de retirer ce dispositif? 


\section{Bibliografia}

AMORIN, C. et al. Oslo Ministerial Declaration - global health: a pressing foreign policy issue of our time . Health Policy. Vol 369, No.9570, p.1373-1378, Abril 2007

AUSTIN, J.L. How to do things with words. Reino Unido: Oxford University Press, 1962.

ABRAHAM, Thomas. The Chronicle of a Disease Foretold: Pandemic H1N1 and the construction of Global Health Security Threat . Political Studies, Reino Unido, Vol 59, p.797 - 812, 2011

ALDIS, William. Health security as a public health concept: a critical analysis. Health Policy and Plan, Oxford Journals, Reuno Unido Vol 23, p.369 - 375, 2008

BALZACQ, Thierry. The Three Faces of Securitization: Political Agency, Audience and Context . European Journal of International Relations, Reuno Unido, Vol 11, p171 - 193, junho 2005

BAKANIDZE, Lela, IMNADZE, Paata, PERKINS, Dana. Biosafety and biosecurity as essential pillars of international health security and cross-cutting elements of biological nonproliferation. BMC Public Health, Vol 10 (Suppl1), 2010

BAKER, Michael G, FIDLER, David P. Global Public Health Surveillance under New International Health Regulations. Emerging Infectious Diseases Journal, Estados Unidos, Vol 12(7), p. 1058-1065, Julho 2006.

BAKER, Michael G, FORSYTH, Andrew M. The new International Health Regulations: a revolutionary change in global health security. The New Zealand Medical Journal, Nova Zelândia,Vol 120 N.1267. Dezembro 2007,

BASTY, Florence. La Sécurité Humaine: Un Renversement Conceptuel pour les Relations Internationales . Raisons Politiques, França, Vol. 4 N.32, p.35-57, 2008.

BERNARD, Phillips. Entrevistas, Questionários e Levantamentos. In: Pesquisa Social: estratégias e táticas. Rio de Janeiro: Agir, 1974

BIGO, Didier. When Two Become One: Internal and External Securitisations in Europe. In. International Relations Theory and The Politics of European Integration. Power, Security and Community. ed. / Morten Kelstrup; Michael Williams. Routledge, p. 171 - 204. 2000

. Security and Immigration: Toward a Critique of the Governmentally of Unease .Alternatives Vol. 27, p.63-92, 2002

BOOTH, Ken. Critical Explorations. In BOOTH, Ken (ed) Critical Security Studies and World Politics. London: Lynner Rienner, 2004

Theory of World Security. Cambridge: Cambridge University Press.,2007

BURCI, Gian Luca, KOSKENMAKI, Riikka. Human Rights Implication of Governance Responses to Public Health Emergencies: The Case of Major Infectious Disease Outbreaks. In Andrew 
Clapham e Mary Robinson (org), Realizing The Right to Health, Swiss Human Rights Books series, Suiça, Vol 3, p.346-363 2009

BURCI, Gian L. Ebola, the Security Council and the securitization of public health. Questions of International Law. p. 27-39, Dezembro 2014. Disponível em http://www.qil-qdi.org/ebola-securitycouncil-securitization-public-health/

BUZAN, Barry; WAEVER, Ole; WILDE, Jaap. Security: a new framework for analysis. London: Lynne Rienner, 1998

CABALLERO-ANTHONY, Mely; AMUL, Giane G. Health and human security: Pathways to advancing an human centered approach to health security in east Asia. In Routledge Handbook of Global Health Security. Edited by. RUSHTON \& YOUDE. New York: Routledge, 2015

DAVIES, Sara E. Securitizing Infectious Disease. International Affairs, Vol. 84(2), p.295-313 2008

DAVIES, Sara; SCOTT, Adam; RUSHTON, Simon. Disease Diplomacy: International Norms and Global Health Security. Estados Unidos: Johns Hopkins University Press.. 2015

DAVIS, Christopher. Nuclear Blindness: An Overview of the Biological Weapons Programs of the Former Soviet Union and Iraq. Emerging Infectious Diseases Journal, Vol 5, N.4, 1999. http:// wwwnc.cdc.gov/eid/article/5/4/99-0408_article

ELBE, Stefan. Should HIV/AIDS be securitized? The ethical dilemmas of linking HIV/AIDS and security. International Studies Quarterly, Vol 50 (1). pp. 119-144, 2006

. Haggling over viruses: the downside risks of securitizing infectious disease. Health Policy and Plan, Reino Unido: Oxford Journals, Vol5, p.476-485, 2010

. Pandemic on the radar screen: health security, infectious disease and the medicalization of insecurity . Political Studies, Vol 59, p. 848-866, 2011.

ENEMARK, Christian. Disease and Security: Natural plagues and biological weapons in East Asia. Abingdon: Routledge, 2007

FIDLER, David P, GOSTIN, Lawrence O. The New International Health Regulations: An Historic Development for International Law and Public Health. Journal of Law, medicine \& Etics. Vol. 34 p. 85-94, Primavera 2006

Biosecurity in the Global Age: Biological Weapons, Public Health and The rule of Law. California: Stanford. 2008

FIDLER, David P. Public Health and National Security in Global Age: Infectious Disease, Bioterrorism, and Realpolitik. Corydon: Indiana University: Faculty Publications, Paper 416, 2003

. Constitutional Outlines of Public Health's New Order. Indiana University: Faculty Publications, Paper 401, 2004. Disponível em: http://www.repository.law.indiana.edu/cgi/viewcontent.cgi? article $=1403 \&$ context $=$ facp $u b$ 
. From International Sanitary Conventions to Global Health Security: The New International Health Regulations. Chinese Journal of International Law, Oxford Journals Vol 4, N. 2, p. 325-392, 2005

. A Pathology of Public Health Securitism: Approaching Pandemics as Security Threats. In Governing Global Health: Challenge, response and Innovation. Edited by Andrew F Cooper, John Kirton and Ted Schrecker. Aldershot ; Burlington. 2007

. The Challenges of Global Health Governance. The Council on Foreign Relations (CFR). Council on Foreign Relations Press, Estados Unidos, Maio 2010. Disponível em: http:// www.cfr.org/global-governance/challenges-global-health-governance/p22202

. The Ebola outbreak and the future of global health security. In. Global Health Security: the wider lessons from the West African Ebola viruses disease epidemic. The Lancet, Reino Unido, vol 385, 2015

GROS, Frédéric. De la sécurité nationale à la sécurité humaine . Raisons politiques, França, N. 32, p5-8, 2008

. Le principe sécurité. Paris: Gallimard, 2012

FLOYD, Rita. When Foucault met security studies: A critique of the ' Paris School' of security studies. Paper apresentado na conferência anual BISA, Universidade de Cork, Irlanda, Dezembro 2006

. Human Security and the Copenhagen School's Securitization Approach: Conceptualizing Human Security as a Securitizing Move. Human Security Journal. Vol, 5, p.38-49, 2007

GOSTIN, Lawrence O.; DeBARTOLO, Mary C.;FRIEDMAN, Eric A. The International Health Regulations 10 years on: the governing framework for global health security. The Lancet, Vol. 386: P.2222-6, 2015

HANRIEDER, Tine; KREUDER-SONNEN, Christian. Who decides on the exception? Securitization and Emergency Governancy in Global Health. Security Dialogue, Vol. 45, p. 331-48, 2014.

INGLESBY, T et al. Anthrax as a Biological Weapon, 2002: Updated Recommendations for Management. JAMA. Vol.287(17), p.2236-2252, 2002

KAMRADT-SCOTT, Adam 2010. The Who Secretariat, Norm Entrepreneurship, and Global Disease Outbreak Control. Journal of International Organization Studies, Vol.1, p.72-89, 2010

KELLE, Alexander. Securitization of the International Public Health - Implications for Global Health Governance and the Biological Weapons Prohibition Regime. Global Governance, Vol. 13, No. 2, p. 217-235, 2007

LEE, Jong-Wha; MCKIBBIN, Warwick. Estimating the Global Economic Costs of SARS. In Learning from SARS: Preparing for the Next Disease Outbreak. Institute of Medicine (US) Forum on Microbial Threats Ed. KNOBLER, S. et al. Washington: National Academia Press; 2004

KRAUSE, Keith; WILLIAMS, Michael C. Broadening the Agenda of Security Studies: Politics and Methods. Mershon International Studies Review, Oct.1996 Vol 40, No2 , p 229-254, Oct.1996. 
KRAUSE, Keith; WILLIAMS, Michael C (ed). Critical Security Studies, London: UCL Press, 1997.

LO YUK-PING, Catherine. THOMAS, Nicolas. How is health a security issue? Politics, responses and issues . Health and Policy Plan, Vol, 25 p.447-453, 2010

MACLEAN, Sandra. Microbes, Mad Cows and Militaries: Exploring the Links Between Health and Security. Security Dialogue, Vol 39 (5) p.475-494, 2008

MCDONALD, Matt. Securitisation and the Construction of Security. European Journal of International Relations. Vol, 14, N.4, p. 563-587, 2008

MCINNES, Colin; RUSHTON, Simon. HIV/AIDS and securitization theory. European Journal of International Relations, vol.19, p. 115 - 138, Janeiro 2012

MCINNES, Colin; LEE, Kelley. Global Health and International Relations. Cambridge: Polity Press, 2012

MCINNCES, Colin. The many meanings of security. In Routledge Handbook of Global Health Security. Edited by RUSHTON \& YOUDE. Routledge New York, 2015

MUSUMECI, Martino G. Semiótica das securitizações governamentais na América do Sul contemporânea: construção das significações de segurança e defesa em documentos políticos da região. 2011 Dissertação (Mestrado em Ciência Política) - Faculdade de Filosofia Letras e Ciências Humanas da USP - SP

NUNES, João. Health, Politics and Security. Politics and International Studies, University of Warwick. E-cadernos CES, Vol. 15, p.142-164, 2012

. Security, Emancipation and Politics of Health: a New Theoretical Perspective. Abingdon: Routledge 2013

. The politics of health security. In Routledge Handbook of Global Health Security. Edited by RUSHTON \& YOUDE. Routledge New York 2015

PORTELA, Paulo Henrique Gonçalves. Direito internacional Público e Privado. 2 ed. Bahia: Podivm, 2010. p.75

ROEMER-MAHLER, Anne; ELBE, Stefan. The race for Ebola drugs: pharmaceuticals, security and global health governance. The Third World Quarterly, Vol, 37 N.3, p. 487-506. 2016, Disponível em: http://dx.doi.org/10.1080/01436597.2015.1111136

RUSHTON, Simon. Global Health Security: for whom? Security from what?. Political Studies, Vol 59, p.779-796, 2011

SILVA, G. et al. Defesa química: histórico, classificação dos agentes de guerra e ação dos neurotóxicos. Quím. Nova, São Paulo, v. 35, n. 10, p. 2084, 2012 
TUCKER, Jonathan B. Updating the International Health Regulations. Biosecurity and Bioterrorism: Biodefense Strategy, Practice, and Science. Volume 3, No. 4, p.338-347, 2005

VENTURA, Deisy. Direito e Saúde Global: $O$ caso da pandemia de gripe A(H1N1). Sao Paulo: Outras Expressões, Dobra Editorial, 2013.

. Do Ebola ao Zika: as emergências internacionais e a securitização da saúde global. $C a$ dernos de Saúde Pública, Rio de Janeiro, Vol, 32(4), abril 2016

YOUDE, Jeremy. Mediating Risk through the International Health Regulations and Bio-political surveillance. Political Studies, Vol 59, p. 813-830, 2011

ZYLBERMAN, Patrick. Crises Sanitaires, Crises Politiques. Les Tribunes de la santé, França N. 34, p35-50, 2012

WAEVER, Ole. Securitization and Desecuritization. In: LIPSCHUTZ, Ronnie D. On Security, New York: Columbia, 1995.

Aberystwyth, Paris, Copenhagen New 'Schools' in Security Theory and their Origins between Core and Periphery. Paper apresentado na reunião anual do International Studies Association, Montreal, Março , 2004

WEIR, Lorna; MYKHALOVSKIY. Global Public Health Vigilance: Creating a World on Alert. Abingdon: Routledge, 2010.

WEIR, Lorna. Inventing Global Health Security, 1994-2005. In Routledge Handbook of Global Health Security. Edited by RUSHTON \& YOUDE. Routledge New York 2015

\section{Documentos:}

Agência Internacional de Energia Atômica (AIEA). Convention on the Physical Protection of Nuclear Material. Viena 1979. Disponivel em: https://www.iaea.org/publications/documents/conventions/convention-physical-protection-nuclear-material

Agência Nacional de Vigilância Sanitária (ANVISA) 2009. Regulamento Sanitário Internacional - RSI 2005. Versão em português aprovada pelo Congresso Nacional por meio do Decreto Legislativo 395/2009. Disponível em: http://www.anvisa.gov.br/hotsite/viajante/Regulamento_Sanitario_Internacional_versão\%20para\%20impressão.pdf

Ata de Buenos Aires, (ATA DE BUENOS AIRES) 2005. Seminario de Revision del Reglamento Sanitario Internacional de los Paises del Area Andina y Mercosur. Abril 2005

Comunidade Europeia, (COMUNIDADE EUROPEIA) 2004. Preliminary comments of the European Community and its Member States on the draft-revised of the International Health Regulations. Maio de 2004. 
Consenso de Montevidéu, (CONSENSO DE MONTEVIDÉU) 2005. Consideraciones y puntos de consenso entre los Estados de Argentina, Bolivia, Brasil, Chile, Ecuador, Paraguay, Perú, Uruguay y Venezuela en relación al Documento A/HIR/IGWG/2/2. 24 de enero de 2005

Estados Unidos (EUA), 2002. The National Strategy for Homeland Security. US Department of Homeland Security. Disponível em: https://www.dhs.gov/sites/default/files/publications/nat-strathls-2002.pdf

. 2002a. Public Health Security and Bioterrorism Preparedness and Response Act. US Food and DrugAdministration. Disponível em: http://www.fda.gov/RegulatoryInformation/Legislation/ucm 155733.htm

2004. Initial U.S Government Comments on the Frist Draft of the Proposed Revisions of the IHR, março. Genebra: OMS.

. 2005. A58/4. Statement for the record by the Government of the United States of America concerning the World Health Organization's revised International Health Regulations. Maio, 2005. Documento não disponível online.

. 2004a. Second U.S Government Comments on the Frist Draft of the Proposed Revisions of the IHR, Genebra: OMS.

Institute of Medicine (IOM) 1992. Emerging Infectious: Microbial Threats to Health in the United States. (Ed) LEDERBERG, J.; SHOPE, R. Estados Unidos: National Academia Press

Japão, (JAPAO) 2004. Japan's comments on the first draft of the proposed revision of the International Health Regulations (IHR), 9 de julho de 2004: http:/www.who.int/ihr/revisionprocess/japan2004_09_15.pdf?ua=1

Mexico (MEXICO), 2004. General Comments by Mexico on the Draft International Health Regulations. 30 de junho de 2004

Noruega (NORUEGA), 2004. The Royal Ministry of Health. 2004

Organização Mundial da Saúde (OMS). 1969. WHA 22.46, International Health Regulations (1969). Genebra: OMS

. 1946. World Health Constitution, Genebra: OMS. Disponível em: http://www.who.int/ governance/eb/who_constitution_en.pdf 1998.

1995. WHA 48.13 Communicable Disease Prevention and Control: New, Emerging, and Re-emerging Infectious Disease, Genebra: OMS. Disponível em: http://apps.who.int/iris/bitstream/ 10665/178421/1/WHA48 R13 eng.pdf bra: OMS

.1995a WHA 48.7. Revision and Updating of the International Health Regulations. Gene-

1999. A52/9. Revision and updating of the International Health Regulations: progress report. Report by the Secretariat Genebra: OMS. 
. (2000).Weekly Epidemiological Record (WER). N.4, 28 de Janeiro, 2000 Genebra: OMS. Disponível em: http://www.who.int/wer/en/

. 2000a. A framework for global outbreak and alert and response. Genebra: OMS. Disponível em: http://www.who.int/csr/resources/publications/surveillance/whocdscsr2002.pdf

. 2001. WHA 54.14. Global Health Security - epidemic alert and response, Report by the Secretariat. Genebra: OMS

2001a. WHO. Public health response to biological and chemical weapons - WHO guidance. [Pre-publication issue]. Genebra: OMS. Documento não disponível online.

. 2001b. EB 109/26. The deliberate use of biological and chemical agentes to cause harm: public health response. Genebra: OMS

Disponível: http://apps.who.int/gb/archive/pdf_files/EB109/eeb10926.pdf

2001c. EB 107/INF.DOC./7. Global Health Security - epidemic alert and response: Revision of the International Health Regulations. Genebra: OMS. Documento disponível em: http:// apps.who.int/gb/archive/pdf_files/EB107/eeid7.pdf

. 2002. WHO. Global Crises - Global Solutions: Managing public health emergencies of international concern through the revised International Health Regulations, Genebra: OMS.

2002a. EB109.R5. Global public health response to the deliberate use of biological and chemical agents, and radio-nuclear attacks to cause harm.

Genebra: OMS. Disponível em: http://apps.who.int/iris/bitstream/10665/78430/1/eeb109r5.pdf? ua $=1$

. 2002b. WHA55.16. Global public health response to natural occurrence, accidental release or deliberate use of biological and chemical agents or radionuclear material that affect health. Genebra: OMS. Disponível em: http://apps.who.int/gb/archive/pdf_files/WHA55/ewha5516.pdf? ua $=1$

.2002c. A55/20. Deliberate use of biological and chemical agents to cause harm. Raport by the Secretariat. Genebra: OMS. Disponível em: http://apps.who.int/iris/bitstream/10665/78476/1/ ea5520.pdf

. 2002d. Weekly Epidemiological Record (WER). N. 19, 10 de maio, 2002. Genebra: OMS

.2003. WHO, Global defense against the infectious disease threat, Genebra: OMS. Disponível em: http://whqlibdoc.who.int/publications/2003/9241590297.pdf

. 2003a. WHA 56.28. Revision of the International Health Regulations, Genebra: OMS.

Disponível em: http://apps.who.int/gb/archive/pdf_files/WHA56/ea56r28.pdf?ua=1

.2003b. WHA 56.29. Severe Acute Respiratory Syndrome (SARS). Genebra: OMS. Disponível: http://www.who.int/csr/sars/en/ea56r29.pdf

.2003c. A56/48. SARS and the revision of IHR. Report by the Secretariat Genera: OMS. Disponível: http://www.who.int/csr/sars/WHA56-48.pdf 
. 2003d. A56/25.Revision of the IHR. Report by the Secretariat. Genebra: OMS: Disponível em http://apps.who.int/gb/archive/pdf_files/WHA56/ea5625.pdf

. 2003e. WHO Framework Convention on Tabacco Control. Genebra: OMS. Disponível em: http://apps.who.int/iris/bitstream/10665/42811/1/9241591013.pdf?ua=1

. 2003f. World Health Report 2003: Shaping the Future. Genebra OMS. Disponível em: http://www.who.int/whr/2003/en/whr03 en.pdf?ua=1

. 2004. IGWG/IHR/Working paper. International Health Regulations - Working Paper for Regional Consultations. Genebra: OMS.

Disponível em : http://www.who.int/csr/resources/publications/IGWG_IHR_WP12_03-en.pdf

. 2004a. EB113/3 Rev.1. Revision on the International Health Regulations. Report by the Secretariat. Genebra: OMS

Disponível em: http://apps.who.int/gb/archive/pdf_files/EB113/eeb1133r1.pdf

. 2004b. A/IHR/IGWG/3. Review and approval of proposed amendments to the International Health Regulations: draft revision. Genebra: OMS http://apps.who.int/gb/ghs/pdf/ A_IHR_IGWG_3-en.pdf

.2004c. A/IHR/IGWG/2. Summary of Regional Consultations. Genebra: OMS. Disponível: http://apps.who.int/gb/ghs/pdf/IHR_IGWG_2-en.pdf

.2004d. Comments of the International Atomic Energy Agency on the draft revised International health Regulations of the WHO. Genebra: OMS. Disponível em: http://www.who.int/ihr/iaea2004_11_09.pdf?ua=1

. 2004e. A/IHR/IGWG/A/Conf.paperNo.2. Review and approval of proposed amendments to the international Health Regulations. Genebra: OMS. Documento não disponível online.

. 2004f. A/IHR/IGWG/INF.DOC.1. Review and approval of proposed amendments to the International Health Regulations: relations with other international instruments. Genebra: OMS

. 2005. WHA58.3, Revision of the International Health Regulations, WHA58.3, Genebra: OMS. Disponível em: http://www.who.int/csr/ihr/WHA58-en.pdf

. 2005a. A/IHR/IGWG/2/2. Review and approval of proposed amendments to the International Health Regulations, Proposal by the Chair, Genebra: OMS. Disponível em: http://apps.who.int/ gb/ghs/pdf/IHR_IGWG2_2-en.pdf

2005b. IHR/IGWG/I/SR/1. Provisional Summary Record of the First Meeting. Genebra: OMS. Documento não disponível online

. 2005c. A/IHR/IGWG/2/Conf.Paper No.6. Review and approval of proposed amendments to the International Health Regulations - Conference Paper indicating progress as of Thursday evening. OMS: Genebra, 24 de fevereiro 2005. Documento não disponível online.

2007. A Safer future: global public health security in the 21 st century. The World Health Report. Disponível em: http://www.who.int/whr/2007/en/ 
2015. A68/22 Add1. Implementation of the International Health Regulations. Report of the Review Committee on the Second Extensions for Establishing National Public Health Capacities and on IHR Implementation. OMS: Genebra. Março 2015. Disponível em: http://apps.who.int/ gb/ebwha/pdf files/WHA68/A68_22Add1-en.pdf

. 2015b. Report of the Ebola Interim Assessment Panel. Genebra: OMS. DisponÍVEL EM: http://www.who.int/csr/resources/publications/ebola/report-by-panel.pdf

. 2016. A69/20. Implementation of the International Health Regulations (2005). Annual report on the implementation of the International Health Regulations (2005). Report by the Director-General. Genebra: OMS

.2016b. A69/21. Report of the Review Committee on the Role of the International Health Regulations (2005) in the Ebola Outbreak Response. Genebra: OMS. Disponível em: http:// apps.who.int/gb/ebwha/pdf files/WHA69/A69 21-en.pdf?ua $=1$

. 2016c. Statement on the 9th meeting of the IHR Emergency Committee regarding the Ebola outbreak in West Africa. Genebra: OMS Disponível em: http://www.who.int/mediacentre/ news/statements/2016/end-of-ebola-pheic/en/

Organização das Nações Unidas (ONU). 1945. Carta das Nações Unidas e Estatuto da Corte Internacional de Justiça. Nações Unidas. Documento disponível em: http://unicrio.org.br/img/Cartada$\underline{\text { ONU VersoInternet.pdf }}$

. 2000. Conselho de Segurança. Resolução 1308. UN Security Council Resolution 1308 (2000) on the Responsibility of the Security Council in the Maintenance of International Peace and Security: HIV/AIDS and International Peace-keeping Operations. Disponível: http://www.un.org/ Docs/scres/2000/sc2000.htm

2003. Human Health Security Now. Report of Commission on Human Health Security. New York; 2003. Disponível em: http://reliefweb.int/sites/reliefweb.int/files/resources/91BAEEDBA50C6907C1256D19006A9353-chs-security-may03.pdf

. 2004. A more secured world: Our shared responsibility. UN High-level Panel on Threats, Challenges and Change. Nações Unidas, 2004. Disponível em: http://www.un.org/en/peacebuilding/ pdf/historical/hlp_more_secure_world.pdf

. 2005. A/59/2005. In Larger Freedom: towards development, security and human rights for all. Report of the Secretary General. Nações Unidas. Disponível em: http://www.un.org/en/ events/pastevents/in_larger_freedom.shtml

. 2014. A/69/389-S/2014/679. Identical letters dated 17 September 2014 from the Secretary-General addressed to the President of the General Assembly and the President of the Security Council. Nações Unidas. Disponível em: http://www.securitycouncilreport.org/atf/cf/ \%7B65BFCF9B-6D27-4E9C-8CD3-CF6E4FF96FF9\%7D/S_2014 679.pdf

.2014a. S/RES/2177. Resolution 2177. Conselho de Segurança. Nações Unidas. Disponível em: http://www.ifrc.org/docs/IDRL/UN\%20SC\%20Res.pdf 
2014b. A/RES/69/1. Measures to contain and combat the recent Ebola outbreak in West Africa. Resolution adopted by the General Assembly on 19 September 2014. Assembleia Geral . Nações Unidas. Disponível em: http://www.securitycouncilreport.org/atf/cf/\%7B65BFCF9B-6D274E9C-8CD3-CF6E4FF96FF9\%7D/A_RES_69_1.pdf

. 2014c. S/PV/7268. Security Council Meeting Records. Nações Unidas. Disponível em: http://outreach.un.org/mun/files/2014/11/SPV7268 ebola.pdf

Organização Pan-Americana de Saúde (OPAS). 2004. Report of the Consultation Meeting on the Revision of the International Health for Central America, Cuba, and the Dominican Republic, 27-29 de abril de 2004, Santo Domingo:

Disponível: http://www.who.int/ihr/revisionprocess/dominicaenglish2004_09_06.pdf?ua=1

. 2004a: Report of the Consultation Meeting of the Revision of the International Health Regulations for South American Countries, Rio de Janeiro: Disponível: http://www.who.int/ihr/revisionprocess/brazil2004_09_6.pdf

.2004b: Report of the North American Consultation Meeting of the Revision of the International Health Regulations. Ottawa, Canada.

Organisation for the Prohibition of Chemical Weapons (OPCW). 1972. Chemical Weapons Convention. Disponível em: https://www.opcw.org/chemical-weapons-convention/download-the-cwc/

Programa das Nações Unidas para Desenvolvimento (PNUD) 1994. Human Development Report. New York. Disponível em: http://hdr.undp.org/sites/default/files/reports/255/hdr_1994_en_complete nostats.pdf

Regional Office for Africa (AFRO), 2004. AFR/RC54/INF/DOC.4 : Regional Consultation on The Revised Health Regulations. 22 de julho de 2004.

Regional Office for Eastern Mediterranean (EMRO), 2004. EM/RC51/6: International Health Regulations - update on the revised version. Agosto de 2004

Regional Office for Europe (EURO), 2004. European Regional Consultation on Revision of the International Health Regulations. Copenhague, junho de 2004.

Regional Office for South-East Asia (SEARO) 1998. SEA/RC51/11 Add.1. Regional Office for South-East Asia, Regional Committee , 27 de julho de 1998

Disponível em: http://repository.searo.who.int/bitstream/123456789/5318/42/rdr98_RIHR.pdf

. 2004. Report of the Second Regional Consultation on the Revised International Health Regulations. Nova Deli. Julho de 2004

. 2005. Report of the Third Regional Consultation on the Revised International Health Regulations. Janeiro 2005.

Regional Office for Western Pacific (WPRO), 2004. Consultation on the revision of The International Health Regulations in the Western Pacific Region. Manila, 28-30 abril de 2004. 